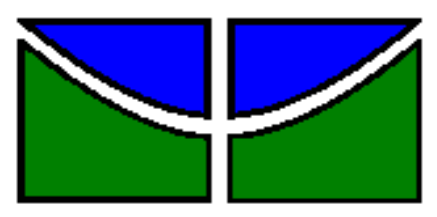

UNIVERSIDADE DE BRASÍLIA

FACULDADE DE EDUCAÇÃO

PROGRAMA DE PÓS-GRADUAÇÃO EM EDUCAÇÃO

BNCC E OS CURRÍCULOS SUBNACIONAIS: prescrições indutoras das políticas educacionais e curriculares

ALESSANDRA VALÉRIA DE PAULA

BRASÍLIA/DF

2020 
BNCC E OS CURRÍCULOS SUBNACIONAIS: prescrições indutoras das políticas educacionais e curriculares

Dissertação apresentada ao Programa de PósGraduação em Educação (PPGE/MP) da Faculdade de Educação (FE) da Universidade de Brasília/UnB como requisito para a obtenção do título de mestra em Educação. Linha de pesquisa: Gestão de Políticas e Sistemas Educacionais.

Orientador: Profo Dr. Francisco Thiago Silva.

BRASÍLIA/DF 


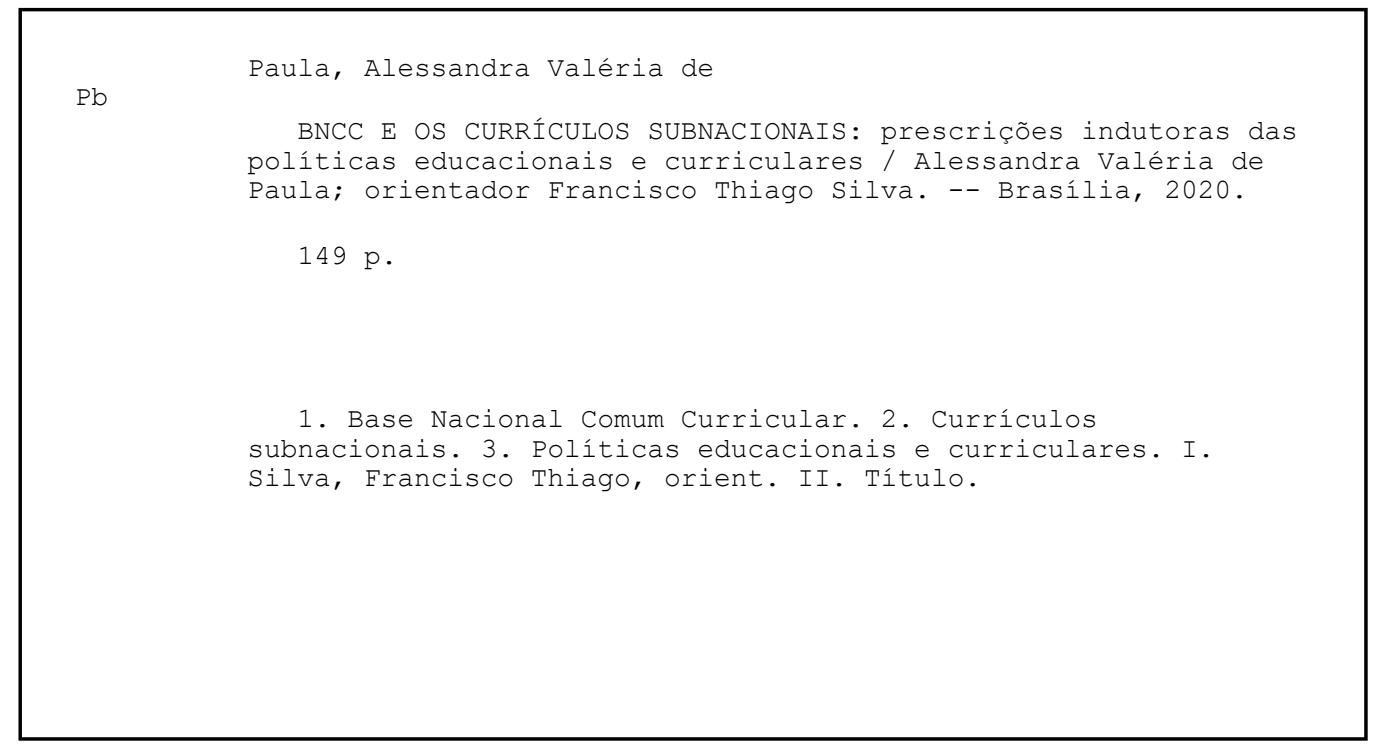




\section{BNCC E OS CURRÍCULOS SUBNACIONAIS: prescrições indutoras das políticas educacionais e curriculares}

Dissertação apresentada ao Programa de Pós-Graduação em Educação (PPGE/MP) da Faculdade de Educação (FE) da Universidade de Brasília/UnB como requisito para a obtenção do título de mestra em Educação. Linha de pesquisa: Gestão de Políticas e Sistemas Educacionais. Orientador professor Dr. Francisco Thiago Silva.

COMISSÃO JULGADORA

Prof Dr Francisco Thiago Silva Universidade de Brasília/PPGE-MP

(Presidente)

Prof ${ }^{-a}$ Dr$^{a}$ Mariana Rosa Mastrella de Andrade Universidade de Brasília/Instituto de Letras/PPGLA (Membro externo)

Prof ${ }^{a} \mathrm{Dr}^{\mathrm{a}}$ Liliane Campos Machado

Universidade de Brasília/PPGE-MP

Prof ${ }^{a}{ }^{-a} r^{a}$ Lívia Freitas Fonseca Borges

Universidade de Brasília/PPGE

(suplente)

Defesa em: 25 de junho de 2020.

Local: Campus Darcy Ribeiro, Universidade de Brasília.

(Porta de conferência: Jitsi Meet) 


\section{Dedico esta pesquisa}

À minha mãe Cida, esse "anjo torto" que tanto nos protege e fala palavrões. Ao meu pai Eroí, que me ensinou a não me sentir melhor nem pior do que ninguém, neste caso, nem mesmo com a panturrilha dilacerada no parquinho da escola aos seis anos de idade.

À minha filha Brenda, por me instar a ter confluência entre teoria e prática.

Ao meu filho Alex, meu melhor presente de aniversário desde 2000. 


\section{AGRADECIMENTOS}

Ao Deus de Amor, Beleza e Justiça, pela existência, por me habitar, por todos que caminha(ra)m comigo, pelo devir, por ligar o sol e rimar os versos e os reversos da vida.

À minha família, primeira escola. Aos meus pais, por todo zelo e dedicação. Ao Claudio, à Brenda e ao Alex, por me permitirem ser coautora da vida. Às minhas irmãs Cátia, Carla, Larice e ao meu irmão Marcos, pelo apoio a qualquer tempo, por seus cônjuges, pela sobrinha, pelos sobrinhos e pets adoráveis.

Ao Alex Bezerra Leitão, pelo incentivo inicial e generosidade constantes em prol deste mestrado.

À Secretaria de Educação do Distrito Federal pelo afastamento remunerado para estudo.

Ao meu orientador Francisco Thiago Silva, por ter-me içado no meio do dilúvio e ter sido a bússola segura de volta a terra firme.

Às professoras Mariana Rosa Mastrella-de-Andrade, Fernanda Natasha Bravo Cruz, Lívia Freitas Fonseca Borges e Liliane Campos Machado pelas preciosas leituras na qualificação e na defesa da pesquisa.

Às/Aos professoras/es da Faculdade de Educação e da SEDF que garantiram a Pedagogia Histórico-Crítica no Currículo em Movimento do DF.

Ao coordenador do PPGE/MP Profo Dr. Francisco José R. Herrera e aos servidores da secretaria, pelo trabalho de excelência e humanizado que nos dispensam.

Ao Thomaz, pelas Duetúlias.

À Júlia Ribeiro, por todo o auxílio com o pré-projeto. À Laryssa, Lêda, Sandra Campêlo, Ana Cristina, Monique, Lívia, Rosângela, Cecília, Érika, Eveline, Kellen, Edna, Juliângela, Sheley, Nilvânia, Kalinka, e ao Ibsen, Guilherme, Odilon, Aurênio, Paulo, amigas/os que conheci durante mestrado e que compartilham muito mais que pdfs.

Aos amigos da resistência Wendel, Isaías, Lúcia, Fabiano, Izabella Gobbi, Sr. Antônio e Loreley, por termos juntos democratizado a democracia e garantido a inclusão rasgadas na escola, o que me impeliu a estudar mais.

Aos brothers Marquim\&Digar e à Eliane, por nossa amizade ter resistido às minhas ausências antes mesmo da COVID-19.

À Carmem Corrêa Miranda, pela formatação e auxílio com as normas da ABNT. 
A única finalidade da ciência consiste em buscar aliviar a miséria da existência humana

Bertold Brecht 
PAULA, Alessandra Valéria de. BNCC e os currículos subnacionais: prescrições indutoras das políticas educacionais e curriculares. 2020. $150 \mathrm{f}$. Dissertação (Mestrado em Educação) - Universidade de Brasília, Brasília, DF, 2020.

\section{RESUMO}

A presente pesquisa analisou as relações estabelecidas entre a Base Nacional Comum Curricular (BNCC) e os currículos subnacionais, compreendendo que esse encontro é o ponto de partida para as políticas educacionais e curriculares. Nesse contexto, analisamos a forma pela qual as Unidades da Federação atualizaram seus currículos à luz da BNCC. Discutimos a premência de um núcleo comum, averiguamos se os estados e o Distrito Federal absorveram a Base como prescrição ou orientação, identificamos os pressupostos teórico-epistemológicos que sustentam as propostas curriculares e estimamos o grau de adesão dos currículos à BNCC. Pautamo-nos em constructos teórico-metodológicos da pesquisa qualitativa e nas estratégias de revisão bibliográfica e análise documental para a construção dos dados. Procedemos à observação do fenômeno sob o influxo conceitual da Sociologia Política da Ação Pública de Lascoumes e Le Galès (2012), e das concepções críticas de educação e de currículo, principalmente, em Saviani (2007, 2012, 2013), Freitas (2002, 2018), Sacristán (2000, 2011), Santomé (2011), Silva (2002), Silva F. $(2018,2020)$ e Borges (2014). As análises dos dados ocorreram por meio da Análise de Conteúdo de Bardin (2009), e os resultados revelaram que, pelo menos em nível prescrito, a Base é uma abundância normativa, que a profusão conceptual e os equívocos teórico-epistemológicos da Base se reproduzem nos documentos subnacionais, os quais, contudo, em sua maioria, a absorveram como orientação e demonstram baixo grau de adesão à BNCC. Ressaltamos a urgência de estudos no campo curricular e em teoria do conhecimento que permitam avanços em relação ao desenvolvimento dessa reforma, que incide em todos os mecanismos da prática escolar. $O$ produto técnico da pesquisa é um curso em nível de pósgraduação lato sensu intitulado: Base Nacional Comum Curricular e a Organização do Trabalho Pedagógico.

Palavras-chave: Base Nacional Comum Curricular. Currículos subnacionais. Políticas educacionais e curriculares. 
PAULA, Alessandra Valéria de. BNCC e os currículos subnacionais: prescrições indutoras das políticas educacionais e curriculares. 2020. $150 \mathrm{f}$. Dissertação (Mestrado em Educação) - Universidade de Brasília, Brasília, DF, 2020.

\begin{abstract}
This research analyzed the relations established between the Brazilian National Core Curriculum (BNCC) and the subnational curricula, understanding that this confluence is the starting point for educational and curricular policies. In this context we analyzed how the units of the Federation updated their curricula in the light of the BNCC. We discussed the urgency of a common core, we examined whether the states and the Federal District absorbed the Base as ordinance or orientation, we identified the theoretical-epistemological assumptions that support the curricular proposals, and we estimated the degree of adherence of the curricula to the BNCC. We were guided by theoretical-methodological constructs of qualitative research and strategies of bibliographic review and document analysis for the construction of data. We proceeded to observe the phenomenon under the conceptual influence of the Political Sociology of Public Action by Lascoumes and Le Galès (2012), and the critical conceptions of education and curriculum, mainly in Saviani (2007, 2012, 2013), Freitas (2002, 2018), Sacristán (2000, 2011), Santomé (2011), Silva (2002), Silva F. $(2018,2020)$ and Borges (2014). The data analyses took place through Content Analysis in Bardin (2009), and the results revealed that, at least in the prescribed level, the Base is a normative abundance, that the conceptual profusion and theoretical-epistemological inaccuracies of the Base are reproduced within the subnational documents, which, however, mostly absorbed it as a guideline, and demonstrate a low degree of adhesion to the BNCC. We emphasize the urgency of studies in the curricular field and in the theory of knowledge that may allow advances in relation to the development of this reform, which affects all the mechanisms of school practice. The technical product of the research is a postgraduate lato sensu level course entitled: Common National Curricular Base and the Organization of Pedagogical Work.
\end{abstract}

Keywords: Common National Curricular Base. Subnational curricula. Educational and curricular policies. 


\section{LISTA DE QUADROS}

Quadro 1 - Proposta de matriz curricular de Pós-Gradução em latu sensu Módulo I - Metodologia da pesquisa em educação - 40h

Quadro 2 - Proposta de matriz curricular de Pós-Gradução em latu sensu Módulo II - Teorias de educação e concepções pedagógicas - 45h ...26

Quadro 3 - Proposta de matriz curricular de Pós-Gradução em latu sensu Módulo III - Teorias de concepções curriculares - 45h .......................27

Quadro 4 - Proposta de matriz curricular de Pós-Gradução em latu sensu Módulo IV - BNCC: fundamentos e processos - 35h

Quadro 5 - Proposta de matriz curricular de Pós-Gradução em latu sensu Módulo V - BNCC da Educação Infantil - 35h.

Quadro 6 - Proposta de matriz curricular de Pós-Gradução em latu sensu Módulo VI - BNCC do Ensino Fundamental-35h

Quadro 7 - Proposta de matriz curricular de Pós-Gradução em latu sensu Módulo VII - BNCC do Ensino Médio - 45h

Quadro 8 - Proposta de matriz curricular de Pós-Gradução em latu sensu Módulo VIII - Organização do trabalho pedagógico - 35h.

Quadro 9 - Proposta de matriz curricular de Pós-Gradução em latu sensu Módulo IX - Curículo integrado e escola de tempo integral - 35h ........32

Quadro 10 - Proposta de matriz curricular de Pós-Gradução em latu sensuMódulo X - Curículo integrado e escola de tempo integral - 30h

Quadro 11 - Proposta de matriz curricular de Pós-Gradução em latu sensuMódulo XI - Profissionalidade, docência e formação curricular - 35h.33

Quadro 12 - Proposta de matriz curricular de Pós-Gradução em latu sensu Módulo XII - Oficina prática de construção curricular - 35h ..................33

Quadro 13 - Quadro de coerência da pesquisa ...................................................35

Quadro 14 - Síntese teórico-metodológica das dissertações e teses.......................43

Quadro 15 - Palavras-chave nas categorias analíticas .......................................45

Quadro 16 - Posicionamento sobre a BNCC/EM enviada pelo MEC .....................65

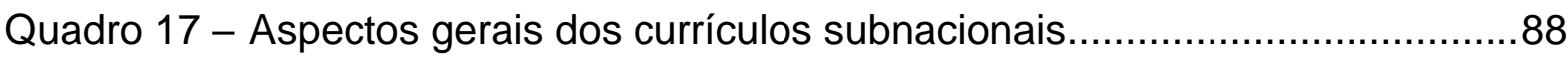

Quadro 18 - Temas favoráveis à prescrição/orientação .....................................106

Quadro 19 - Grau de adesão à BNCC ....................................................112

Quadro 20 - Aprovação dos currículos subnacionais .......................................135

Quadro 21 - Organizador curricular ..........................................................136 


\section{LISTA DE SIGLAS E ABREVIATURAS}

AbdC Associação Brasileira de Currículo

AC

Acre

ADE

Arranjos de Desenvolvimento da Educação

ADI

Ações Diretas de Inconstitucionalidade

AGB

Associação de Geógrafos Brasileiros

$\mathrm{AH} / \mathrm{S}$

Altas Habilidades e Superdotação

AL

Alagoas

AM

Amazonas

ANEE

Alunos com Necessidades Educacionais Especiais

ANFORE

Associação Nacional pela Formação dos Profissionais da Educação

ANPED Associação Nacional de Pós-Graduação e Pesquisa

AP Amapá

APEOESP Sindicato dos Professores do Ensino Oficial do Estado de São Paulo

BA Bahia

BDTD/IBICT Biblioteca Digital Brasileira de Teses e Dissertações do Instituto Brasileiro de Informação em Ciência e Tecnologia

BM Banco Mundial

BNC-Formação Base Nacional Comum para a Formação Inicial de Professores da Educação Básica

BNCC Base Nacional Comum Curricular

BNCC El/EF Base Nacional Comum Curricular da Educação Infantil e do Ensino Fundamental

BNCC EM Base Nacional Comum Curricular do Ensino Médio

CAPES Coordenação de Aperfeiçoamento de Pessoal de Nível Superior

CE Ceará

CE Conselho de Educação

CEDF Conselho de Educação do Distrito Federal 


\begin{tabular}{|c|c|}
\hline CEE-RJ & Conselho Estadual de Educação do Rio de Janeiro \\
\hline CENPEC & $\begin{array}{l}\text { Centro de Estudos e Pesquisas em Educação, Cultura e Ação } \\
\text { Comunitária }\end{array}$ \\
\hline $\mathrm{CF}$ & Constituição Federal \\
\hline $\mathrm{CIL}$ & Centro Interescolar de Línguas \\
\hline CNE & Conselho Nacional de Educação \\
\hline CONSED & Conselho Nacional dos Secretários de Educação \\
\hline DF & Distrito Federal \\
\hline DNC & Diretrizes Curriculares Nacionais \\
\hline EF & Ensino Fundamental \\
\hline $\mathrm{El}$ & Educação Infantil \\
\hline EJA & Educação de Jovens e Adultos \\
\hline ENEM & Exame Nacional do Ensino Médio \\
\hline ES & Espírito Santo \\
\hline FEDF & Fundação Educacional do Distrito Federal \\
\hline FENEP & Federação Nacional das Escolas Particulares \\
\hline FE/UnB & Faculdade de Educação da Universidade de Brasília \\
\hline $\mathrm{FHC}$ & Fernando Henrique Cardoso \\
\hline FUNDEB & $\begin{array}{l}\text { Fundo de Manutenção e Desenvolvimento da Educação Básica e } \\
\text { de Valorização dos Profissionais da Educação }\end{array}$ \\
\hline FUNDEF & $\begin{array}{l}\text { Fundo de Manutenção e Desenvolvimento do Ensino Fundamental } \\
\text { e de Valorização do Magistério }\end{array}$ \\
\hline GERM & Global Education Reform Movement \\
\hline GO & Goiás \\
\hline IFB & Instituto Federal Baiano \\
\hline IST & Infecções Sexualmente Transmissíveis \\
\hline LDB & Lei de Diretrizes e Bases \\
\hline LDBEN & Lei de Diretrizes e Bases da Educação Nacional \\
\hline LLECE & $\begin{array}{l}\text { Laboratório Latino-americano de Avaliação da Qualidade da } \\
\text { Educação para a América }\end{array}$ \\
\hline Mt & Maranhão \\
\hline
\end{tabular}




\begin{tabular}{|c|c|}
\hline MEC & Ministério da Educação \\
\hline$M G$ & Minas Gerais \\
\hline MS & Mato Grosso do Sul \\
\hline MT & Mato Grosso \\
\hline NSE & Nova Sociologia da Educação \\
\hline OCDE & Organização para a Cooperação e Desenvolvimento Econômico \\
\hline OTP & Organização do Trabalho Pedagógico \\
\hline PA & Pará \\
\hline PB & Paraíba \\
\hline PCN & Parâmetros Curriculares Nacionais \\
\hline PE & Pernambuco \\
\hline $\mathrm{PI}$ & Piauí \\
\hline Pisa & Programa Internacional de Avaliação de Alunos \\
\hline PNAIC & Pacto Nacional pela Alfabetização na Idade Certa \\
\hline PNC & Parâmetros Curriculares Nacionais \\
\hline PNE & Plano Nacional de Educação \\
\hline PNEEPEI & $\begin{array}{l}\text { Política Nacional de Educação Especial na Perspectiva da } \\
\text { Educação Inclusiva }\end{array}$ \\
\hline PNLD & Programa Nacional do Livro e do Material Didático \\
\hline PNUD & Programa das Nações Unidas para o Desenvolvimento \\
\hline PPP & Projeto Político Pedagógico \\
\hline PR & Paraná \\
\hline ProBNCC & $\begin{array}{l}\text { Programa de Apoio à Implementação da Base Nacional Comum } \\
\text { Curricular }\end{array}$ \\
\hline PUC/SP & Pontifícia Universidade Católica de São Paulo \\
\hline RJ & Rio de Janeiro \\
\hline RN & Rio Grande do Norte \\
\hline RO & Rondônia \\
\hline $\mathrm{RR}$ & Roraima \\
\hline RS & Rio Grande do Sul \\
\hline Saeb & Sistema de Avaliação da Educação Básica \\
\hline
\end{tabular}


Sociedade Brasileira de Física

SBPC

Sociedade Brasileira para o Progresso da Ciência

SC

Santa Catarina

SE

Sergipe

SEDUC

Secretaria de Educação

SEDF

Secretaria de Educação do Distrito Federal

SEEDF

Secretaria de Estado de Educação do Distrito Federal

SME

Secretarias Municipais de Educação

SP

São Paulo

SRG

Sala de Recursos Generalista

STEM

Ciências, Tecnologias, Engenharias e Matemática

SUS

Sistema Único de Saúde

TEA

Transtorno do Espectro Autista

TGD

Transtorno Global do Desenvolvimento

TO

Tocantins

TST

Temas Contemporâneos Transversais

UF

Unidades da Federação

UMBRASIL União Marista do Brasil

Undime União Nacional dos Dirigentes Municipais de Educação

UNESCO Organização das Nações Unidas para a Educação, a Ciência e a Cultura

UNICEF Fundo das Nações Unidas para a Infância 


\section{SUMÁRIO}

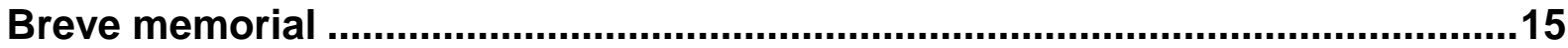

1 INTRODUÇÃO

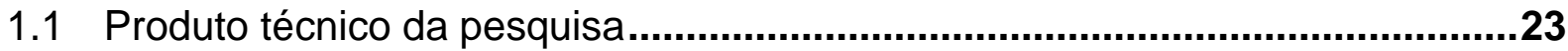

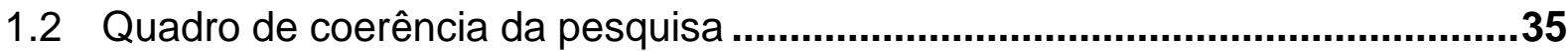

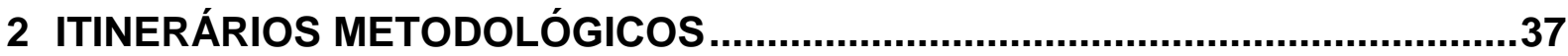

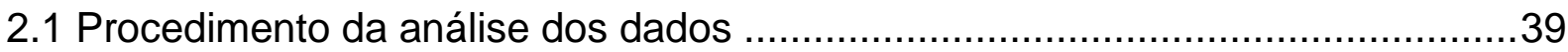

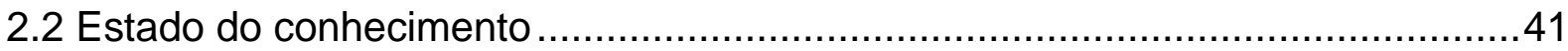

3 A COMPLEXIDADE E A MULTIATORIALIDADE DA BNCC: ELEMENTOS PARA UMA SOCIOLOGIA POLÍTICA DA AÇÃO PÚBLICA..............................50

3.1 Ambiência de normatizações e de regulamentações político-sociais...................52

3.2 Instrumentação da BNCC: arena de poder e construção de sentidos ...................60

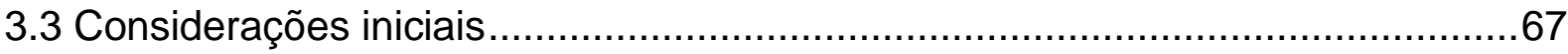

4 EPISTEMOLOGIAS EDUCACIONAIS E DE CURRÍCULO PRESENTES NOS

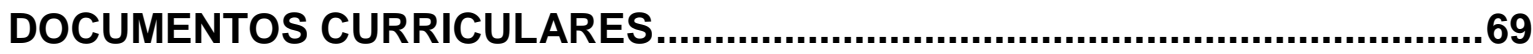

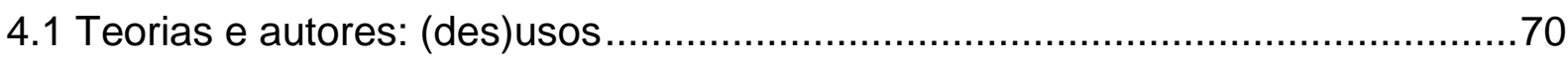

4.2 Cenário conceitual nacional com o advento da BNCC .....................................77

5 OS CURRÍCULOS SUBNACIONAIS À LUZ DA BNCC: O QUE OS DADOS

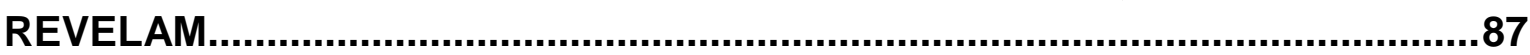

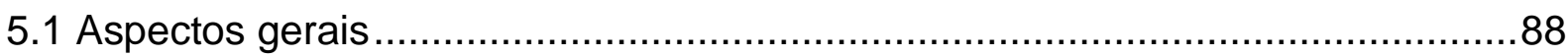

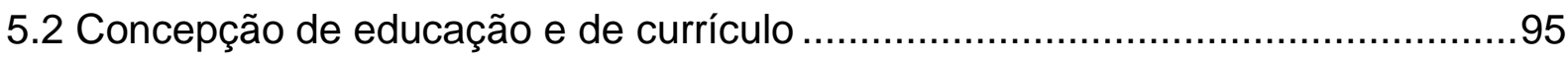

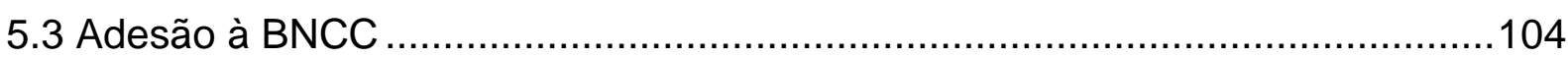

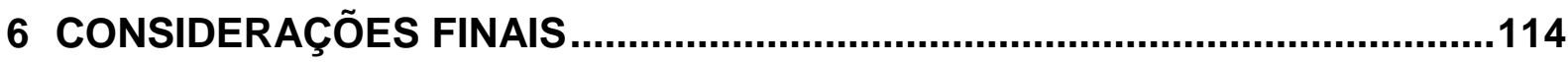

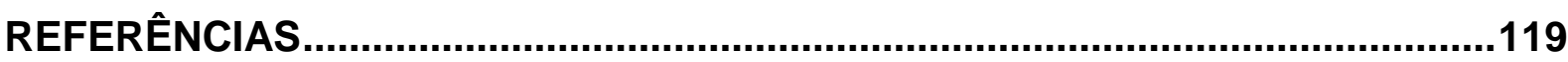

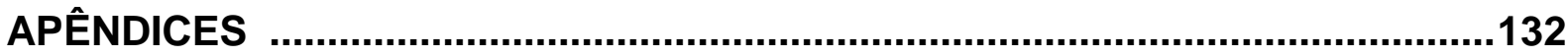

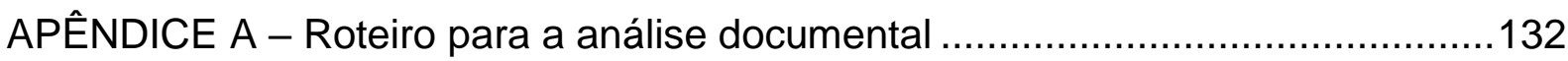

APÊNDICE B - Aprovação dos currículos subnacionais ......................................133

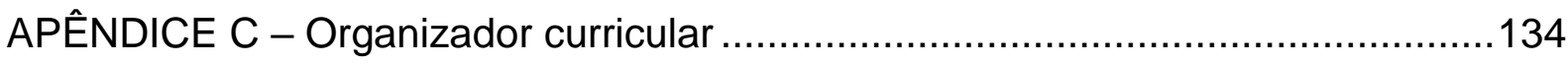

ANEXOS

ANEXO A - Declaração de participação na audiência pública do CNE ..................139

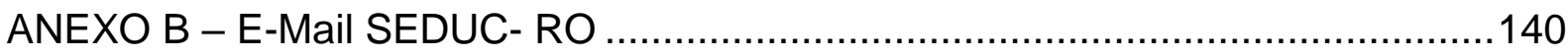

ANEXO C - E-Mail MEC sobre a aprovação dos currículos subnacionais .............142

ANEXO D - E-Mail MEC sobre o custo da BNCC aos cofres públicos ..................144 


\section{BREVE MEMORIAL}

As inquietações para esta pesquisa emergiram quando da minha atuação no Centro Interescolar de Línguas (CIL) 1 de Brasília, instituição da Secretaria de Estado de Educação do Distrito Federal (SEEDF), onde fui aluna, atuei como professora regente desde 2001 e estava exercendo a função docente na Sala de Recursos Generalista ${ }^{1}$ nos últimos cinco anos. Foi minha primeira experiência em Educação Especial na rede pública de ensino, mesmo tendo feito cursos e estágio nessa área em rede privada de ensino.

O CIL tornou-se referência no ensino público de inglês ${ }^{2}$ por oferecer educação linguística voltada para a interculturalidade e para diferentes formas de expressão nos eixos de comunicação oral e produção escrita. Foi idealizado e concretizado por iniciativa da professora Nilce do Val Galante ${ }^{3}$, na década de 1970.

A Sala de Recursos Generalista (SRG) do CIL 1 de Brasília, pioneira no atendimento educacional especializado aos Alunos com Necessidades Educacionais Especiais (ANEE) em língua estrangeira, foi vitalizada em 2001 a partir do projeto Ensino de língua estrangeira para alunos com deficiência auditiva, de autoria da professora Denise G. de Britto Damasco ${ }^{4}$, antes mesmo da universalização da Educação Inclusiva nas escolas da rede pública de ensino do Distrito Federal em 2003 (Lei no 3.218) (DISTRITO FEDERAL, 2003). Inovando, assim, em um projeto de Educação Inclusiva e de justiça social mais amplo com a criação da primeira turma de inglês para surdos.

A Educação Especial é um campo de lutas em que avanços e recuos são constantes. Em 2018, por exemplo, sem ampla discussão e por consulta pública online, o Ministério da Educação (MEC) propôs a retirada do termo "na Perspectiva da Educação Inclusiva" da denominada Política Nacional de Educação Especial na Perspectiva da Educação Inclusiva (PNEEPEI) ${ }^{5}$. Isso representa um retrocesso de mais de três décadas para a educação especial, pois legitimaria a volta da natureza

\footnotetext{
1 Atende estudantes com laudo médico: das deficiências física, visual, auditiva, intelectual, mental; de Transtorno Global do Desenvolvimento (TGD), atual Transtorno do Espectro Autista (TEA); e de Altas Habilidades e Superdotação (AH/S).

2 British Council (2019, p. 97)

3 Resolução no 40 de 14 de agosto de 1975, vinculada ao Departamento de Ensino de 2ำ Grau da Diretoria Geral de Pedagogia pela Fundação Educacional do Distrito Federal (FEDF).

4 Proposta Pedagógica do CIL 1 de Brasília (DISTRITO FEDERAL, 2002).

$5 \operatorname{LEPED}(2018$, p. 54).
} 
substitutiva à escola comum, obstaculizando o acesso e, consequentemente, a inclusão social e escolar desses estudantes. A união de esforços entre familiares, instituições educacionais, profissionais da educação especial logrou suspender tal contrassenso.

A criação do CIL 1 e a vitalização de sua Sala de Recursos são exemplos de ações inovadoras "de baixo para cima", bottom-up, que se materializaram por iniciativa de professoras de vanguarda, atentas às demandas sociais e educacionais da comunidade escolar, ao passo que a ação perpetrada pelo MEC, "de cima para baixo", top-down, demonstra o sobrestamento normativo governamental em questão de natureza estatal que a Educação deveria configurar.

Nos exemplos acima, as relações de poder, a conjuntura socioeconômica, a mobilização da sociedade civil e o engajamento dos múltiplos atores sociais e políticos, dotados de certa autonomia, recursos e estratégias determinaram o êxito das duas primeiras ações e o fracasso da empreitada do MEC.

Essas compreensões robusteceram-me a partir da minha atuação na SRG, pois este docente é um dos responsáveis pela inclusão na escola e por orientar estratégias didático-pedagógicas, de adaptações curriculares e arquitetônicas com vistas a afastar barreiras físicas e atitudinais. São requeridos, desse profissional, conhecimentos atualizados acerca das especificidades dos ANEE e das normatizações legais e infralegais, nacionais e supranacionais, a fim de que sejam garantidas condições de acesso, permanência e atendimento de qualidade.

De modo que ao estudar a BNCC, inquietei-me a respeito das dinâmicas propiciadoras dessa norma, do jogo político em que foi produzida, dos atores com seus interesses, das representações e dos sentidos em torno dessa política educacional e curricular tão complexa e ampla. Assim, propus pesquisar os textos e os contextos desta reforma educacional atual, uma vez que tenho observado os mo(vi)mentos - ações e conjunturas - centrais e locais "de cima para baixo" e "de baixo para cima" que ensejam mudanças e transformações sociais. 


\section{INTRODUÇÃO}

A previsão de um "núcleo comum, obrigatório em âmbito nacional, e uma parte diversificada" para a Educação Básica nacional começa a se firmar em 1971 (artigo 4으, Lei oㅜ 5.692/1971) (BRASIL, 1971) como resultado dos debates acadêmicos sobre educação na década de 1960 e se corporifica como Base Nacional Comum Curricular (BNCC), quase cinco décadas depois, ensejada pela redemocratização e pela Constituição Federal de 1988 (BRASIL, 1988).

A Constituição Cidadã, como é conhecida por ampliar os direitos sociais e os instrumentos de participação democrática, cooperativa e fiscalizatória, prevê, em seu artigo 210, a fixação de conteúdos mínimos para o ensino fundamental. Normas legais e infralegais essenciais foram editadas desde então, como: Guias Curriculares, na década de 1990; a Lei de Diretrizes e Bases/1996 (BRASIL, 1996); os Parâmetros Curriculares Nacionais (PCN); as Diretrizes Curriculares Nacionais (DCN); e os Planos Nacionais de Educação (PNE).

Nesse percurso histórico, houve progressos e retrocessos na agenda educacional nacional, marcados pela instituição do direito à educação de qualidade como dever do Estado, da democratização do acesso, do federalismo cooperativo, da gestão democrática, de fundos de manutenção e desenvolvimento da educação e de valorização do magistério.

No entanto, a desarticulação entre os agentes estatais, a descontinuidade de ações de financiamento e a fragmentação de programas impediram o equacionamento de questões de acesso, evasão, repetência, distorção idade-série, assim como a erradicação do analfabetismo. Argumentos utilizados pelo Estado para justificar a premência de uma base nacional comum curricular para a Educação Básica, obrigatória para todas as escolas públicas e privadas do País.

Saviani (2016b) e Frigotto (2018) asseveram que as bases já estavam dadas, eram democráticas ao preverem que as escolas definissem, em seu Projeto PolíticoPedagógico, os conteúdos e as concepções de currículo adotados. "Se a base comum já se encontra definida por meio das diretrizes curriculares nacionais, que são mantidas, qual o sentido desse empenho em torno da elaboração e aprovação de uma nova norma relativa à "base nacional comum curricular?" (SAVIANI, 2016b, p. 75).

Freitas (2015) alerta ao afirmar: 
Se é para se ter uma referência que dê parâmetros para as escolas (combinando conteúdos e níveis de complexidade de desempenho), tudo bem. Se é para responsabilizar escolas, impor uma cultura padrão sobre outras culturas, punir ou premiar professores, trocar diretores, pagar bônus, credenciar professores, orientar grandes conglomerados empresariais a produzir material didático, privatizar, engessar a formação de professores e outras ideias já testadas em outros lugares e que destruíram por lá o sistema público de educação, então a resposta é não (FREITAS, 2015, n.p.).

No bojo desse debate, os reformadores empresariais da educação ${ }^{6}$, organizados em torno do Movimento pela Base Nacional Comum ${ }^{7}$, têm empenhado esforços na legitimação desse documento nacional desde 2013. Contudo, somente com a edição da Portaria no 592/2015 (BRASIL, 2015b), recursos materiais e intelectuais começaram a ser mobilizados para a concretização da BNCC.

O processo de construção da base vem marcado por ações divergentes entre o Estado e os múltiplos atores sociais evocados e subsumidos, além de tensionado por crises políticas institucionais significativas, como o impeachment da presidenta Dilma Rousseff e os atos supervenientes perpetrados por seu sucessor, Michel Temer, como a reforma do ensino médio por meio da Medida Provisória 746/2016 convertida na Lei no 13.415/2017 (BRASIL, 2017a).

Todas as versões da Base, segundo o MEC, foram submetidas a consultas públicas pela internet e receberam mais de 12.000 .000 (doze milhões) de contribuições de cidadãos e instituições, além de pareceres de especialistas brasileiros e estrangeiros, entidades científicas e membros da comunidade acadêmica.

Afora as consultas públicas, o Conselho Nacional de Educação (CNE), órgão de Estado integrante do Ministério da Educação, organizou audiências públicas ${ }^{8}$ regionais para a legitimação da Base. No entanto, a configuração das audiências comprometeu, precisamente, a perspectiva democrática, na medida em que o CNE não contemplou as demandas críticas - inclusos os pedidos por mais tempo e

6 Termo cunhado por Diane Ravitch para designar o corporate reformers nos Estados Unidos e traduzido por Luiz Carlos de Freitas, que designa a aliança entre empresários, políticos, empresas educacionais, institutos e fundações privadas, mídia e pesquisadores que se alinham à lógica liberal, conservadora, centrista da reforma corporativa privatizante da educação pública (FREITAS, 2018a).

7 Fundação Lemann, Fundação Roberto Marinho, Instituto Ayrton Senna, Itaú BBA, Instituto Unibanco, Todos pela Educação, dentre outros. Cf. http://movimentopelabase.org.br/quem-somos/ Acesso em: 29 set. 2018.

8 Observação presencial da audiência pública realizada em Brasília/DF, no dia 14 set. 2018. (Anexo A), descrita no capítulo 3. 
espaço para o debate - das comunidades acadêmica, educacional e escolar presentes.

Desse modo, discutimos a Base enquanto instrumento de ação pública, caracterizado como "[...] um dispositivo simultaneamente técnico e social que organiza relações sociais específicas entre o poder público e seus destinatários em função de representações e de significações de que ele é portador." (LASCOUMES; LE GALÈS, 2012, p. 200). Este documento medeia as políticas educacionais e curriculares, e tornou-se um elemento sem correspondência cognitiva com as normas anteriormente instituídas quando a BNCC da Educação Infantil e do Ensino Fundamental (BNCC El/EF) foi homologada apartada da BNCC do Ensino Médio (BNCC EM), ferindo, desse modo, o princípio conceitual de Educação Básica da Lei de Diretrizes e Bases da Educação Nacional (LDBEN/1996). Para Cruz (2017, p. 77), "Os instrumentos seriam como mapas orientadores da ação, pilotos que editam as regras, exprimem escolhas, organizam mudanças pautadas em princípios compartilhados, tornam-se soluções naturais, levam à dependência".

A BNCC da Educação Infantil e do Ensino Fundamental (BNCC El/EF) foi homologada em dezembro de 2017 e a BNCC do Ensino Médio (BNCC EM) um ano mais tarde, em 2018. Constituem o "[...] conjunto orgânico e progressivo de aprendizagens essenciais que todos os alunos devem desenvolver ao longo das etapas e modalidades da Educação Básica, de modo que tenham assegurados seus direitos de aprendizagem e desenvolvimento" (BRASIL, 2016b, p. 5).

Em relação à fundamentação teórico-pedagógica da BNCC, esta norma se baseia no desenvolvimento de Competências, haja vista ser

[...] esse também o enfoque adotado nas avaliações internacionais da Organização para a Cooperação e Desenvolvimento Econômico (OCDE), que coordena o Programa Internacional de Avaliação de Alunos (Pisa, na sigla em inglês), e da Organização das Nações Unidas para a Educação, a Ciência e a Cultura (Unesco, na sigla em inglês), que instituiu o Laboratório Latino-Americano de Avaliação da Qualidade da Educação para a América Latina (LLECE, na sigla em espanhol) (BRASIL, 2016b, p. 11).

As escolhas teórico-epistemológicas para estruturar uma reforma educacional não são neutras, dizem-nos do modo como a realidade é compreendida, do ponto de vista adotado para determinados problemas e das intencionalidades expressas e latentes para a educação. Autores renomados do campo do currículo destacam 
pontos cruciais que precisam ser considerados antes de se desenvolver currículos nacionais baseados em Competências.

Esse enfoque no campo educacional é controverso, polêmico e se originou na educação profissionalizante com o objetivo de habilitar os alunos das classes menos favorecidas para o mercado de trabalho. Segundo Santomé (2011, p. 171), essa perspectiva é complexa, visto que "[...] não existe uma definição de consenso em relação ao termo "competências"; há diversos e opostos significados o que já aponta para o fato de que é um conceito ambíguo e, portanto, inconsistente no momento de se apresentar como eixo sustentador de uma Reforma".

Ao elegerem, textualmente, o enfoque em Competências e definirem os conteúdos mínimos como eixos estruturantes atrelados às avaliações externas, os especialistas converteram em referência os parâmetros internacionais ao que deve ser ensinado, aprendido e avaliado no Brasil. Para Sacristán et al. (2011, p. 21) a informação que os relatórios PISA proporcionam "[...] tem uma funcionalidade que delimita e limita seu poder de uso para conhecer e melhorar seu sistema educacional e suas práticas. Tratá-lo como se tivesse mais capacidade de informar do que tem não é correto do ponto de vista técnico, intelectual e moral."

Quanto à teoria curricular que embasa a BNCC, não há nenhuma adesão explícita na norma. Ao mesmo tempo que se foca em um currículo globalizado, propõe-se um currículo voltado para a "[...] realidade local, considerando a autonomia dos sistemas ou das redes de ensino e das instituições escolares, como também o contexto e as características dos alunos." (BRASIL, 2016b, p. 14). Essa contradição pode trazer equívocos e impasses quando da modelagem curricular dos currículos subnacionais ${ }^{9}$ à luz da Base.

Coube aos estados e ao Distrito Federal, por meio dos seus sistemas e redes públicas de ensino, com a aprovação dos seus respectivos Conselhos de Educação (CE), adequar suas propostas curriculares aos 60\% (sessenta por cento) dos conteúdos propedêuticos da BNCC e complementarem os 40\% (quarenta por cento) da parte diversificada com suas especificidades regionais e locais. Para isso, o MEC disponibilizou assistência técnica e financeira às Unidades da Federação (UF), por meio do Programa de Apoio à Implementação da Base Nacional Comum Curricular

9 Termo utilizado para denotar estados, municípios e DF, e conotar hierarquicamente inferior em relação à política verticalizada da BNCC. 
(ProBNCC), Artigo 1ํㅡ, Portaria n 331/2018 "[...] no processo de revisão ou elaboração e implementação de seus currículos alinhados à BNCC, em regime de colaboração entre estados, Distrito Federal e municípios" (BRASIL, 2018a).

Estudos anteriores ${ }^{10}$ revelaram um movimento progressivo curricular nacional desde a década de 1990 até 2014, período anterior à construção da BNCC, e revelaram marcas das orientações dos Parâmetros e Diretrizes Curriculares Nacionais nas propostas curriculares das UF, que serviram de modelo curricular a partir de 1997, além de identificarem que alguns estados brasileiros não dispunham ou não disponibilizaram seus documentos curriculares à época ${ }^{11}$.

Em 2018, Amapá (AP), Ceará (CE), Distrito Federal (DF), Espírito Santo (ES), Goiás (GO), Maranhão (MA), Mato Grosso (MT), Mato Grosso do Sul (MS), Minas Gerais (MG), Pará (PA), Paraíba (PB), Paraná (PR), Pernambuco (PE), Rio Grande do Norte (RN), Rio Grande do Sul (RS), Rondônia (RO) e Sergipe (SE) estavam com seus currículos da Educação Infantil (EI) e do Ensino Fundamental (EF) atualizados e aprovados pelos respectivos Conselhos de Educação diante a BNCC. Os demais estados concluíram essas fases em $2019^{12}$.

No entanto, o currículo do estado de Rondônia não compõe o corpus desta pesquisa por razões apresentadas em e-mail pela SEDUC-RO (Anexo B), de modo que as análises incidiram sobre os currículos para a Educação Infantil e o Ensino Fundamental $^{13}$ de 26 unidades da Federação, sendo 25 estados e o Distrito Federal $^{14}$.

Pressupomos que grande parte das unidades da Federação absorveram as prescrições da BNCC em seus documentos quanto aos fundamentos teóricopedagógicos, às concepções de educação e à forma de organização curricular.

Esta dissertação está aplicada ao grupo de pesquisa "Currículo e processo formativo" (FE/UnB) na qual empregamos os elementos da teoria crítica de currículo para as análises.

Os eixos: políticas públicas educacionais e curriculares; e teorias e concepções de educação e de currículo estruturam esta pesquisa que se justifica

10 Sampaio (2010) e CENPEC (2015).

11 Os currículos dos estados de RR, MA, PB, SE, RN e PI ficaram de fora do estudo de (SAMPAIO, 2010). Já os do CE, PA, RS e RR não foram analisados pelo (CENPEC, 2015).

12 E-mail do MEC (Anexo C).

13 Os currículos para o Ensino Médio não foram, ainda, aprovados pelos Conselhos de Educação.

14 Disponível em: http://basenacionalcomum.mec.gov.br/index.php?option=com_content\&view= article\&layout=edit\&id=207. Acessado em: 6 jan. 2020. Acessado em: 6 jan. 2020. 
por i) retratar o atual cenário curricular nacional, neste, que é o primeiro estudo stricto sensu da Universidade de Brasília e da Faculdade de Educação sobre a Base Nacional Comum Curricular ${ }^{15}$, ii) investigar o processo sociopolítico de elaboração e implementação da BNCC nas UF e iii) conhecer as opções teórico-epistemológicas assumidas e subsumidas nas propostas curriculares que sustentam o modelo de educação e sociedade idealizado.

Pautamo-nos em construtos teórico-metodológicos da pesquisa qualitativa e das estratégias de revisão bibliográfica e análise documental para a construção dos dados apoiada em Fetterman (1998), Flick (2009), Minayo et al. (2016), Ribas (2004), Triviños (1987) dentre outros. Procedemos à observação do fenômeno sob o influxo conceitual da Sociologia da Ação Pública de Lascoumes e Le Galès (2012), Muller e Surel (2002) e das concepções críticas de educação e de currículo, principalmente, em Borges (2014), Freitas (2002, 2018), Sacristán (2000, 2011) Saviani (2010, 2012, 2013), Santomé (2011), Silva F. (2018, 2020), Silva (2002). As análises dos dados ocorreram por meio da Análise de Conteúdo de Bardin (2009). Por meio dessas lentes, concretiza-se este estudo descritivo-comparativo e dialético dos (con)textos da BNCC El/EF e dos currículos das unidades da Federação.

Isso posto, propomos o seguinte problema central de pesquisa: De que forma as unidades da Federação atualizaram seus currículos à luz da BNCC?

O objetivo geral é compreender de que forma as unidades da Federação atualizaram seus currículos à luz da BNCC.

Os objetivos específicos são: a) discutir a premência de uma Base Nacional Comum Curricular; b) averiguar se as UF estão absorvendo a BNCC como prescrição ou como orientação; c) identificar os pressupostos teóricoepistemológicos que sustentam as propostas curriculares subnacionais; e d) estimar o grau de adesão dos currículos à BNCC.

Esses são conhecimentos relevantes que podem fornecer elementos para a avaliação da política da Base, a elaboração de novas políticas públicas em Educação, bem como viabilizar novos estudos e avanços teórico-práticos nos campos educacional, curricular e da formação dos profissionais da educação.

Constituem perguntas de pesquisa:

15 Busca realizada em 11 maio 2020. Disponível em: https://repositorio.unb.br/community-list. 
- É imprescindível uma Base Nacional Comum Curricular para a Educação brasileira?

- Quais são os fundamentos teóricos explícitos e implícitos que sustentam as escolhas pedagógicas e curriculares dos documentos?

- Qual é o grau de adesão dos currículos subnacionais à BNCC?

\subsection{Produto técnico da pesquisa}

O "produto é algo tangível, que se pode tocar, ver, ler etc." (CAPES, 2019, p. 16), por meio do qual os resultados da investigação e as contribuições da pesquisa se expressam. Nesse sentido, propomos um curso em nível de Pós-Graduação lato sensu intitulado "Base Nacional Comum Curricular e Organização do Trabalho Pedagógico" (BNCC e OTP) com carga horária de 450 horas para estudos teóricopráticos no campo educacional e curricular aos profissionais da educação das redes de ensino e instituições públicas e privadas, apresentado a seguir:

\section{Proposta de Pós-Graduação em Educação latu sensu}

\section{a) Título}

Base Nacional Comum Curricular e Organização do Trabalho Pedagógico (BNCC e OTP)

\section{b) Justificativa}

A reforma da Educação Básica induzida pela Base Nacional Comum Curricular (BNCC) impeliu o debate sobre questões curriculares e a organização do trabalho pedagógico da escola e da sala de aula nas redes de ensino e instituições públicas e privadas do país.

Faz-se necessário, nesse processo, realizar estudos teórico-práticos no campo educacional e curricular, visto que inúmeras agendas surgem desse movimento de alinhamento ao nacional e de autenticação local, tais como: autonomia e formação docente; gestão da educação; ensino a distância para a educação básica; avaliação, entre outros. 
Desse modo, propomos o Curso "BNCC e OTP", em nível de Pós-Graduação lato sensu, a fim de envolver a comunidade educacional e escolar nessas reflexões em prol de uma educação crítica, emancipadora e socialmente referenciada.

\section{c) Objetivos}

\section{Geral}

Discutir acerca das questões educacionais e curriculares em nível de pósgraduação lato sensu com os profissionais da educação básica.

\section{Específicos}

- Desenvolver a articulação entre teoria e prática para o processo de modelagem curricular à luz da BNCC.

- Instigar a valorização da localidade escolar e das ações de professores e alunos.

- Promover atividades práticas para a implementação participativa e democrática da política curricular nacional.

\section{d) Público-alvo}

Profissionais da educação básica das redes de ensino e de instituições públicas e privadas.

\section{e) Carga horária} $450 \mathrm{~h}$.

\section{f) Metodologia}

Os módulos serão estudados considerando a unidade teoria/prática em salas de aula física e virtual - modalidade híbrida - para aulas expositivas dialogadas, fóruns, painéis, pesquisas de campo etc.

\section{MATRIZ CURRICULAR}

São apresentadas, a seguir, as matrizes curriculares da proposta de PósGraduação em latu sensu: 
Quadro 1 - Proposta de matriz curricular de Pós-Graduação em latu sensu Módulo I - Metodologia da pesquisa em educação - 40h

$$
\text { MÓDULO I - METODOLOGIA DA PESQUISA EM EDUCAÇÃO - } 40 \text { h }
$$

Ementa:

- Pesquisa historiográfica aplicada ao campo educacional: fontes primárias

- Estado do conhecimento ou Estado da arte nas pesquisas em Educação.

- Estudos sobre as concepções epistemológicas acerca do conhecimento científico, partindo dos diferentes tipos de conhecimento.

- Estudo do Método Científico.

- Metodologias, técnicas e instrumentos para pesquisa educacional, em consonância com as normas vigentes da ABNT.

- O lugar do pluralismo epistemológico e metodológico nas pesquisas.

- Ética na pesquisa.

- Relação entre escrita científica e construção de um projeto curricular.

\section{Bibliografia:}

- GATTI, Bernadete Angelina. A construção da pesquisa em educação no Brasil. Brasília: Líber Livro, 2010.

- GIL, Antônio Carlos. Métodos e técnicas de pesquisa social, 5. ed. São Paulo: Atlas, 1999.

- LUDKE, Menga. Pesquisa em educação: abordagens qualitativas. São Paulo: EPU, 1986.

- MADEIROS, João Bosco. Redação Científica: a prática de fichamentos, resumos, resenhas, 6. ed. São Paulo: Atlas, 2004.

- MAINARDES, Jefferson. A pesquisa no campo da política educacional: perspectivas teórico-epistemológicas e o lugar do pluralismo. Revista Brasileira de Educação, v. 23, e230034, 2018.

- MINAYO, Maria C.S. (org.). Pesquisa social: teoria, método e criatividade. 6. ed. Petrópolis: Vozes, 1996.

- SILVA, Francisco Thiago; BORGES, Lívia Freitas F. Currículo e Ensino de História: um estado do conhecimento no Brasil. Educação \& Realidade, v. 43, n4, p. 1693-1723, out./dez. 2018.

- SILVA, F. T.; VILLAR, J. L.; BORGES, L. F. F. História e historiografia da educação brasileira: teorias e metodologias de pesquisa. Curitiba: Appris, 2020.

- TRIVIÑOS, Augusto N.S. Introdução à pesquisa em ciências sociais: a pesquisa qualitativa em educação. São Paulo: Atlas, 1995. 
Quadro 2 - Proposta de matriz curricular de Pós-Graduação em latu sensu -

Módulo II - Teorias de educação e concepções pedagógicas - $45 \mathrm{~h}$

MÓDULO II - TEORIAS DE EDUCAÇÃO E CONCEPÇÕES PEDAGÓGICAS $45 \mathrm{~h}$

EMENTA:

- Origem da educação, da escola e da profissão docente (mundo e Brasil).

- As teorias de educação: Não-criticas, Crítico-Reprodutivistas e Críticas

- Pedagogia Histórico-Crítica

- Pedagogia Crítico-social dos conteúdos.

- Psicologia Histórico-Cultural

- Tendências "Neo": Neoescolanovismo, Neoconstrutivismo, Neotecnicismo.

- Pedagogia das Competências / Aprender a Aprender.

Bibliografia:

- DELORS, J. Relatório para a UNESCO da Comissão Internacional sobre Educação para o século XXI. São Paulo, p. 288. 1999. (370.905).

- DUARTE, N. As pedagogias do "aprender a aprender" e algumas ilusões da assim chamada sociedade do conhecimento. Revista Brasileira de Educação, Rio de Janeiro, RJ, p. 35-40, set./out./nov./dez. 2001. ISSN 18.

- MALANCHEN, Julia. Cultura, Conhecimento e Currículo: contribuições da pedagogia histórico-crítica. Campinas, SP: Autores Associados, 2016.

- NEWTON, Duarte. Os conteúdos escolares e a ressurreição dos mortos: contribuição à teoria histórico-crítica do currículo. Campinas, SP: Autores Associados, 2016.

- SANTOMÉ, Jurjo Torres. Evitando o debate sobre a cultura no sistema educacional: como ser competente sem conhecimento. In: SACRISTÁN, José Gimeno Et. Al. Educar por Competências: o que há de novo? Porto Alegre, RS: Artmed, 2011.

- SAVIANI, D. Escola e democracia. 42. ed. Campinas: Autores Aassociados, 2012. 93 p.

- SAVIANI, Dermeval. História das ideias pedagógicas no Brasil. 3. ed. ver. Campinas, SP: Autores Associados, 2010.

- SAVIANI, Dermeval. Pedagogia histórico-crítica: primeiras aproximações. 11. Ed. Campinas: Autores Associados, 2012.

- VIGOTSKY, Lev Semionovitch. A defectologia e o estudo do desenvolvimento e da educação da criança anormal. Educação e Pesquisa, São Paulo, v. 37, n. 4, p. 861-870, 2011.

- VIGOTSKY, Lev Semionovitch. A construção do pensamento e da linguagem. São Paulo: Martins Fontes, 2001. 
Quadro 3 - Proposta de matriz curricular de Pós-Graduação em latu sensu Módulo III - Teorias de concepções curriculares - 45h

\section{MÓDULO III - TEORIAS E CONCEPÇÕES CURRÍCULARES - 45 h}

\section{Ementa:}

- Origem do campo, Múltiplos conceitos de currículo.

- As teorias de currículo: Tradicional, Crítica e Pós-Crítica

- O Movimento de Reconceptualização.

- Pós-Modernismo.

- Multiculturalismo.

- Escolas teóricas e ligação com o campo curricular: Positivismo, Marxismo, Nova Sociologia da Educação - NSE, Pós-Estruturalismo.

- Processos de desenvolvimento curricular: do currículo prescrito ao currículo avaliado.

- Currículo integrado e interdisciplinaridade

- Ideologia e globalização.

- Currículo e formação de profissionais da Educação.

\section{Bibliografia:}

- APPLE, Michael. Ideologia e Currículo. Porto Alegre: Artmed, 2006.

- BORGES, L. F. F. Eixo estruturante e transversalidade: elementos orientadores dos currículos da formação de profissionais da educação. EdUECE, v. 4, p. 1181-1199, 2014.

- MOREIRA, Antonio Flavio Barbosa; CANDAU, Vera Maria. Indagações sobre currículo: currículo, conhecimento e cultura. Brasília: Ministério da Educação, Secretaria de Educação Básica, 2008.

- MOREIRA, Antônio Flávio Barbosa; CANDAU, Vera Maria (Orgs.).

Multiculturalismo: diferenças culturais e práticas pedagógicas. Petrópolis: Vozes, 2010.

- MOREIRA, Antonio Flavio Barbosa. Currículos e Programas no Brasil. Campinas: Papirus, 2012.

- SACRISTÁN, J. O currículo: uma reflexão sobre a prática. 3. ed. Porto Alegre: Artes Médicas, 2000.

- SILVA, Francisco Thiago. Currículo integrado, eixo estruturante e interdisciplinaridade: uma proposta para a formação inicial de pedagogos. Brasília: Editora Kiron, 2020.

- SILVA, Tomaz Tadeu da. Documentos de identidade: uma introdução às teorias do currículo. Belo Horizonte: Autêntica, 2011.

- YOUNG, Michael F. D. Conhecimento e Currículo na Sociologia da Educação. In: YOUNG, Michael F. D. Conhecimento e Currículo: Do socioconstrutivismo ao realismo social na sociologia da educação. Porto, PT: Porto Editora, 2010. 
Quadro 4 - Proposta de matriz curricular de Pós-Graduação em latu sensu Módulo IV - BNCC: fundamentos e processos $-35 \mathrm{~h}$

MÓDULO IV - BNCC: fundamentos e processos $-35 \mathrm{~h}$

\section{Ementa:}

- Princípios.

- Marcos legais.

- História da construção.

- Metodologia de elaboração: tramitação, aprovação e homologação.

- Reformas educacionais.

- Resolução do Conselho Nacional de Educação.

- PróBNCC.

- Estrutura da BNCC.

\section{Bibliografia:}

- BRANCO, E. P. et al. A Implantação da Base Nacional Comum Curricular no Contexto das Políticas Neoliberais. 1. ed. Curitiba: Appris, 2018. 135 p.

- BRASIL. Base Nacional Comum Curricular: Educação Infantil e Ensino Fundamental. Diário Oficial da União: seção: 1, Brasília, DF, p. 42, 22 dez. 2016.

- BRASIL. Base Nacional Comum Curricular: Ensino Médio. Diário Oficial da União: República Federativa do Brasil: seção: 1, Brasília, DF, ano 155, p. 146, 21 dez. 2017.

- BRASIL. Constituição da República Federativa do Brasil de 1988. Diário Oficial da União: República Federativa do Brasil: seção 1, p. 1, 5 out. 1988.

- BRASIL. Lei no 13.415, de $\mathbf{1 6}$ de fevereiro de 2017. Altera as Leis nos 9.394, de 20 de dezembro de 1996, que estabelece as diretrizes e bases da educação nacional. Diário Oficial da União: seção 1, Brasília, DF, p. 1, 17 fev. 2017.

- BRASIL. Ministério da Educação; Conselho Nacional de Educação. Audiências públicas sobre a Base Nacional Comum Curricular. Caderno Técnico. Brasília, DF, 2018.

- FREITAS, L. C. A reforma empresarial da educação: nova direita, velhas ideias. 1. ed. São Paulo: Expressão Popular, 2018. 160 p.

- MAINARDES, J.; FERREIRA, M. D. S.; TELLO, C. Análise de políticas: fundamentos e principais debates teórico-metodológicos. In: MAINARDES (Orgs), J.; MAINARDES, J. Políticas educacionais: questões e dilemas. 1. ed. São Paulo: Cortez, 2011. Cap. 6, p. 286.

- SILVA, E. F.; PAULA, A. V. BNCC DO ENSINO MÉDIO E TRABALHO PEDAGÓGICO: propostas da audiência pública de Brasília. Currículo sem Fronteiras, v. 19, p. 992-1010, set.-dez. 2019. ISSN 1645-1384. 
Quadro 5 - Proposta de matriz curricular de Pós-Graduação em latu sensu -

Módulo V - BNCC da Educação Infantil - 35h

\section{MÓDULO V - BNCC da Educação Infantil - 35h}

\section{Ementa:}

- O conceito de infância e criança no contexto da Educação Básica.

- A educação infantil na BNCC.

- Campos de experiências.

- Objetivos de aprendizagem e desenvolvimento.

- A transição da Educação Infantil para o Ensino Fundamental.

\section{Bibliografia:}

- BRASIL. Base Nacional Comum Curricular: Educação Infantil e Ensino Fundamental. Diário Oficial da União: seção: 1, Brasília, DF, p. 42, 22 dez. 2016

- BARBOSA, I. G.; SILVEIRA, T. A. T. M.; SOARES, M. A. A BNCC da Educação Infantil e suas contradições: regulação versus autonomia. Retratos da Escola / Escola de Formação da Confederação Nacional dos Trabalhadores em Educação (Esforce), Brasília, v. 13, n.25, p. 77-90, jan.-mai. 2019. Disponivel em: $<\mathrm{http} / \mathrm{www}$.esforce.org.br>.

- COLE, M.; COLE, S. R. O desenvolvimento da criança e do adolescente. Porto Alegre, RS: Artmed, 2003.

- LURIA, A. R. Desenvolvimento cognitivo. SP: Ícone, 1990.

Fonte: Elaborado pela autora (2019).

Quadro 6 - Proposta de matriz curricular de Pós-Graduação em latu sensu Módulo VI - BNCC do Ensino Fundamental - 35h

\section{MÓDULO VI - BNCC do Ensino Fundamental - 35h}

\section{Ementa:}

- O Ensino Fundamental no contexto da Educação Básica - anos iniciais e anos finais.

- O Ensino Fundamental no contexto da BNCC - anos iniciais e anos finais.

- As áreas do conhecimento.

- Campos de atuação.

- Objetos de conhecimento.

- Competências / Habilidades.

- Transição entre os anos iniciais e os anos finais.

- Transição entre os anos finais e o Ensino Médio.

\section{Bibliografia:}

- BRASIL. Base Nacional Comum Curricular: Educação Infantil e Ensino Fundamental. Diário Oficial da União: seção: 1, Brasília, DF, p. 42, 22 dez. 2016

- VEIGA, I. P. A. et al. Ensino Fundamental: da LDB à BNCC. 1. ed. Campinas, SP: Papirus, 2018. 272 p.

Fonte: Elaborado pela autora (2019). 
Quadro 7 - Proposta de matriz curricular de Pós-Graduação em latu sensu Módulo VII - BNCC do Ensino Médio - 45h

MÓDULO VII - BNCC do Ensino Médio - 45h

Ementa:

- O Ensino Médio no contexto da Educação Básica.

- O Ensino Médio no contexto da BNCC.

- $\quad$ Áreas do conhecimento.

- Itinerários Formativos.

- Eixos estruturantes.

Bibliografia:

- BORGES, L. F. F.; SILVA, F. T. Currículo do ensino médio: um recorte da atual rede pública de ensino do Distrito Federal. In: WELLER, W.; GAUCHE, R. (Orgs). Ensino Médio em debate: currículo, avaliação e formação integral. Brasília: Universidade de Brasília, 2017. Cap. 2, p. 284.

- BRASIL. Base Nacional Comum Curricular: Ensino Médio. Diário Oficial da União: República Federativa do Brasil: seção: 1, Brasília, DF, ano 155, p. 146, 21 dez. 2017.

- BRASIL. Ministério da Educação; Conselho Nacional de Educação. Diretrizes Curriculares Nacionais para o Ensino Médio. Atualiza as Diretrizes Curriculares Nacionais para o Ensino Médio. Conselho Nacional de Educação/Câmara de Educação Básica n.3/2018. Diário Oficial da União: República Federativa do Brasil: edição: 224, seção: 1, Brasília, DF, p. 21, 22 nov. 2018.

- LOPES, A. C. Itinerários formativos na BNCC do Ensino Médio: identificações docentes e projetos de vida juvenis. Retratos da Escola / Escola de Formação da Confederação Nacional dos Trabalhadores em Educação (Esforce), Brasília, v. 13, p. 59-76, jan.-mai. 2019. Disponivel em: $<$ http//www.esforce.org.br>.

- SÜSSEKIND, M. L. A BNCC e o "novo" Ensino Médio: reformas arrogantes, indolentes e malévolas. Retratos da Escola / Escola de Formação da Confederação Nacional dos Trabalhadores em Educação (Esforce), Brasília, v. 13, n.25, p. 91-108, jan.-mai. 2019. Disponivel em: $<$ http//www.esforce.org.br>. 
Quadro 8 - Proposta de matriz curricular de Pós-Graduação em latu sensu Módulo VIII - Organização do trabalho pedagógico - 35h

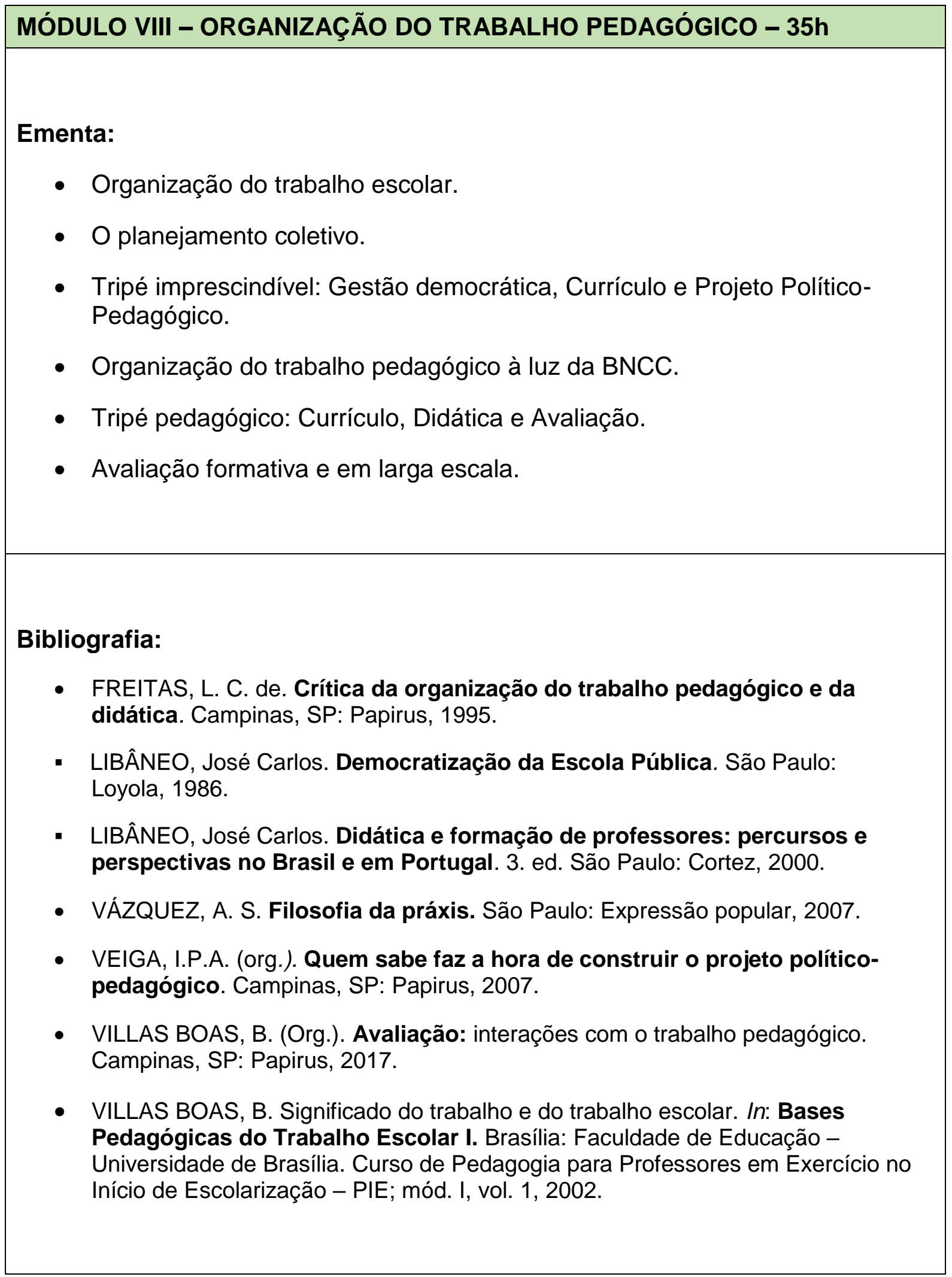

Fonte: Elaborado pela autora (2019). 
Quadro 9 - Proposta de matriz curricular de Pós-Graduação em latu sensu Módulo IX - Currículo integrado e escola de tempo integral - 35h

MÓDULO IX - CURRÍCULO INTEGRADO E ESCOLA DE TEMPO INTEGRAL $35 \mathrm{~h}$

Ementa:

- Currículo Coleção X Currículo Integrado (aproximações e diferenças).

- Eixos, temas, unidades: reflexões curriculares.

- Modelos de Integração curricular:

$>$ Multidisciplinaridade.

$>$ Pluridisciplinariedade.

$>$ Interdisciplinariedade.

> Transdisciplinaridade.

- Atividades práticas de integração: unidades didáticas e sequência didática.

- A escola de turno e a escola de tempo integral.

- Série, ciclo e semestralidade.

Bibliografia:

- ALVARENGA, Georfravia Montoza. Avaliar: um compromisso com o ensino e a

- BERNSTEIN, B. Clases, códigos y control: hacia una teoría de las transmisiones educativas. Madri: Akal, 1977.

- COELHO, Lígua Martha; CAVALIERE, Ana Maria. (Org). Educação Brasileira e(m) tempo integral. Petrópolis: Vozes, 2002.

- CHAVES, Miriam Waidenfild. Educação Integral: uma proposta de inovação pedagógica na administração escolar de Anísio Teixeira no Rio de Janeiro dos anos 30. In: COELHO, Lígia Martha; CAVALIERE, Ana Maria. (Org.). Educação brasileira $\mathrm{e}(\mathrm{m})$ tempo integral. Petrópolis: Vozes, 2002.

- LUCKESI, Cipriano Carlos. Avaliação da Aprendizagem Escolar. São Paulo: Cortez, 2013.

- VILLAS BOA SANTOMÉ, Jurjo Torres. Globalização e interdisciplinaridade: 0 currículo integrado. Porto Alegre: Artes Médicas, 1998.

- S, B.M.F. Portfólio, avaliação e trabalho pedagógico. 2004 (no prelo). São Paulo: Cortez, 1995.

Fonte: Elaborado pela autora (2019). 
Quadro 10 - Proposta de matriz curricular de Pós-Graduação em latu sensu Módulo X - O Currículo em movimento do Distrito Federal - 30h

MÓDULO X - O CURRÍCULO EM MOVIMENTO DO DISTRITO FEDERAL - 30h

Ementa:

- História da elaboração.

- Concepções teórico-pedagógicas.

- Organizador curricular.

- Grau de adesão à BNCC.

Bibliografia:

- DISTRITO FEDERAL. Secretaria de Educação. Currículo em Movimento do Distrito Federal: ensino fundamental anos iniciais-anos finais. Brasília, DF. 2018.

- DISTRITO FEDERAL. Secretaria de Estado de Educação do Distrito Federal. (SEEDF). Currículo em Movimento da Educação Básica: Pressupostos Teóricos. Brasília, 2014.

Fonte: Elaborado pela autora (2019).

Quadro 11 - Proposta de matriz curricular de Pós-Graduação em latu sensu Módulo XI - Profissionalidade, docência e formação curricular - 35h

\section{MÓDULO XI - PROFISSIONALIDADE, DOCÊNCIA E FORMAÇÃO} CURRICULAR - 35h

\section{Ementa:}

- Profissionalização e desprofissionalização.

- Desenvolvimento profissional docente.

- As funções de um curriculista.

- BNC-Formação - Base Nacional Comum para a Formação Inicial de Professores da Educação Básica.

\section{Bibliografia:}

- AGUIAR, M. A. D. S.; DOURADO, L. F. BNCC e formação de professores: concepções, tensões, atores e estratégias. Retratos da Escola / Escola de Formação da Confederação Nacional dos Trabalhadores em Educação (Esforce), Brasília, v. 13, n.25, p. 33-38, jan.-mai. 2019. Disponivel em: $<h t t p / / w w w . e s f o r c e . o r g . b r>$.

- ALBINO, Â. C. A.; SILVA, A. F. D. BNCC e BNC da formação de professores: repensando a formação por competências. Retratos da Escola / Escola de Formação da Confederação Nacional dos Trabalhadores em Educação (Esforce), Brasília, v. 13, n.25, p. 137-154, jan.-mai. 2019. Disponivel em: $<$ http//www.esforce.org.br>.

- BRASIL. Ministério da Educação. Conselho Nacional de Educação. Resolução CNE/CP no 2 de 20 de dezembro de 2019. Define as Diretrizes Curriculares Nacionais para a Formação Inicial de Professores para a Educação Básica e institui a Base Nacional Comum para a Formação Inicial de Professores da Educação Básica (BNC-Formação). Diário Oficial da União: República Federativa do Brasil: seção:1, Brasília, DF, 23 dez. 2019. 
Bibliografia:

- FARIAS, I. M. S. D. O discurso curricular da proposta para BNC da formação de professores da educação básica. Retratos da Escola / Escola de formação da Confederação Nacional dos Trabalhadores em Educação (Esforce), Brasília, v. 13, n.25, p. 155-168, jan.-mai. 2019. Disponivel em: $<$ http//www.esforce.org.br>.

- GIROUX, H. Os professores como Intelectuais Rumo a uma Pedagogia Crítica da Aprendizagem. Porto Alegre: Artes Médicas, 1997.

- LIBÂNEO, José Carlos. Pedagogia e pedagogos, para quê?. 12 ed. São Paulo: Cortez, 2010.

- SILVA, Kátia Augusta Curado Pinheiro Cordeiro da. Professores com formação stricto sensu e o desenvolvimento da pesquisa na educação básica da rede pública de Goiânia: realidade, entraves e possibilidades. 2008. 292 f. Tese de doutorado (Programa de Pós- Graduação em Educação) Faculdade de Educação, Universidade Federal de Goiás, Goiânia, 2008.

- VEIGA, I. P. A.; SILVA, E. F. (Orgs.). A escola mudou. Que mude a formação de professores! Campinas, São Paulo: Papirus, 2010.

Fonte: Elaborado pela autora (2019).

Quadro 12 - Proposta de matriz curricular de Pós-Graduação em latu sensu Módulo XII - Oficina prática de construção curricular - 35h

\section{MÓDULO XII - OFICINA PRÁTICA DE CONSTRUÇÃO CURRICULAR - 35h}

\section{Ementa:}

- Pressupostos teórico-metodológicos para construção de um currículo.

- Utilização de um roteiro orientador em grupos com orientação individual.

- Trabalho a ser realizado em conjunto e por etapas.

- Objetivo: apropriar-se do conhecimento e aplicá-lo diretamente em nossa realidade, com vistas ao TCC.

- Espera-se que o resultado desta disciplina seja a base para a construção do trabalho final de curso.

\section{Bibliografia:}

- AREOSA, Silvia Virginha Coutinho. Psicologia da Criança e Desenvolvimento Humano. EDUNISC,2005.

- FERNANDES, C. M. B.; FERNANDES, S. R. de S. As questões da prática pedagógica como componente curricular nas licenciaturas. $28^{\underline{a}}$ Reunião Anual da Anped (Associação Nacional de Pós-Graduação e Pesquisa em Educação), Caxambu (MG), 2005.

- MOREIRA, A. F. B. (Org.). Currículo na contemporaneidade: incertezas e desafios. 3. ed. São Paulo: Cortez, 2008

- MOREIRA, A. F. B. (Org.). Currículo: Questões Atuais- Campinas, SP: Papirus, 1997. (Coleção Magistério: Formação e Trabalho Pedagógico).

- SACRISTÁN, J. O currículo: uma reflexão sobre a prática. 3. ed. Porto Alegre: Artes Médicas, 2000. 


\section{AVALIAÇÃO}

O processo avaliativo contempla $75 \%$ de frequência, participação nos fóruns e nas atividades em grupo, e o trabalho final de curso.

Desse modo, tencionamos contribuir com a formação dos profissionais que acompanham e executam essa política pública, e com os debates educacional e curricular avivados pela BNCC.

\subsection{Quadro de coerência da pesquisa}

O Quadro 13 sintetiza a pesquisa em um quadro de coerência:

\section{Quadro 13 - Quadro de coerência da pesquisa}

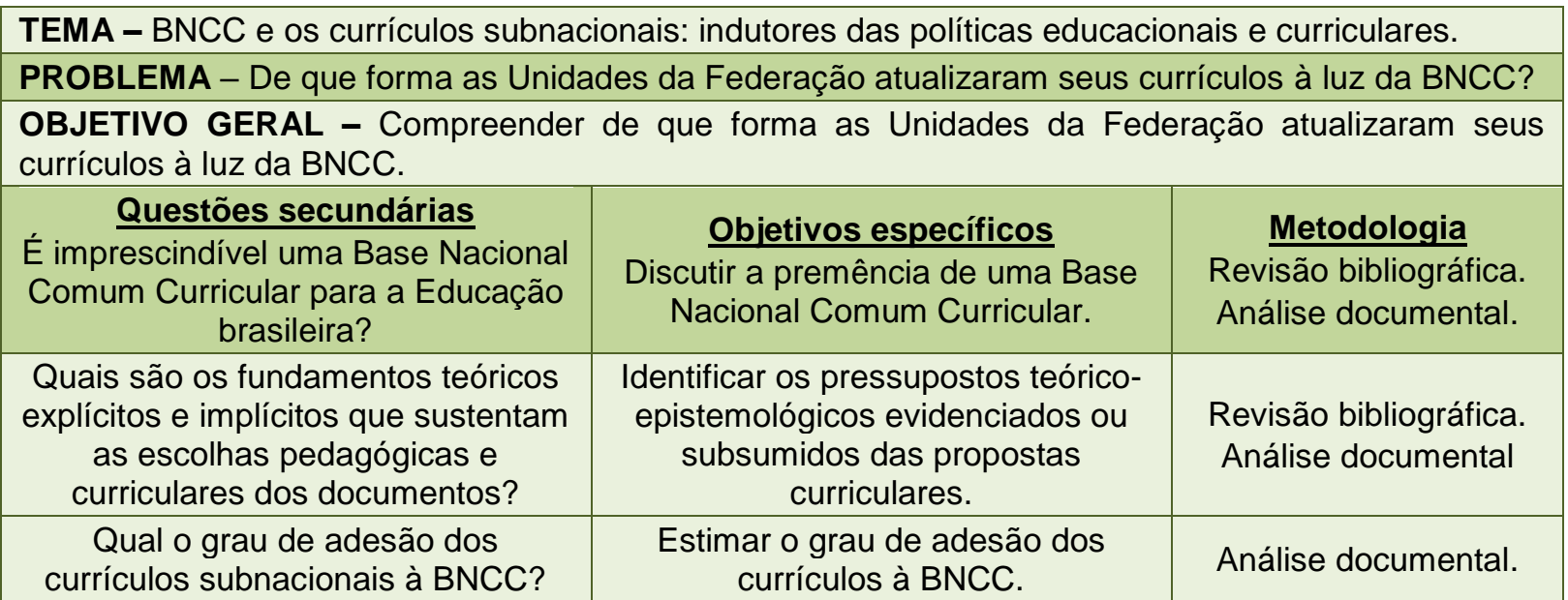

Produto técnico da pesquisa - Projeto de Pós-Graduação lato sensu intitulado "BNCC e OTP"

Fonte: Elaborado pela autora (2019).

Organizamos esta dissertação em cinco capítulos compostos por seções e subseções:

No capítulo 1, apresentamos a introdução do contexto para o tema, as referências teóricas do estudo, bem como a justificativa, os objetivos geral e específicos, a relevância e as perguntas de pesquisa. Por fim, apresentamos o produto técnico da pesquisa.

No capítulo 2, expomos a metodologia de construção, sistematização e análise dos dados da pesquisa, além do estado do conhecimento, na qualidade de 
técnica profícua em pesquisas educacionais, composto por produções acadêmicas que corroboram nosso objeto de estudo.

No capítulo 3, discutimos a complexidade política e a multiatorialidade da BNCC na perspectiva da Sociologia da Ação Pública e da permeabilidade estatal; abordamos a observação presencial da audiência pública organizada pelo CNE, arena de poder e de construção de sentidos. Ao final, tecemos as primeiras considerações.

No capítulo 4, tratamos das concepções de educação e de currículo, e das principais tendências pedagógicas e curriculares evidenciadas ou subsumidas nos currículos das unidades da Federação.

No capítulo 5, intitulado "Os currículos subnacionais à luz da BNCC: o que os dados revelam" trazemos as análises dispostas em aspectos gerais, organizador curricular, adesão à BNCC e as considerações finais.

No capítulo 6, tecemos as considerações finais. 


\section{ITINERÁRIOS METODOLÓGICOS}

Pesquisas na área de Educação são mais bem compreendidas e analisadas por um olhar qualitativo, uma vez que o dinamismo e a complexidade das relações sociais entre o objeto de estudo, os sujeitos imbricados e o pesquisador não são facilmente quantificáveis. Na medida em que esta pesquisa considera os contextos social, político e econômico, bem como as dinâmicas socioestatais que ensejaram a reforma da educação básica brasileira por meio da reforma curricular, o método qualitativo constitui a melhor opção.

As pesquisas qualitativas "[...] têm em comum o fato de buscarem esmiuçar a forma como as pessoas constroem o mundo à sua volta, o que estão fazendo ou o que está lhes acontecendo em termos que tenham sentido e que ofereçam uma visão rica" (FLICK, 2009, p. 12). Esta é entendida por Fetterman (1998, p. 19) como uma "visão macro e geral que cria uma espécie de fotografia do contexto geral", influenciada por aspectos históricos, políticos, econômicos e sociais, nos quais o objeto, os sujeitos e o pesquisador estão inseridos.

Em relação aos modos de raciocínio que o enfoque qualitativo pode assumir, Ribas (2004) discorre acerca do: indutivo, dedutivo, hipotético-dedutivo e dialético. Esta pesquisa se afilia ao dialético, pois essa modalidade peculiar do pensamento considera o processo histórico de mudanças e conflitos sociais que supera os modelos explicativos, construídos de análises visíveis de um objeto para dar conta das hipóteses do pesquisador em uma relação de causa/efeito.

Conforme Marx (1982), é o conhecimento do objeto, de sua estrutura e dinâmica, tal como ele é em si mesmo que permite ao pesquisador reproduzir em seu pensamento (reprodução ideal) a estrutura e a dinâmica (essência) do objeto que pesquisa. "E esta reprodução (que constitui propriamente o conhecimento teórico) será tanto mais correta e verdadeira quanto mais fiel o sujeito for ao objeto" (NETTO, 2011, p. 20).

Por isso, dialético, dado que não tem como romper a processualidade do vir a ser do homem, que ao se objetivar faz com que ele nunca seja o mesmo e, ao mesmo tempo, põe em movimento nexos causais da realidade que não existiriam sem a sua objetivação, "é o real e suas possibilidades" (HUNGARO, 2014, p. 26).

O estudo do movimento para explicar a realidade, em qualquer âmbito já era questão relevante para o pensamento clássico. Originou a teoria aristotélica das 
quatro causas - material, formal, motriz ou eficiente e final -, que tentou explicar de modo objetivo as mudanças naturais e humanas para lidar com a realidade em constante movimento. Modernamente, sob o influxo de Galileu, Bacon, Descartes e outros, as quatro causas foram reduzidas a duas: a eficiente e a final, passando-se "a dar à palavra 'causa' o sentido que hoje lhe damos, isto é, de operação ou ação" (CHAUI, 1985, p. 11).

Nesse continuum, teoria e prática se imbricam nos processos de construção do conhecimento e de apreensão da realidade. Saviani (2013b) pondera que:

[...] se a prática é o critério de verdade da teoria, eu formulo em nome da teoria determinados conceitos, determinadas hipóteses, mas isso precisa ser posto em prática para provar a sua validade e para saber-se em que grau ela de fato responde às necessidades em razão das quais foi proposta (SAVIANI, 2013b, p. 92).

Nessa dialética, em que as hipóteses são testadas em condições distintas ou até precárias, o que inviabiliza ou enseja o avanço da teoria, compreendemos o mo(vi)mento entre o Estado e os vários agentes sociais em torno da política pública curricular da BNCC como volátil, orgânico, mas nem por isso isento de comparação e categorização.

Triviños (1987) discorre sobre os tipos de estudos exploratórios, descritivos e experimentais. Nesta pesquisa, utilizamos o modo descritivo por permitir focar e descrever de modo mais "apurado" os fatos e os fenômenos atinentes à área educacional. O autor ressalta que "[...] os estudos descritivos não ficam simplesmente na coleta, ordenação, classificação dos dados. Podem estabelecer 'relações entre variáveis'" (TRIVIÑOS, 1987, p. 109), objetivo nosso.

Neste estudo descritivo, empregamos a modalidade de estudo bibliográfico e documental, que possibilita reunir uma grande quantidade de informação advinda de estudos anteriores, normas, leis, quadros de ação. Minayo et al. (2016, p. 57, grifo dos autores) ressaltam que a "pesquisa social trabalha com gente e com suas realizações, compreendendo as pessoas ou grupos como atores sociais em relação e em perspectivas" e que os documentos constituem os produtos dessas ações.

O Corpus documental desta pesquisa é composto pela versão final da BNCC El/EF (BRASIL, 2016b) e pela versão atualizada dos currículos para a educação 
infantil e o ensino fundamental de 25 estados e do Distrito Federal ${ }^{16}$. A totalidade dos estados e o Distrito Federal tiveram seus documentos curriculares aprovados, homologados e disponibilizados, em formato digital, nos sites das respectivas secretarias de educação, de onde os capturamos.

Essa realidade curricular inédita brasileira nos possibilitou analisar todos os currículos por meio dos eixos: políticas públicas educacionais e curriculares; e teorias e concepções de educação, organizados no roteiro analítico (Apêndice A).

\subsection{Procedimento da análise dos dados}

A sistematização dos dados e o procedimento de sua análise são processos mais complexos para Minayo et al. (2016), pois devem estar articulados em todas as etapas do trabalho, com a perspectiva teórico-metodológica adotada. O labor analítico do pesquisador, segundo os autores, permitirá o encaminhamento da pesquisa em direção à confiabilidade e à validade.

Para isso, adotaremos as técnicas de Análise de Conteúdo de Bardin (2009), que considera a prática e as significações (conteúdo) da língua realizada para além das palavras e da fala. Esse campo correlaciona-se com a sociolinguística, a semântica e a lexicologia na medida em que essas áreas deixam "[...] a esfera dessocializada da linguística e tenta descrever correspondências entre características <<linguajeiras>> e grupos sociais" (BARDIN, 2009, p. 46).

A análise de conteúdo complementa os procedimentos técnicos de classificação-indexação da análise documental, pois trabalha com a expressão do conteúdo, com a comunicação, e objetiva evidenciar indicadores para a descrição analítica de uma realidade para além da mensagem. Por meio dessa técnica, "podemos encontrar respostas para as questões formuladas" e o pesquisador vai "além das aparências do que está sendo comunicado" (MINAYO et al., 2016, p. 74).

Para isso, o pesquisador deve passar pelas fases definidas por Bardin (2009, p. 121), quais sejam: i) pré-análise; ii) exploração do material; e iii) tratamento dos resultados obtidos e interpretação. $\mathrm{Na}$ fase de pré-análise, escolhemos os documentos curriculares nacional e subnacionais, formulamos os objetivos e

16 O currículo do estado de Rondônia não compõe o corpus da pesquisa pelas razões apresentadas pela SEDUC-RO (Anexo B). 
elaboramos os descritores (Apêndice A) para a interpretação. No estágio de exploração do material, utilizamos a codificação, decomposição, enumeração em função da "sistemática das decisões tomadas" (BARDIN, 2009, p. 127). E, para o tratamento dos resultados obtidos e interpretação, procedemos, a uma "operação de classificação de elementos constitutivos de um conjunto por diferenciação e, em seguida, por reagrupamento segundo o gênero (analogia), com os critérios previamente definidos" (BARDIN, 2009, p. 128).

Em um esforço de referenciação, procedemos à busca por conceitos, expressões e referenciais bibliográficos que nos auxiliassem a identificar as opções teórico-pedagógicas dos currículos das UF e classificamo-las em: <<HÍBRIDA〉>, característica de uma teorização combinada em que se busca "[...] articular teorias ou conceitos oriundos de diferentes teorias, com o objetivo de compor um quadro teórico consistente" (MAINARDES, 2018); <<ECLÉTICA > que traz a noção de teorização adicionada que "[...] significa a adoção mais ou menos aleatória de teorias, conceitos, ideias e conceitos sem coerência, unidade e articulação teórica; ou $<<$ LITERAL >>, na qual a adesão a determinadas teorias aparece nominalmente expressa no Quadro 20 (Apêndice B).

A fim de conhecermos o grau de adesão à BNCC no nível apresentado aos professores (SACRISTÁN, 2000), após a adequação realizada pelas Secretarias de Educação, estabelecemos duas unidades de significação a partir de Bardin (2009): i) temas favoráveis à prescrição; e ii) temas favoráveis à orientação, para as quais atribuímos os sinais <<MAIS >>; ou <<MENOS>> que designam, respectivamente, "próximos" ou "distantes" aos sentidos de prescrição ou de orientação.

Os temas favoráveis à prescrição aludem à noção de um currículo enquanto produto, algo dado a ser seguido, estruturado em resultados pretendidos e hiper centrado no protagonismo do aluno. Os temas favoráveis à orientação remetem a um processo de construção coletiva do currículo diante das especificidades locais, fortalecidos pela autonomia docente, gestão democrática e pelo projeto políticopedagógico da unidade escolar.

Desse modo, a análise de conteúdo por categorias nos permitiu o desmembramento do discurso e o posterior (re)agrupamento em categorias, que subsidiaram inferências e interpretações dos discursos curriculares na atribuição dos graus Alto, Médio e Baixo a partir da valoração <<MAIS>> ou <<MENOS>> 
concedida aos "temas favoráveis à prescrição" e "temas favoráveis à orientação", sendo:

a) $<<$ MAIS $>>$ prescrição e $<<$ MENOS $>>$ orientação = ALTO grau de adesão à Base;

b) $<<$ MENOS $>>$ prescrição e $<<$ MAIS $>>$ orientação = BAIXO grau de adesão à Base; e

c) <<MAIS >> prescrição e <<MAIS >> orientação = MÉDIO grau de adesão à Base.

Aspectos detalhados no capítulo 5, sintetizados no Quadro 18.

\subsection{Estado do Conhecimento}

O estado do conhecimento se caracteriza como procedimento de levantamento do conhecimento produzido em teses, dissertações, artigos, livros, documentos que dialogam com o nosso objeto de estudo, contribuindo, dessa forma, para a estruturação dos eixos para a pesquisa.

Para Silva e Borges (2018, p. 1693), o estado do conhecimento não se restringe à mera metodologia de pesquisa, "[...] trata-se do próprio domínio empírico da teoria". Por isso, caracteriza-se como um item teórico-metodológico que possibilita não apenas conhecer as percepções dos pesquisadores expressas nos trabalhos científicos, revisar os campos de estudos acerca das temáticas, mas também "[...] demonstrar em quais sentidos elas avançaram e quais elementos ainda podem ser explorados."17

Realizamos as buscas entre os dias 13 e 17/08/2019, na base de dados da Biblioteca Digital Brasileira de Teses e Dissertações do Instituto Brasileiro de Informação em Ciência e Tecnologia (BDTD/IBICT), por conter as pesquisas de 2019, diferente do banco da CAPES e da UnB que disponibilizam somente os trabalhos de 2018.

O recorte temporal deste estado do conhecimento compreende o período de 2015 a 2019, anos de início da elaboração da BNCC e de início da implementação da BNCC El/EF nas unidades da Federação. Obtivemos o quantitativo de 172 (cento

17 Idem, Ibidem. 
e setenta e dois) trabalhos ao aplicar o termo indutor: BASE NACIONAL COMUM CURRICULAR, sendo 141 (cento e quarenta e uma) dissertações e 31 (trinta e uma) teses. Em seguida, aplicamos os filtros: Currículo >> Política educacional >> Trabalho pedagógico.

Capturamos o quantitativo de 11 (onze) dissertações e 5 (cinco) teses, totalizando 16 (dezesseis) produções para uma análise pormenorizada, porquanto corroboram os constructos epistemológicos dos eixos desta pesquisa. Ativemo-nos a dissertações e teses por se caracterizarem estudos orientados, dos quais se originam alguns artigos científicos. O percurso teórico-metodológico dos trabalhos está sintetizado no Quadro 14. 
Quadro 14 - Síntese teórico-metodológica de dissertações e teses

\begin{tabular}{|c|c|c|c|c|c|}
\hline Autor/a & Título & Método & Instrumentos & Lentes teóricas & Titulação \\
\hline $\begin{array}{l}\text { AGOSTINI, Camila } \\
\text { Chiodi (2017) } \\
\text { (Dissertação - } \\
\text { UFFS/SC) }\end{array}$ & $\begin{array}{c}\text { AS ARTES DE GOVERNAR O } \\
\text { CURRÍCULO DA EDUCAÇÃO INFANTIL: } \\
\text { A BASE NACIONALCOMUM } \\
\text { CURRICULAR EM DISCUSSÃO } \\
\end{array}$ & $\begin{array}{l}\text { Estudos culturais Foucault } \\
\text { (1979). }\end{array}$ & $\begin{array}{l}\text { Análise documental. Bricolagem e } \\
\text { articulação de conceitos } \\
\text { Paraíso(2012). }\end{array}$ & $\begin{array}{l}\text { Teorias pós-críticas } \\
\text { Silva (1996); Popkewitz (2011). }\end{array}$ & $\begin{array}{l}\text { Mestra } \\
\text { interdisciplinar } \\
\text { em Ciências } \\
\text { Humanas. }\end{array}$ \\
\hline $\begin{array}{l}\text { MOREIRA, } \\
\text { Damares de } \\
\text { Oliveira, (2017) } \\
\text { (Dissertação - } \\
\text { UFC/CE) }\end{array}$ & $\begin{array}{c}\text { PEDAGOGIA DAS COMPETÊNCIAS E } \\
\text { ESCOLAS ESTADUAIS DE EDUCAÇÃO } \\
\text { PROFISSIONAL DO CEARÁ: formando } \\
\text { para o mercado }\end{array}$ & $\begin{array}{c}\text { Pesquisa qualitativa } \\
\text { Materialismo Histórico } \\
\text { Dialético } \\
\text { Marx e Engels (2007, 2010) } \\
\text { Marx (2008, 2009, 2010, } \\
\text { 2013). } \\
\end{array}$ & $\begin{array}{l}\text { Estudo de caso com abordagem } \\
\text { bibliográfica, documental e de } \\
\text { campo }\end{array}$ & $\begin{array}{c}\text { Teorias críticas } \\
\text { Frigotto (2010); Duarte (2003); Vigotsky } \\
\text { (2000); Sousa Junior (2010); Lessa (2012); } \\
\text { Poyer (2007); Saviani (1991, 2013); Saviani e } \\
\text { Duarte (2012); Nosella (2002); Kuenzer } \\
\text { (1995); Ramos (2006); Romanelli (2006); } \\
\text { Shiroma; Moraes; Evangelista (2007). }\end{array}$ & $\begin{array}{l}\text { Mestra em } \\
\text { Educação }\end{array}$ \\
\hline $\begin{array}{l}\text { HELENO, Carolina } \\
\text { Ramos (2017) } \\
\text { (Dissertação - } \\
\text { UEFS/BA) }\end{array}$ & $\begin{array}{l}\text { CONTRIBUIÇÃO À CRÍTICA DA BASE } \\
\text { NACIONAL COMUM CURRICULAR: a } \\
\text { máscara do conformismo na educação } \\
\text { do Banco Mundial }\end{array}$ & $\begin{array}{l}\text { Método dialético e histórico } \\
\text { de pesquisa. Triviños } \\
\text { (1987). }\end{array}$ & $\begin{array}{c}\text { Revisão bibliográfica. } \\
\text { Análise de Conteúdo } \\
\text { Bardin (1970); e categorias } \\
\text { metodológicas (KUENZER, 1998) } \\
\text { da totalidade e contradição. } \\
\end{array}$ & $\begin{array}{c}\text { Materialismo Histórico Dialético } \\
\text { Marx (1857-8; 1980); Lukács (1967); Enguita } \\
\text { (1993). }\end{array}$ & $\begin{array}{l}\text { Mestra em } \\
\text { Educação }\end{array}$ \\
\hline $\begin{array}{l}\text { ARAÚJO, Macilene } \\
\text { Pereira (2017) } \\
\text { (Dissertação - } \\
\text { UEPB/PB) }\end{array}$ & $\begin{array}{l}\text { TEIAS CURRICULARES E ENSINO DE } \\
\text { BIOLOGIA: reflexões com base nas } \\
\text { questões do ENEM a partir da } \\
\text { Argumentação }\end{array}$ & Pesquisa qualitativa & Análise documental & $\begin{array}{l}\text { Análise de Conteúdo Bardin (1970). } \\
\text { Triangulação Dias (2008). }\end{array}$ & $\begin{array}{l}\text { Mestra em } \\
\text { Ensino de } \\
\text { Ciências e } \\
\text { Educação } \\
\text { matemática. }\end{array}$ \\
\hline $\begin{array}{l}\text { NAKAD, Fabricio } \\
\text { Abdo (2017) } \\
\text { (Dissertação- } \\
\text { FGV/SP) }\end{array}$ & $\begin{array}{c}\text { DESAFIOS PARA A IMPLEMENTAÇÃO } \\
\text { DA BASE NACIONAL COMUM } \\
\text { CURRICULAR }\end{array}$ & $\begin{array}{l}\text { Teorias Top-Down, Bottom- } \\
\text { Up, Combined Approach de } \\
\text { implementação de políticas } \\
\text { Públicas Hill; Hupe (2002); } \\
\text { Cerna (2013). }\end{array}$ & $\begin{array}{l}\text { Análise de Benchmarking, } \\
\text { avaliação comparativa }\end{array}$ & $\begin{array}{l}\text { Teorias Top-Down, } \\
\text { Bottom-Up, Combined Approach de } \\
\text { implementação de políticasPúblicas Hill; Hupe } \\
\text { (2002); Cerna (2013). }\end{array}$ & $\begin{array}{l}\text { Mestre em } \\
\text { Gestão e } \\
\text { Políticas } \\
\text { Públicas. }\end{array}$ \\
\hline $\begin{array}{l}\text { OLIVEIRA, Rodrigo } \\
\text { Batista (2018) } \\
\text { (Dissertação - } \\
\text { USP/SP) } \\
\end{array}$ & $\begin{array}{l}\text { O CURRÍCULO DE MATEMÁTICA NO } \\
\text { ESTADO DE SÃO PAULO (2008): uma } \\
\text { construção histórica }\end{array}$ & Pesquisa qualitativa & Entrevista semiestruturada & $\begin{array}{c}\text { História Oral Temática } \\
\text { Meihy (1996); Gaertner; Baraldi (2008); } \\
\text { Garnica (2003). }\end{array}$ & $\begin{array}{l}\text { Mestre em } \\
\text { Ciências. }\end{array}$ \\
\hline $\begin{array}{l}\text { FONSECA, Daniel } \\
\text { José R. (2018) } \\
\text { (Dissertação - } \\
\text { UFG/GO) } \\
\end{array}$ & $\begin{array}{l}\text { ANÁLISE DISCURSIVA SOBRE A } \\
\text { BASE NACIONAL COMUM } \\
\text { CURRICULAR }\end{array}$ & $\begin{array}{l}\text { Pesquisa qualitativa. } \\
\text { Abordagem teórico- } \\
\text { metodológica genealógica; } \\
\text { Foucault (2008). } \\
\end{array}$ & $\begin{array}{l}\text { Análise bibliográfica. } \\
\text { Análise documental }\end{array}$ & Foucault (1999, 2001, 2007, 2008, 2016). & $\begin{array}{l}\text { Mestre em } \\
\text { Educação. }\end{array}$ \\
\hline $\begin{array}{l}\text { SILVA, Vanessa } \\
\text { (2018) } \\
\text { (Dissertação - } \\
\text { UFP/RS) }\end{array}$ & $\begin{array}{l}\text { BASE NACIONAL COMUM } \\
\text { CURRICULAR: uma análise crítica do } \\
\text { texto da política }\end{array}$ & $\begin{array}{l}\text { Abordagem qualitativa } \\
\text { crítica Minayo (2001). }\end{array}$ & $\begin{array}{c}\text { Análise bibliográfica } \\
\text { Análise documental } \\
\text { Boweet al. (1992); Ball (1994); } \\
\text { Mainardes (2006). }\end{array}$ & Análise de Conteúdo Bardin (2011). & $\begin{array}{l}\text { Mestra em } \\
\text { Educação. }\end{array}$ \\
\hline
\end{tabular}

Fonte: Elaborado pela autora (2019) a partir das dissertações e teses. 
Quadro 14 - Síntese teórico-metodológica de dissertações e teses (continuação)

\begin{tabular}{|c|c|c|c|c|c|}
\hline Autor/a & Título & Método & Instrumentos & Lentes teóricas & Titulação \\
\hline $\begin{array}{c}\text { COSTA, Raquel } \\
\text { (2018) } \\
\text { (Dissertação- } \\
\text { UNESPAR/PR) } \\
\end{array}$ & $\begin{array}{l}\text { ESTADO, POLÍTICAS DE EDUCAÇÃO E } \\
\text { ENSINO: em debate a Base Nacional } \\
\text { Comum Curricular (2015-2017) }\end{array}$ & $\begin{array}{l}\text { Materialismo Histórico } \\
\text { Dialético }\end{array}$ & $\begin{array}{c}\text { Estudos bibliográficos Pesquisa } \\
\text { documental }\end{array}$ & $\begin{array}{l}\text { Materialismo Histórico } \\
\text { Dialético Marx e Engels }(1984,1998)\end{array}$ & $\begin{array}{l}\text { Mestre em } \\
\text { Ensino. }\end{array}$ \\
\hline $\begin{array}{l}\text { SILVA, Ana Paula } \\
\text { G. V. (2018) } \\
\text { (Dissertação- } \\
\text { UFG/GO) }\end{array}$ & $\begin{array}{l}\text { O CURRíCULO REFERÊNCIA DA REDE } \\
\text { ESTADUAL DE EDUCAÇÃO DE GOIÁS: } \\
\text { implicações nas atividades de } \\
\text { professores de ciências }\end{array}$ & $\begin{array}{l}\text { Pesquisa qualitativa } \\
\text { Materialismo Dialético }\end{array}$ & $\begin{array}{l}\text { Análise documental } \\
\text { Entrevista semiestruturada }\end{array}$ & $\begin{array}{l}\text { Análise de Conteúdo } \\
\text { Bardin (2011); } \\
\text { Franco (2012); } \\
\text { Triviños (2009). }\end{array}$ & $\begin{array}{l}\text { Mestra em } \\
\text { Educação. }\end{array}$ \\
\hline $\begin{array}{l}\text { CIERVO, Tássia } \\
\text { Joana R. (2019) } \\
\text { (Dissertação- } \\
\text { UNISINOS/RS) } \\
\end{array}$ & $\begin{array}{c}\text { A CENTRALIDADE DAS } \\
\text { COMPETÊNCIAS SOCIOEMOCIONAIS } \\
\text { NAS POLITICAS CURRICULARES } \\
\text { CONTEMPORÂNEAS NO BRASIL }\end{array}$ & $\begin{array}{c}\text { Pesquisa qualitativa } \\
\text { investigativa Gallian (2016); } \\
\text { Cellard (2012). }\end{array}$ & Análise documental & $\begin{array}{l}\text { Pesquisa documental interpretativa Cellard } \\
\text { (2012). }\end{array}$ & $\begin{array}{l}\text { Mestra em } \\
\text { Educação. }\end{array}$ \\
\hline $\begin{array}{l}\text { REIS, Geovana. } \\
\quad(2015) \\
\text { (Tese - UFG/GO) }\end{array}$ & $\begin{array}{l}\text { A GESTÃO DO CURRÍCULO ESCOLAR } \\
\text { NA REDE MUNICIPAL DE ENSINO DE } \\
\text { GOIÂNIA: entre "obrigações" } \\
\text { curriculares e práticas "autônomas" }\end{array}$ & $\begin{array}{l}\text { Pesquisa qualiquantitativa. } \\
\text { Análise dos dados } \\
\text { quantitativos Software } \\
\text { Statistical Package for } \\
\text { Social Science for Windows. }\end{array}$ & $\begin{array}{l}\text { Estudo de caso ampliado } \\
\text { Questionário de pesquisa }\end{array}$ & $\begin{array}{l}\text { Bourdieu }(1893,1989,1996,1999,2009) ; \\
\text { Lopes }(2002,2004,2011) ; \text { Moreira (1995; } \\
\quad \text { 1998, 1999, 2002, 2004, 2007); }\end{array}$ & $\begin{array}{l}\text { Doutora em } \\
\text { Educação. }\end{array}$ \\
\hline $\begin{array}{l}\text { SOUZA, Kleber Luiz } \\
\text { G. M. (2016) } \\
\text { (Tese - UFRN/RN) }\end{array}$ & $\begin{array}{c}\text { CONSENSOS E ASSIMETRIAS NAS } \\
\text { POLÍTICAS CURRICULARES PARA A } \\
\text { DISCIPLINA DE HISTÓRIA NO ENSINO } \\
\text { MÉDIO BRASILEIRO (1998-2012) }\end{array}$ & $\begin{array}{l}\text { Estudos Historiográficos. } \\
\text { Análise de Conteúdo } \\
\text { Bardin (1977). }\end{array}$ & $\begin{array}{l}\text { Estudos Comparativos, } \\
\text { Conceituais e Procedimentais }\end{array}$ & $\begin{array}{l}\text { Ball e Mainardes (2011); Chervel (1990); } \\
\text { Freitas }(2005,2007,2010)\end{array}$ & $\begin{array}{l}\text { Doutor em } \\
\text { Educação. }\end{array}$ \\
\hline $\begin{array}{c}\text { COSTA, Vanessa } \\
\text { do Socorro S. } \\
(2018) \\
\text { (Tese-PUC/SP) }\end{array}$ & $\begin{array}{c}\text { BASE NACIONAL COMUM } \\
\text { CURRICULAR COMO POLÍTICA DE } \\
\text { REGULAÇÃO DO CURRÍCULO, DA } \\
\text { DIMENSÃO GLOBAL AO LOCAL: O que } \\
\text { pensam os professores? }\end{array}$ & $\begin{array}{l}\text { Pesquisa qualitativa Bogdan } \\
\text { e Biklen (1994); Chizzotti } \\
\text { (2014). }\end{array}$ & $\begin{array}{l}\text { Pesquisas } \\
\text { bibliográfica/documental } \\
\text { Pesquisa de campo } \\
\text { Grupo focal }\end{array}$ & Ciclo de Políticas Ball $(2001,2014)$. & $\begin{array}{l}\text { Doutora em } \\
\text { Educação. }\end{array}$ \\
\hline $\begin{array}{l}\text { SANTANA, Pio de } \\
\text { Sousa (2019) } \\
\text { (Tese - UNESP/SP) }\end{array}$ & $\begin{array}{c}\text { A TRAJETÓRIA DO CURRÍCULO DE } \\
\text { ENSINO DE ARTES NA EDUCAÇÃO } \\
\text { BÁSICA BRASILEIRA DURANTE O } \\
\text { SÉCULO XX: documentos } \\
\text { mantenedores da desigualdade no } \\
\text { acesso à educação escolar }\end{array}$ & $\begin{array}{c}\text { Teoria da Educação } \\
\text { Teoria Crítica de Currículo e } \\
\text { da escola de Frankfurt } \\
\text { Marcuse (1979); Silva } \\
(1994,2015) ; \text { Freire (1982, } \\
\text { 2004, 2005); Saviani (1997, } \\
\text { 2010, 2011, 2012, 2013, } \\
\text { 2014). }\end{array}$ & $\begin{array}{l}\text { Levantamento } \\
\text { bibliográfico/documental }\end{array}$ & $\begin{array}{l}\text { Teoria da Educação } \\
\text { Teoria Crítica de Currículo e da escola de } \\
\text { Frankfurt; Marcuse (1979); Silva (1994, 2015); } \\
\text { Freire (1982, 2004, 2005); Saviani (1997, } \\
\text { 2010, 2011, 2012, 2013, 2014). }\end{array}$ & $\begin{array}{l}\text { Doutor em } \\
\text { Artes. }\end{array}$ \\
\hline $\begin{array}{l}\text { MARTINS, Adriana } \\
\text { dos Reis (2019) } \\
\text { (Tese - UNESP/SP) }\end{array}$ & $\begin{array}{c}\text { CURRÍCULO DE ARTE NA EDUCAÇÃO } \\
\text { DE TEMPO INTEGRAL DE UMA } \\
\text { ESCOLA DE PALMAS/TO: uma } \\
\text { percepção institucional e dos } \\
\text { professores } \\
\end{array}$ & $\begin{array}{l}\text { Pesquisa qualitativa Minayo } \\
\text { (2014). }\end{array}$ & $\begin{array}{l}\text { Pesquisa de campo } \\
\text { Entrevista semiestruturada }\end{array}$ & $\begin{array}{c}\text { Teoria Crítica } \\
\text { Análise qualitativa dos dados } \\
\text { Alves; Silva(1992); Apple (2006); Giroux } \\
\text { (1986); Silva (2007). }\end{array}$ & $\begin{array}{l}\text { Doutor em } \\
\text { Artes. }\end{array}$ \\
\hline
\end{tabular}

Fonte: Elaborado pela autora (2019) a partir das dissertações e teses. 
As palavras-chave das pesquisas selecionadas confirmam as categorias erigidas previamente, dispostas no Quadro 15.

\section{Quadro 15 - Palavras-chave nas categorias analíticas}

\begin{tabular}{|c|c|}
\hline Categorias & Palavras-chave \\
\hline $\begin{array}{c}\text { Política Pública } \\
\text { educacional e curricular }\end{array}$ & $\begin{array}{l}\text { Estado. Agentes Públicos e Privados. Neoliberalismo. Pós-modernidade. } \\
\text { Pós-estruturalismo. Globalização. Banco Mundial. Governança da } \\
\text { educação. }\end{array}$ \\
\hline $\begin{array}{r}\text { Concepção de } \\
\text { e de Cur }\end{array}$ & $\begin{array}{c}\text { Currículo, Teorias curriculares, T } \\
\text { Políticas educacionais, Refo }\end{array}$ \\
\hline $\begin{array}{c}\text { Organização do Trabalho } \\
\text { Pedagógico }\end{array}$ & $\begin{array}{l}\text { Pedagogia das Competências. Pedagogia Histórico-Crítica. Trabalho } \\
\text { Pedagógico. Competências cognitivas. Competências e Habilidades. } \\
\text { Competências socioemocionais. Educação Infantil. Ensino Fundamental. }\end{array}$ \\
\hline
\end{tabular}

Fonte: Elaborado pela autora (2019).

Na categoria Políticas Públicas educacional e curricular, destaca-se a permeabilidade do Estado a atores públicos e privados, nacionais e transnacionais, sociais e econômicos presentes na formulação, na regulamentação e na implementação da BNCC. Esse instrumento de ação pública está assentado nas lógicas de natureza gerencial e privatizantes da Organização para a Cooperação e Desenvolvimento Econômico (OCDE), da Organização das Nações Unidas para a Educação, a Ciência e a Cultura (UNESCO) e do Banco Mundial. Nesses estudos, a globalização, a crise estrutural do capital constitui a ambiência da governança global que delineia o projeto de educação nacional quando da construção e homologação das BNCC.

Agostini (2017) ressalta o investimento estatal neoliberal para a Educação Infantil presente na BNCC, objetivada pela escolarização precoce como forma de preparar, cada vez mais cedo, um tipo específico de criança para a vida competitiva e econômica. Essa análise discursiva é partilhada por Fonseca (2018), que evidencia no documento procedimentos de poder que enquadram a infância sob linhas de normalidade e disciplina. Ciervo (2019) denominou isso capitalismo emocional, para se referir à centralidade das competências socioemocionais nas políticas curriculares atuais, que secundariza o conhecimento escolar em busca de sujeitos empresários de si, autônomos, resilientes e competentes para as demandas do século XXI.

Nesse âmbito de Política para o Novo Milênio, Costa V. (2018) analisa a tessitura de construção da BNCC El/EF em seus aspectos macro, meso e micro. 
Desses, identificam-se diversos conflitos e disputas de poder econômico, ideológico e político entre os atores globais que, por sua vez, impactaram o contexto nacional. Heleno (2017) faz uma análise crítica ao receituário de políticas públicas do Banco Mundial e assevera que a BNCC se conforma à manutenção do status quo, pois alija a classe trabalhadora e de cor à compreensão da realidade pelo esvaziamento teórico da categoria cidadania.

Essas pesquisas contribuíram para a compreensão de como os atores impactam as representações e instituições, as quais operam os processos e os resultados. Esses resultados, conforme Lascoumes e Le Galès (2012), são os efeitos decorrentes da realização das políticas públicas, os quais não se encerram com a materialização da BNCC, ao contrário, abrem inúmeras novas agendas que confrontam outras realidades no contexto da prática da ação social.

Por meio da categoria Concepção de Educação e de Currículo foi possível revisitar os pressupostos das teorias educacionais e das teorias não críticas, críticas e pós-críticas de currículo presentes em propostas curriculares de alguns estados brasileiros. Essas perspectivas nem sempre ficam claras nos documentos, assim como na Base, nos quais não há, explicitamente, adesão a alguma teoria de currículo.

A tese de Santana (2019) aborda o ensino de Arte no século XX, tema que acompanha a oficialização curricular desse componente influenciado, inicialmente, pela teoria tradicional e, em seguida, pela teoria crítica da década de $1990 \mathrm{com}$ as normatizações da LDBEN. Essa disciplina foi excluída na primeira versão da Base, porém reinserida na versão final. $O$ currículo de Arte da educação integral no Tocantins constitui a tese de Martins (2019), que o identificou como dialético, emancipatório e inclusivo. A autora reafirma, ainda, a concepção de currículo como artefato sociocultural e histórico. Silva V. (2018) analisou as concepções de educação e de currículo presentes na BNCC, elucidou o campo conceitual sobre currículo, articulou-o com as esferas políticas, econômicas e sociais nas escalas macro e micro e traçou um percurso curricular brasileiro desde a década de 1990, por meio dos parâmetros e diretrizes existentes.

O estudo de Oliveira (2018) descreve o movimento de acomodação entre o currículo prescrito e o currículo vivido de Matemática do estado de São Paulo em 2008, nos aspectos de distribuição, seleção e fragmentação de conteúdos, objetivos e recursos. Esse objeto se assemelha ao de Silva A. (2018), que pesquisou o 
currículo do estado de Goiás quando da implementação do Currículo Referência. Evidenciou-se divergência entre 0 conceito de currículo dos documentos normatizadores e a concepção dos docentes vinculada aos conteúdos dos livros didáticos. Já a tese de Souza (2016), por meio das análises conceituais de políticas educacionais, currículo e conteúdos, investigou os consensos e assimetrias conceituais no currículo de História para o ensino médio. O autor averiguou que as matrizes do ENEM pautam o currículo dessa disciplina. Por outro lado, Reis (2015) buscou articular os conceitos de teorias de currículo, políticas curriculares e gestão do currículo para analisar a execução do currículo pelos professores, a qual mostrou-se relativamente autônoma ante as regulações políticas.

Os "novos conceitos" de educação integral, de expressões como projeto de vida, autonomia, protagonismo, tecnologia e do modo de organização dos conhecimentos escolares nos ajudam a identificar as concepções de educação e de currículo presentes nos referenciais curriculares.

$\mathrm{Na}$ categoria Organização do Trabalho Pedagógico vemos como ter uma base de estrutura normativa e prescritiva curricular obrigatória repercute no trabalho pedagógico da escola e do professor em sala de aula. Fica ainda suscetível à autonomia das escolas de definirem a forma dessa organização em seus projetos político-pedagógicos, que tanto pode estar aliada a uma perspectiva crítica e de qualidade socialmente referenciada ou a estruturas hegemônicas de reprodução social.

A dissertação de Nakad (2017), organizada pelo Movimento pela Base Nacional Comum, aborda modelos de implementação em países que adotaram uma base curricular comum, como Austrália, Chile, Estados Unidos (Califórnia e Nova York) e Cingapura. Essas experiências foram categorizadas segundo os desafios relacionados à implementação e, ao final, algumas recomendações são elencadas para o enfretamento dessas questões aqui no Brasil.

Compreender os processos de construção e implementação da BNCC constitui, do mesmo modo, a pesquisa de Costa R. (2018) em que competências e habilidades presentes na ideia do aprender a aprender se supõem capazes de solucionar as discrepâncias sociais por meio de conteúdos disciplinares.

Nessa corrente, a Pedagogia das Competências, objeto da pesquisa de Moreira (2017), propicia, segundo a autora, o dualismo que consiste em uma educação para os ricos e outra para a classe trabalhadora. Isso reforça a 
necessidade de um modelo educacional mais justo que supere essa discrepância. Ainda em relação a competências e habilidades, Araújo (2017) propõe identificar possibilidades de aproximação entre a argumentação como modelo didático, o currículo de Biologia e a matriz de competências e habilidades do Exame Nacional do Ensino Médio (ENEM). Nessa proposta dialógica, os estudantes figuram como autores no processo de ensino-aprendizagem, e os professores, como mediadores.

Os pesquisadores questionaram 0 processo de produção da base, ressaltaram a necessidade de discussão e acompanhamento de questões atinentes aos currículos locais, à formação docente, infraestrutura, ao livro didático etc. Alguns trabalhos apresentaram perspectivas de solução e de resistência para os executores dessa política pública, realçando a expectativa que os institutos - projeto políticopedagógico, gestão democrática e currículo - representam para os profissionais da educação e para a comunidade escolar.

Desse modo, este estado do conhecimento nos propiciou o deslinde dos processos socioestatais ensejadores da reforma da educação básica em curso, dos contextos de produção dos textos da base e dos referenciais curriculares subnacionais e dos possíveis efeitos de um núcleo comum para a educação.

Dada a realidade curricular inédita brasileira de uma base comum, e a tenra adequação dos currículos dos estados e do DF a essa norma, não foram encontrados trabalhos que tratem das relações de aproximação ou distanciamento, entre as prescrições centrais da BNCC e as apropriações locais, fato que caracteriza o ineditismo desta pesquisa.

Afora esses trabalhos, trouxemos, ainda, o Relatório de análise de propostas curriculares de ensino fundamental e ensino médio (SAMPAIO, 2010), encomendado pelo MEC às secretarias de educação e o Relatório final: Currículos para os anos finais do ensino fundamental: modos de implantação, e usos (CENPEC, 2015), esta última referenciada na BNCC (BRASIL, 2016b; BRASIL, 2017b).

Ambas as pesquisas estudaram as propostas curriculares em âmbito estadual, distrital e municipal, cujo objetivo foi conhecer as escolhas curriculares desses entes federativos no uso da autonomia que lhes é conferida. Produziram um panorama curricular nacional desde a década de 1990 até 2014, período anterior à formulação da BNCC. 
O estudo de Sampaio (2010) propiciou um mapeamento nacional acerca: (i) da multiplicidade de documentos produzidos, evidenciou-se que alguns desses documentos não constituíam propostas curriculares; (ii) da observância às orientações oficiais centrais; (iii) dos objetivos e das intencionalidades dos sistemas e redes de ensino; (iv) das concepções teórico-pedagógicas e dos fundamentos da psicologia da aprendizagem que embasam as propostas curriculares; (v) da forma de organização do ensino, em ciclos ou em séries/ano; e (vi) da forma de organização do currículo, por áreas do conhecimento, eixos temáticos, blocos, disciplinas; e (vii) dos estados que não apresentaram propostas para o Ensino Fundamental e para o Ensino Médio.

A pesquisa do CENPEC (2015), por sua vez, buscou conhecer: a) a existência ou não de padrões no processo de renovação curricular dos entes federados; b) o que estava sendo proposto pelas escolas, em termos nacionais, no processo de (re)elaboração das propostas curriculares; c) as concepções que orientam os documentos curriculares para os anos finais do ensino fundamental; d) a forma pela qual os conteúdos dos componentes curriculares são abordados, além de classificar os modelos curriculares, sob diferentes denominações e características: "matriz curricular"; "currículo"; "proposta curricular"; e "diretrizes curriculares".

Desse modo, para além de um dado meramente quantitativo, o estado do conhecimento nos possibilitou, em articulação com os referenciais teóricos, consubstanciar os eixos epistemológicos e avançar na temática proposta, contribuindo, assim, com a produção de conhecimento científico acerca do tema. A seguir, apresentamos os fundamentos da pesquisa qualitativa, o caminho percorrido pelo problema e os procedimentos de construção e de análise dos dados. 


\section{A COMPLEXIDADE E A MULTIATORIALIDADE DA BNCC: ELEMENTOS PARA UMA SOCIOLOGIA POLÍTICA DA AÇÃO PÚBLICA}

Analisar as políticas educacionais sob o conceito de políticas públicas que tanto se aplica a um "comando que visa a resolver problemas em nome do bem comum" quanto a "um vasto espaço de negociação que envolve uma grande diversidade de atores privados e públicos" (LASCOUMES; LE GALĖS, 2012, p. 63) subsidia a sociologia política da ação pública.

Tal perspectiva supera a análise de políticas públicas estadocentristas, pois se interessa pelas regulações sociais desencadeadas pelas regulações políticas nas quais o Estado não é o único ator na efetivação de direitos sociais, uma vez que suas ações incidem sobre outros elementos interacionais que moldam as políticas públicas, a exemplo da BNCC como indutora da reforma da educação básica em curso e de inúmeras políticas educacionais e curriculares advindas dela.

A materialização da BNCC quase cinco décadas após a previsão de um "núcleo comum, obrigatório em âmbito nacional, e uma parte diversificada para atender, conforme as necessidades e possibilidades concretas, às peculiaridades locais" (Lei n. 5.692 de 11 de agosto de 1971, artigo $4^{\circ}$ ), recobre dinâmicas evolutivas e cognitivas complexas, e de multiatorialidade aqui analisadas sob 0 influxo da Sociologia Política da Ação Pública. Essa abordagem é conciliada por Muller e Surel (2002) ao entender que

[...] o Estado é hoje percebido no essencial através de sua ação, seja esta considerada como positiva ou negativa. Por isso mesmo, estudar a ação pública não consiste mais verdadeiramente (ver-se-á mesmo se esta questão não perdeu todo seu sentido) em refletir sobre o lugar e sobre a legitimidade do Estado, enquanto forma política abstrata, mas em compreender as lógicas implementadas nestas diferentes formas de intervenção sobre a sociedade, em identificar os modos de relação existentes entre atores públicos e privados e em compreender como a ação pública recobre as dinâmicas imprecisas e evolutivas da fronteira entre Estado e sociedade (MULLER; SUREL, 2002, p. 7).

Esses autores enfatizam a necessidade de estudarmos o fenômeno a partir das articulações entre a regulação política e a regulação social, entre o que é ou não conduzido pelas políticas públicas. Lentes assim nos permitem olhar para a BNCC como esse instrumento mediador da reforma educacional em tela. 
Neste capítulo, discutiremos algumas das principais características da Base Nacional Comum Curricular enquanto instrumento de Ação Pública na introdução, nas duas seções intituladas: Ambiência de normatizações e regulações políticosociais e Instrumentação da BNCC: arena de poder e construção de sentidos, e nas considerações iniciais. A relevância de se atentar para esse fenômeno se justifica pelo cenário curricular inédito de reforma da educação básica ensejado por um núcleo comum, analisado ante os vetores interacionais: atores; instituições; representações; processos e resultado de Lascoumes e Le Galès (2012).

Não há uma linearidade sequencial entre esses elementos não excludentes, uma vez que constituem componentes imensos de negociação e de poder nos quais os múltiplos atores socioestatais se posicionam, confrontam-se e estabilizam as representações globais, nacionais e locais de problemas e soluções por meio de formas de cooperação, normas e regras que são as instituições, além de formas de interação, atividades de mobilização que caracterizam os processos cujos efeitos constituem os resultados.

Nessa dinâmica complexa, imprevisível e heterogênea, as políticas afetam outras realidades e outras políticas que emergem no contexto de reformas educacionais nas quais o currículo é sempre alvo de reconfigurações e novas fórmulas. Segundo Sacristán (2000, p. 20)

De alguma forma, o currículo reflete o conflito entre interesses dentro de uma sociedade e os valores dominantes que regem os processos educativos. Isso explica o interesse da sociologia moderna e dos estudos sobre educação por um tema que é o campo de operações de diferentes forças sociais, grupos profissionais, filosofias, perspectivas pretensamente científicas, etc.

Simultaneamente, a BNCC diz do projeto de nação e de educação frente à agenda estatal e aos interesses dominantes, e envolve variados níveis de poder na readequação e implementação da política educacional e curricular locais, pois age como instrumento organizador entre o poder público e os demandatários das políticas educacionais em função de representações e valores.

A própria constituição da matriz referencial da BNCC, que direciona a reelaboração curricular das unidades federativas, constitui instrumentação da ação pública que modula as unidades objetivo/conteúdo, avaliação/método, capital/trabalho. Assim, a definição de instrumentação da ação pública nos remete 
[...] ao conjunto de problemas apresentados pela escolha e o uso de instrumentos (técnicas, formas de operar, dispositivos) que permitem materializar e operacionalizar a ação governamental. Trata-se de compreender, não apenas as razões que levam a escolher um instrumento em detrimento de outro, mas também verificar os efeitos produzidos por essas escolhas (LASCOUMES; LE GALÈS, 2012, p. 200).

Ou seja, a instrumentação se refere às estratégias de operacionalização realizadas nos espaços de sentido e examinadas na empiria que vinculam as políticas aos atores, às dinâmicas e aos processos de elaboração e implementação da política educacional tratada na seção seguinte.

\subsection{Ambiência de Normatizações e de Regulamentações Político-Sociais}

A ideia de um núcleo comum para a educação básica começa a se firmar na década de 1970, inspirada no debate acadêmico em prol da reformulação dos cursos de Formação de Educadores da década anterior, embora "[...] a primeira lei geral de ensino no Brasil, assinada por D. Pedro I e publicada a 15/10/1827, prescrevia um currículo mínimo para todo o país" (CURY et al., 2018, p. 21).

No entanto, esse propósito apenas se fortalece com a promulgação da Constituição Federal de 1988 (CF/88), considerada cidadã, na qual as relações entre o Estado e a sociedade civil foram dinamizadas pela ampliação dos direitos sociais e de mecanismos de participação democrática, cooperativa e fiscalizatória pelos cidadãos por meio de conselhos públicos e autônomos, orçamentos participativos, consultas públicas e audiências públicas. Entendemos "sociedade civil", dentre os vários sentidos, como "[...] uma arena de liberdade (pelo menos potencial) fora do Estado, um espaço de autonomia, de associação voluntária e de pluralidade e mesmo conflito, garantido pelo tipo de 'democracia formal' que se desenvolveu no Ocidente" (WOOD, 2003).

No âmbito da Educação Básica, a Carta Magna dispõe acerca da descentralização fiscal, do controle social pela adoção de uma gestão democrática no plano local e eleva os municípios aos demais entes federados - União, estados e Distrito Federal -, atribuindo-Ihes capacidade de auto-organização, administração e 
de legislarem em matérias específicas. Em tese, a constituição cidadã traz a noção de competência comum e de regime de colaboração para viabilizar a articulação entre os entes federados. Porém, a atuação conjunta entre eles se apresenta, ainda, frágil na garantia do direito à educação. "Isso porque são desiguais a autonomia, o poder político na definição das normas, a capacidade de arrecadação, a obrigação na aplicação de recursos e as responsabilidades para a oferta da educação" (UNDIME, 2017, p. 30-31).

À União cabem ações normativas, indutivas e redistributivas de elaboração das diretrizes nacionais, das orientações técnicas das políticas educacionais para a adesão e a implementação pelos governos subnacionais e de assistência supletiva financeira aos entes da federação que dela precisarem. Este ente "[...] oferece menos de 1\% do total de matrículas na educação básica pública" (UNDIME, 2017, p. 33), caracterizando-se mais como apoiador do que como provedor da educação básica, e tem mecanismos legais, financeiros e de arbítrio assimétricos em relação aos demais entes, embora menores com o advento da $\mathrm{CF} / 88$ :

Havendo perdido recursos e poder, adotou a estratégia de simplesmente repassar encargos, principalmente aos municípios. Além disso, em termos estruturais, não é simples montar parcerias com os governos subnacionais pelo país afora, seja pela dificuldade de relacionamento com governantes oposicionistas, seja pela necessidade de arbitrar as divergências entre os membros da própria coalizão governista, que apoiam o presidente, mas são adversários no plano local (ABRUCIO, et al., 2013, p. 141).

Ante esse desafio, a União, por meio do Ministério da Educação, seu órgão de coordenação, e pelo Conselho Nacional de Educação, seu eixo normativo, optou pela padronização curricular como forma de instituir um federalismo cooperativo, no qual os entes autônomos pactuam uma descentralização, mas também vinculam-se pela necessidade de ações coordenadas próprias do regime de colaboração, mantendo um jogo intergovernamental que requer participação e capacidade de negociação aos estados e municípios.

Ao Distrito Federal e aos estados estão destinados, prioritariamente, o ensino fundamental e médio e, por serem dotados de autonomia política e fiscal, "[...] assumem funções de gestão de políticas públicas ou por própria iniciativa, ou por adesão a algum programa proposto por outro nível mais abrangente de governo, ou 
ainda por expressa imposição constitucional" (ARRETCHE, 2000, p. 47), assim como os municípios.

Os municípios ganharam autonomia, adquiriram capacidade de organização de seus sistemas de ensino e atuam, predominantemente, na educação infantil e no ensino fundamental. Muitos deles, contudo, não tinham condições administrativas, técnicas, financeiras ou políticas para usufruir do novo status. Somente em 2003, com a Lei $\mathrm{n}^{\circ} 10.832$ (BRASIL, 2003), os municípios passaram a receber integralmente a quota do Salário-Educação conforme o número de alunos matriculados, receita que o ente federado estado administrava sozinho.

Antes, porém, a Lei de Diretrizes e Bases, nำ 9.394/96, nos artigos 8ํa 20 , estabeleceu uma maior descentralização ao instituir a organização dos Sistemas de Ensino dos entes federados, em cumprimento ao artigo 211 da CF/88. Todavia, as normas de cooperação para a consecução de políticas sociais que congreguem objetivos comuns não foram, ainda, regulamentadas por leis complementares, como previsto no artigo 23, parágrafo único, fato que compromete o bem-estar e o equilíbrio do desenvolvimento dos Sistemas de Ensino.

Do mesmo modo, o Sistema Nacional de Educação, previsto no Plano Nacional de Educação (2014-2024), que seria responsável "[...] pela articulação entre os sistemas de ensino, em regime de colaboração, para a efetivação das diretrizes, metas e estratégias do Plano Nacional de Educação" (BRASIL, 2014b, artigo 13) não foi aprovado pelas casas legislativas.

Como alternativa a essas lacunas em questões de colaboração e cooperação federativa, surgem as formas de associativismo territorial e os sistemas de Políticas Públicas, segundo Abrucio et al. (2013). No primeiro arranjo, a cooperação entre territórios ocorre em mais de um nível de governo, nacional e/ou internacional, em que esses se articulam, horizontal e verticalmente, por convênios e consórcios de direito público e de direito privado para a provisão de serviços nas áreas de transporte, saneamento básico, meio ambiente, saúde, turismo, educação. Isso ocorre a exemplo dos Arranjos de Desenvolvimento da Educação (ADE) realizados por alguns municípios a partir de 2000; e por conselhos estaduais de secretários para a elaboração de ações conjuntas acerca das políticas comuns que vêm do nível central. "Porém, é interessante que o sucesso dessa empreitada se vincula mais à construção de governanças de multi-level govenance do que à política pública 
educacional em si, ou então a um associativismo inato dos governos locais" (GRIN e ABRUCIO, 2017, p. 41).

No segundo ajuste, predomina o conceito de Sistema de Políticas Públicas que pretende combinar a coordenação e a indução da União com a autonomia dos entes subnacionais. O caso emblemático no Brasil é o Sistema Único de Saúde (SUS), no qual "[...] tratou-se de combinar o princípio descentralizador, com prioridade à municipalização, com um sentido de política nacional, presente nas ideias centrais de hierarquização e regionalização da prestação dos serviços" (ABRUClO et al., 2013, p. 151).

A permeabilidade estatal, desses movimentos descentralizadores, permite que o Estado se desloque da posição central de produtor e executor de políticas públicas para o de regulador de serviços públicos. Esse traspassamento movimenta a absorção de práticas do setor privado pelo poder público, transfere o serviço de estratos escolares obrigatórios da Educação Básica pública para aquele setor, numa lógica neoliberal de privatização do público caracterizada pela "[...] capacidade, perene no tempo, de ser atravessado por outros atores e interesses, sem necessariamente ser motivado por razões exclusivas de ordem econômica" (TRIPODI e SOUSA, 2018, p. 250). Uma "competição administrada" de responsabilização e meritocracia na administração pública é, do mesmo modo, justificativa para essa porosidade estatal segundo as autoras e que dialogam com as tendências administrativas: Nova Gestão Pública e Governança em rede.

A Nova Gestão Pública introduz na esfera pública "[...] métodos e ferramentas típicas do setor privado, enfatizando a criação de padrões de medidas de performance, o gerenciamento por resultados e o foco no cliente" (TRIPODI e SOUSA, 2018, p. 235) para que o Estado possa aumentar sua governança que não se confunde com governo, conforme as autoras apud Rhodes (1996), pois

[...] o próprio conceito de governança supõe uma mudança na noção de governo enquanto aquele ator central responsável pela produção de políticas pública, conhecido como Estado-providência. Isso porque, no cerne da definição de governança estaria postulado o princípio de superação da dicotomia Estado e mercado, via introdução de novo padrão de cooperação entre atores sociais, que estão situados fora do aparelho estatal, materializando-se enquanto sociedade civil (TRIPODI e SOUSA, 2018, p. 254). 
Governança se manifesta nas formas de coordenação multiníveis em um Estado metamórfico ${ }^{18}$, dada a habilidade estatal de se transmutar entre Estado providência, do bem-estar social, liberal, neoliberal para atender a agenda governamental. Essas metamorfoses são sentidas principalmente na escola, onde diversas políticas, não apenas educacionais, forçosamente desembocam, por exemplo os programas "Bolsa Família", "Mais Educação", merenda escolar, transporte escolar, que são antes políticas assistencialistas e/ou sociais que educacionais e curriculares, por isso, as políticas e as escolas são também metamórficas.

A onda de reformas educacionais pelo mundo se inicia na década de 1980 sob a lógica do neoliberalismo ${ }^{19}$ econômico de países membros da Organização para a Cooperação e Desenvolvimento Econômico (OCDE), influenciadas pelo Movimento Global de Reforma da Educação (GERM - Global Education Reform Movement). O GERM conduziu as "[...] reformas nos Estados Unidos, em muitas regiões da Austrália, no Canadá, no Reino Unido, e em alguns países escandinavos, e em um número cada vez maior de países em desenvolvimento." (SHALBERG, 2018, n.p.). Descrito por este autor como "uma nova ortodoxia educacional", o Movimento se articula em torno da descentralização estatal, concorrência, padronização de metas curriculares e resultados, ênfase na literacia e numeracia, de vouchers para pais escolherem a escola dos filhos, do accountability enquanto prestação de contas e responsabilização - inspeção, recompensa ou punição.

No Brasil, a liberalização econômica do governo Collor (1990-1992) consolidou a entrada de políticas neoliberais no país propiciadoras da Reforma do Aparelho do Estado executada por Bresser-Pereira, durante o primeiro mandato (1995-1998) de Fernando Henrique Cardoso (FHC), a qual construiu os alicerces para a reforma educacional ao garantir "[...] a esse aparelho maior governança, ou seja, maior capacidade de governar, maior condição de implementar as leis e políticas públicas", transferindo os serviços "[...] não-exclusivos para a propriedade pública não-estatal, e a produção de bens para o mercado e para a iniciativa privada" (BRASIL, 1995b, p. 56).

18 Termo apresentado por Doriana Daroit no II Workshop sobre Ação Pública para o desenvolvimento democrático 2019 - FACE/UnB.

19 Termo que remete ao Consenso de Washington, realizado em 1989, quando institutos de economia discutiram reformas necessárias para a América Latina. 
Desde então, houve a: i) universalização do acesso ao ensino fundamental, que chegou a 97\% de cobertura para as crianças de 7 a 14 anos; ii) implementação dos sistemas de informação e de produção de indicadores educacionais pelo Censo Escolar; iii) implantação dos sistemas de avaliação: Provão, Sistema de Avaliação da Educação Básica (Saeb), Exame Nacional do Ensino Médio (ENEM), cujos resultados serviram de subsídio para orientar a elaboração dos Parâmetros Curriculares Nacionais (1997, 1998, 1999, 2002); e iv) instituição do Fundo de Manutenção e Desenvolvimento do Ensino Fundamental e de Valorização do Magistério (FUNDEF) dentre outros avanços.

Entre continuidades e descontinuidades, o primeiro mandato do governo Lula (2003-2006) foi marcado muito mais por permanências que por rupturas, herdou "[...] uma reforma educacional de longo alcance e complexidade, que durante os dois mandatos do governo que o precedeu - FHC - mudou os rumos da educação brasileira" (OLIVEIRA, 2009, p. 198). Já no segundo mandato do presidente Lula (2007-2010), houve correções significativas em relação ao ensino médio e ações de fortalecimento da Educação Superior.

Quanto à priorização do ensino fundamental em oposição ao ensino médio no governo de $\mathrm{FHC}$, tanto em relação à universalização quanto ao financiamento, foi contornada pelo governo Lula com a Lei no. 12.061/2009 (BRASIL, 2009b), que universalizou o ensino médio gratuito, seguida pela Emenda Constitucional no 59/2009, que alterou o artigo 208 da CF e instituiu a "[...] educação básica obrigatória e gratuita dos 4 (quatro) aos 17 (dezessete) anos de idade, assegurada inclusive sua oferta gratuita para todos os que a ela não tiveram acesso na idade própria" (BRASIL, 2009a). Nesse mesmo sentido, a conversão do FUNDEF para o Fundo de Manutenção e Desenvolvimento da Educação Básica e de Valorização dos Profissionais da Educação (FUNDEB) passou a abarcar as três etapas da educação básica: educação infantil, ensino fundamental e ensino médio.

Com a edição do Decreto no 5.154/2004 (BRASIL, 2004), em revogação ao Decreto $n$ ํ. 2.208/1997 (BRASIL, 1997), resgatou-se o modelo de educação profissional técnica de nível médio e de educação profissional tecnológica de graduação e pós-graduação, e políticas setoriais para o acesso à educação superior pública e privada foram implementadas. Desse modo, entre 2002 e 201020, o

20 Dados do MEC, segundo Araújo (2013, p. 168). 
número de campi de universidades federais saltou de 43 (quarenta e três) para 230 (duzentos e trinta), mais que duplicando o número de pessoas com ensino superior completo no país. Isso significa "[...] um impacto imediato e significativo não somente na vida cultural, mas também no comércio e nos serviços locais" (ARAUJO, 2013, p. 168). Para Heleno (2017, p. 19), a medida permitiu a transferência de alta soma de recursos públicos à rede privada de ensino, o que acabou "[...] facilitando as condições de mercantilização e de direção política dos empresários, visando a conciliação entre classes antagônicas".

Ante essa conjuntura, o GERM e a Declaração Mundial sobre Educação para Todos $^{21}$, é fundada, no Brasil, em 2006, a organização da sociedade civil Todos Pela Educação - Fundações Lemann e Roberto Marinho, os institutos Unibanco e Natura, o Itaú BBA dentre outros ${ }^{22}$ - com o propósito de "[...] promover a mobilização de atores-chave do cenário nacional pela Educação".

Mais à frente, em 2013, o grupo não governamental Movimento pela Base ${ }^{23}$, composto pelo Todos Pela Educação e por empresários, políticos, empresas educacionais, institutos e fundações privadas, mídia, editoras e pesquisadores alinhados à reforma privatizante da educação pública, conhecidos como os "reformadores empresarias da educação"24, empreenderam esforços para a construção e implementação de uma Base Nacional Comum.

Em abril de 2015, a Secretaria de Assuntos Estratégicos da Presidência da República do governo de Dilma Rousseff, lançou o programa: Pátria Educadora: a qualificação do Ensino Básico como obra de construção nacional (BRASIL, 2015a), em que se conclama o engajamento de toda a sociedade na "transformação nacional" via educação. O documento traz uma análise conjuntural da educação brasileira em que alguns aspectos sociopolíticos e econômicos sustentam a corresponsabilização de professores, diretores, alunos, universidades pelas desventuras atuais nessa área. Reconhece-se o valor das lógicas de eficiência empresarial para o campo educacional e alude-se a uma reorientação do paradigma curricular e pedagógico por meio da base nacional comum que abandonará o enciclopedismo raso que tradicionalmente marca nosso ensino. Não se contentará,

21 Ação conjunta entre o Banco Mundial (BM), o Fundo das Nações Unidas para a Infância (UNICEF), o Programa das Nações Unidas para o Desenvolvimento (PNUD) e a Organização das Nações Unidas para a Educação, a Ciência e a Cultura (UNESCO).

22 Disponível em: https://www.todospelaeducacao.org.br/pag/quem-somos/\#bloco_67. Acesso em: 12 set. 2019.

23 Disponível em: http://movimentopelabase.org.br/quem-somos/. Acesso em 12 set. 2019.

24 Termo cunhado por Diane Ravitch (2011) para designar o corporate reformers nos Estados Unidos e traduzido por Luiz Carlos de Freitas. 
porém, em colocar enciclopédia menor - conjunto de conteúdos consagrados - no lugar da enciclopédia maior. Dará a capacitações primazia sobre conteúdos. E na maneira de tratar conteúdos preferirá o aprofundamento seletivo à superficialidade abrangente (BRASIL, 2015a, p. 9).

Assim, esse ideário foi se justificando, mais pela negação do que pela afirmação, no entendimento segundo o qual uma base comum curricular e suas implicações seriam a panaceia para todos os males da educação nacional. Como tal, seu conteúdo não poderia advir de soluções educacionais locais, social e culturalmente referenciadas da comunidade escolar. Assim, havia que editar a Portaria ํㅡ 592/2015 (BRASIL, 2015b) pelo Ministério da Educação (MEC), dois meses depois, para instituir a comissão de especialistas indicados pelos partidos políticos aliados, pelo Conselho Nacional de Secretários de Educação (CONSED) e pela União Nacional dos Dirigentes Municipais de Educação (Undime) a fim de elaborar a proposta da Base Nacional Comum Curricular.

Visão corroborada pelos que acreditam ser a Base o instrumento conformador da identidade nacional, para eles, o "[...] comum, básico e mínimo, de um lado, evitam a dispersão e, de outro, efetivam a articulação do uno e do múltiplo por meio de uma ação organizada e permanente do Estado Nacional" (BRASIL, 2014a, p. 5).

A Base é estudada por nós como instrumento da ação pública indutor de outras políticas e mediador entre a sociedade política e a sociedade civil, lente que nos permite observar o processo de elaboração e implementação da Base nos liames das ações entre os múltiplos atores, os quais afetam e são afetados pelas representações (valores, símbolos) e instituições (normas, procedimentos), que, por sua vez, moldam os processos (coalizões, mobilizações) e resultados (efeitos).

Na próxima seção, abordaremos as dinâmicas e os dispositivos operacionais, característicos da instrumentação da ação pública, que, segundo Cruz (2017, p. 79), "[...] está no centro da governamentalidade, despontando as táticas para dar conta dos múltiplos nexos e finalidades da arte de governar", a exemplo da audiência pública na qual estivemos presentes, tratada a seguir. 


\subsection{Instrumentação da BNCC: Arena de Poder e Construção de Sentidos}

A construção da Base se inicia, em 2015, durante o segundo mandato da presidenta Dilma Rousseff e se bifurca na Base Nacional Comum Curricular da Educação Infantil e do Ensino Fundamental (BNCC El/EF) (BRASIL, 2016b), homologada em 20/12/2017, e na Base Nacional Comum Curricular do Ensino Médio (BNCC/EM) (BRASIL, 2017b), homologada em 14/12/2018 no governo do presidente Michel Temer, dado o impedimento da presidenta.

A BNCC El/EF foi apresentada à sociedade nas versões I (set. 2015, 302p.), II (maio 2016, 652p.) e III (abr. 2017, 396p.) e reacendeu os debates em torno da concepção de infância, da pedagogia da escolarização e dos direitos e objetivos de aprendizagem.

A versão I trouxe a ideia de Campos de Experiência, inspirados na escola italiana, definidos como "[...] conjunto de práticas que articulam saberes e os fazeres das crianças com os conhecimentos já sistematizados da humanidade" (1 $1^{a}$ versão, $p$. 20) e doze objetivos de aprendizagem elencados como princípios, que na $3^{\text {a }}$ versão aparecem como dez competências gerais. Denominada "consulta pública", esta versão recebeu, segundo o MEC, mais de doze milhões de contribuições oriundas de escolas, professores e organizações da sociedade civil, quantitativo que equivale a "[...] um pouco mais de $10 \%$ dos internautas" 25 (HELENO, 2017, p. 117), sendo considerados internautas apenas os $58 \%$ da população que têm acesso à internet.

Essas contribuições oriundas da sociedade civil repercutiram na versão II, que se apresenta mais analítica, duplicada em número de páginas e com um caráter norteador. Nesta, a Educação Infantil abarca: a) bebês (0 a 18 meses); b) crianças bem pequenas ( 19 meses a 3 anos e 11 meses); e c) crianças pequenas (4 anos a 5 anos e 11 meses). Além disso, os objetivos de aprendizagem estão organizados em tabelas conforme o esperado em cada faixa etária.

Na versão III há alterações importantes ${ }^{26}$ de fundamentação pedagógica e de organização da Educação Infantil ao criar grupos de competências pessoais e sociais, cognitivas e comunicativas, sobre as quais as práticas docentes devem ser estruturadas e ser objeto de constante monitoramento e avaliação, visto que "[...]

25 Percentual construído a partir de pesquisa realizada pelo Comitê Gestor da Internet no Brasil (CGI), o Centro Regional de Estudos para o Desenvolvimento da Sociedade da Informação (Cetic) e o Núcleo de Informação e Coordenação do Ponto BR (NIC).

26 Mudança do grupo de redatores das versões anteriores. 
reitera a importância e necessidade de imprimir intencionalidade educativa às práticas pedagógicas na Educação Infantil, tanto na creche quanto na pré-escola" (BRASIL, 2016b, p. 8). Desse modo, antecipa-se a expectativa de alfabetização completa das crianças para o segundo ano, em oposição ao terceiro ano, previsto no Pacto Nacional pela Alfabetização na Idade Certa (PNAIC), alterando, assim, a formação de subjetividades das crianças e a atuação docente sobre elas.

Por sua vez, a BNCC/EM foi completamente impactada pela Reforma do Ensino Médio, perpetrada pela Medida Provisória 746/2016 do então presidente Michel Temer, questionada por Ações Diretas de Inconstitucionalidade (ADI) ${ }^{27}$ por inconstitucionalidade formal e vícios materiais, entretanto, não tendo sido julgadas pelo Supremo Tribunal Federal antes de sua conversão na Lei no 13.415/2017b pelas casas legislativas.

O Novo Ensino Médio está estruturado em: i) um Módulo Comum, disposto em quatro áreas do conhecimento, quais sejam: linguagens e suas tecnologias; matemática e suas tecnologias; ciências da natureza e suas tecnologias; e ciências humanas e sociais aplicadas, sendo obrigatórias, nos três anos de ensino médio, língua portuguesa e matemática; e ii) Itinerários Formativos, compostos de um itinerário de formação técnica e profissional, e de quatro itinerários das mesmas áreas de conhecimento do Módulo Comum para satisfazer o "projeto de vida" do estudante: mercado de trabalho ou Educação Superior.

Essa dualidade encolhe o currículo e obsta o acesso dos educandos das escolas públicas aos conhecimentos clássicos produzidos histórica e coletivamente pela humanidade (SAVIANI, 2012), chegando ao ponto de tornar obrigatórios, nos três anos do ensino médio, português e matemática, e facultativas disciplinas como filosofia e sociologia, as quais, contudo, são fundantes para o desenvolvimento de uma consciência crítica sobre o mundo e o homem em substituição a uma consciência ingênua (FREIRE, 2017). É opcional, também, a formação geral básica em física e química, por exemplo, campos essenciais para um letramento científico ${ }^{28}$ mínimo e de estímulo aos jovens por formação em Ciências, Tecnologias, Engenharias e Matemática (STEM - Science, Technology, Engineering and

27 ADI5599 (PSOL) e ADI5604 do CNTE.

28 Para o PISA (2015), "Letramento científico é a capacidade de se envolver com as questões relacionadas com a ciência e com a ideia da ciência, como um cidadão reflexivo" (BRASIL, 2019a). 
Mathematics), áreas primordiais para o desenvolvimento técnico-científico e econômico do país.

Em síntese, a Lei o 13.415/2017 foi veementemente contestada pela comunidade escolar e entidades acadêmicas e científicas do país presentes nas audiências públicas organizadas pelo $\mathrm{CNE}$, onde os atores sociais participam como voz, e não como voto, nos processos de legitimação das propostas governamentais.

Em 14 de setembro de 2018, observamos presencialmente a audiência pública realizada em Brasília ${ }^{29}$, organizada pelo Conselho Nacional de Educação (CNE), ao qual coube deliberar sobre a BNCC/EM elaborada pelo MEC, redigir um parecer e um Projeto de Resolução que, após a homologação do Ministro da Educação, foi convertido em norma nacional.

O CNE é órgão de Estado, integrante do Ministério da Educação, composto por 24 Conselheiros, sendo doze na Câmara de Educação Básica e doze na Câmara de Educação Superior, nomeados pelo Presidente da República. Pela primeira vez na história deste Conselho, o Decreto de nomeação e recondução de conselheiros expedido por uma chefe de Estado - presidenta Dilma - foi revogado por outro - presidente Temer. Tal ato gerou indignação de entidades educacionais expressa em Nota ao CNE, na qual se registra que "[...] a pluralidade de posições e de concepções no interior do CNE foi desfeita com a desconsideração, datados de 29 de março deste ano, de nomes indicados pelas entidades que historicamente eram consultadas, ainda que parcialmente atendidas" (ANPED, 2018). Desse modo, quatro conselheiros que debateram a BNCC/EM não puderam votar, devido a sua substituição dois meses antes da votação.

Este colegiado tem atribuições deliberativas, normativas e de assessoramento ao ministro, instituídas pela Lei oㅜ 9.131/1995 (BRASIL, 1995a) e organizou audiências públicas nas cinco regiões do país a fim legitimar a BNCC/EM enviada pelo MEC. As audiências públicas realizadas em Florianópolis, Fortaleza e Brasília, a interrompida de São Paulo e a não realizada do Pará, canceladas após manifestações e muito tumulto, sinalizam a complexidade do tema.

$\mathrm{O}$ auditório para o evento, embora destinado à região Centro-Oeste, dispunha de apenas 240 lugares, para os quais as inscrições estiveram disponíveis por quatro dias no sítio eletrônico do CNE. Muitas pessoas que não conseguiram se inscrever

29 Vídeo da audiência pública disponível em: www.portal.mec.gov.br. Acesso em: 15 set. 2018. 
foram impedidas de entrar e se aglomeraram no portão de entrada. Com isso, sucederam gritos de ordem e interrupções pelos participantes no interior do auditório que exigiam a liberação para os não inscritos, pois havia lugares vagos, até que o presidente da sessão, Eduardo Deschamps, autorizou a entrada dos demais.

Em outra situação, uma estudante do ensino médio da região Norte interpelou o presidente sobre o fato de haver na Mesa diretora apenas conselheiros do sexo masculino para tratar de Educação, área majoritariamente composta por mulheres e sem paridade neste colegiado. Dessa vez, Eduardo Deschamps passou a condução dos trabalhos para a conselheira Márcia Aguiar.

Representantes de federações, associações científicas e de classe, organizações estudantis, de pais e mães se manifestaram para denunciar, vigorosa e criticamente, a forma antidemocrática da reforma do ensino médio, as reais intenções mercadológica e utilitária da medida e as consequências nefastas para os filhos da classe operária e para a classe trabalhadora docente em oposição à manutenção dos interesses do capital e das elites dirigentes. Brados veementes foram desferidos durante toda a sessão: "EDUCAÇÃO NÃO É MERCADORIA!"; "PEDAGOGIA É UNIÃO, NÃO DEIXA O MEC ACABAR COM A EDUCAÇÃO!"; "ABAIXO A BNCC!"

Os temas mais abordados se referiram à exclusão de disciplinas essenciais do módulo comum, com efetivo prejuízo à interdisciplinaridade, à criticidade e ao letramento científico; à privatização da educação básica com a previsão de cumprimento dos itinerários formativos a distância e/ou por meio de estágios; à necessidade de investimentos em infraestrutura, formação docente e valorização da carreira.

A maioria dos participantes reivindicaram a revogação da Lei ํo 13.415/2017, a não aprovação da BNCC/EM e solicitaram mais tempo e espaço para o debate nacional. Segue o posicionamento explícito de três ${ }^{30}$ dos doze conselheiros que compõem a Câmara de Educação Básica e usaram da palavra no período da tarde:

[...] eu tomei a decisão de renunciar a essa presidência agora no mês de julho pra poder me expressar com maior veemência, clareza e objetividade as posições que eu tenho em relação a essa proposta de reforma do ensino médio [...] temos que revogar e devolver ao MEC, pois o CNE não pode melhorá-la (Conselheiro 1).

30 Conselheiros não reconduzidos ao cargo, desligados do CNE em outubro de 2018. 
[...] votamos contrariamente à BNCC do ensino fundamental, porque discordávamos de uma série de questões. [...] falo da forma de se entender como se dá o processo democrático, ele é entendido como foi entendido pelo Ministério da Educação, numa verticalidade [...] 0 Conselho Estadual de Educação do Rio de Janeiro, do qual tenho a honra de ser presidente, não apoia a base (Conselheira 2).

Estamos vivenciando uma reforma da Educação nacional, uma reforma silenciosa, porque vem mediante modificações em várias instâncias, em várias organizações que compõem a estrutura mesmo da nossa Educação e não tem sido discutida com todos os que estão diretamente interessados e os que são responsáveis por isso. [...] daí a minha posição contrária à BNCC (Conselheira 3).

Outros conselheiros ressaltaram a importância das audiências públicas ao processo democrático como oportunidade de manifestação da sociedade:

A BNCC é tão importante para todos nós, todos nós que somos professores, todos nós que trabalhamos com a Educação que é impossível fazer entre quatro paredes. Acho que tem que envolver a sociedade, tem que trazer a sociedade para esse conselho para que todos nós ouçamos essa sociedade. (Conselheira 4).

Queria destacar a importância da escuta e agradecer a todas as pessoas [...]. Há contribuições bastante relevantes e dizer da importância, em que pesem todas as questões que foram colocadas a respeito de maior tempo, a importância da fala e da escuta nesta que é a última audiência pública, e ela acontecer tem significado muito grande para todos nós que estamos envolvidos com a Educação (Conselheira 5).

[...] esse momento é muito raro, muito importante [...] essa abertura de um espaço de diálogo com a sociedade, mesmo que não seja possível estar nas 27 unidades da Federação e nos 5560 municípios, não podemos deixar de reconhecer o esforço deste Conselho de estar presente nas 5 regiões do País para tentar ouvir, ainda, algumas críticas, algumas sugestões e contribuições ao texto encaminhado pelo MEC (Conselheiro 6).

A configuração das audiências comprometeu, precisamente, a perspectiva democrática, na medida em que o CNE não contemplou as demandas críticas da comunidade acadêmica, educacional e escolar, inclusive os pedidos por mais tempo e espaço para o debate. Essas divergências foram expressas, também, nos documentos entregues ao CNE pelas entidades ligadas à educação, durante o evento. 
O Quadro 16 apresenta o posicionamento de entidades ${ }^{31}$ ligadas à Educação acerca da proposta da BNCC/EM enviada pelo MEC, expresso nos documentos entregues ao CNE.

Quadro 16 - Posicionamento sobre a aprovação da BNCC/EM enviada pelo MEC

\begin{tabular}{|l|c|c|}
\hline \multicolumn{1}{|c|}{ Entidade } & Documento & $\begin{array}{c}\text { Posicionamento sobre } \\
\text { a BNCC/EM }\end{array}$ \\
\hline $\begin{array}{l}\text { 1. Associação Nacional pela Formação dos } \\
\text { Profissionais da Educação (ANFOPE) }\end{array}$ & Carta & CONTRÁRIO \\
\hline 2. Sociedade Brasileira de Física (SBF) & Carta & CONTRÁRIO \\
\hline 3. Associação de Geógrafos Brasileiros (AGB) & Carta & CONTRÁRIO \\
\hline 4. União Marista do Brasil (UMBRASIL) & Carta & ABSTENÇÃO \\
\hline $\begin{array}{l}\text { 5. Comitê Nacional pelo Ensino Religioso no } \\
\text { Brasil }\end{array}$ & Manifesto & ABSTENÇÃO \\
\hline $\begin{array}{l}\text { 6. Federação Nacional das Escolas } \\
\text { Particulares (FENEP) }\end{array}$ & Carta & ABSTENÇÃO \\
\hline 7. Instituto Federal Baiano (IFB) & Relatório & CONTRÁRIO \\
\hline $\begin{array}{l}\text { 8. Sindicato dos Professores do Ensino Oficial } \\
\text { do Estado de São Paulo (APEOESP) }\end{array}$ & $\begin{array}{c}\text { Abaixo- } \\
\text { assinado }\end{array}$ & CONTRÁRIO \\
\hline $\begin{array}{l}\text { 9. Sociedade Brasileira para o Progresso da } \\
\text { Ciência (SBPC) }\end{array}$ & Carta & CONTRÁRIO \\
\hline
\end{tabular}

Fonte: Elaborado pela autora (2019) a partir de CNE. Disponível em:

http//portal.mec.gov.br/component/content/article?id=70301. Acesso em: 26 out. 2018.

Não houve qualquer registro expresso de aprovação da BNCC/EM nos documentos da região Centro-Oeste. As entidades que se abstiveram são todas do segmento de escolas particulares e religiosas.

Nesse sentido, vale evidenciar que essas dissensões se encontram, minimamente, representadas no Conselho que votou pela aprovação da Base, como se pode ler na Declaração de Voto do Conselheiro José Francisco Soares, relator do processo:

O dissenso faz parte do processo do debate acadêmico e social. Defender uma posição divergente da maioria é também uma forma digna de participar do debate. Foi o papel que me coube desta vez. Não consegui convencer os colegas dos riscos educacionais e

31 Para conhecer os efeitos da BNCC/EM para a Organização do Trabalho Pedagógico (OTP), apontados pelas entidades, ver nosso artigo: SILVA, Edileuza Fernandes; PAULA, Alessandra Valéria de. BNCC DO ENSINO MÉDIO E TRABALHO PEDAGÓGICO: propostas da audiência pública de Brasília. Currículo sem Fronteiras, v. 19, p. 992-1010, set./dez. 2019. 
sociais que vi na solução por eles advogada para o Ensino Médio, nem me convencer que estes riscos não existem. Por isso dei o meu voto contra. Registro, entretanto, que os debates ocorreram em um clima de respeito mútuo. (BRASIL, 2018c).

Nesse contexto de representações, quadros de ação e mobilizações, os atores políticos da Comissão Bicameral/Conselho Pleno do CNE, com seus interesses, recursos e estratégias, aprovaram a BNCC/EM ainda em 2018, sem nenhum voto contra ${ }^{32}$.

Deste modo, e com a homologação do Ministro da Educação, a Base tornouse norma nacional obrigatória a todas as escolas, redes e sistemas de ensino médio, públicos e privados do país, e constitui "um documento de caráter normativo que define o conjunto orgânico e progressivo de aprendizagens essenciais que todos os alunos devem desenvolver ao longo das etapas e modalidades da Educação Básica (BRASIL, 2016b, p. 8).

Concluídas as fases de aprovação e homologação, as secretarias de educação, com a aprovação dos respectivos Conselhos de Educação (CE), adequaram seus currículos à Base. Essas circunstâncias reacenderam as discussões acerca de a Base ser ou não currículo, de como incorporá-la localmente e da autonomia curricular das unidades escolares e dos docentes, que são os verdadeiros decisores curriculares.

A despeito das declarações do MEC, reforçadas pelo CNE (BRASIL, 2018b) e pela UNDIME (UNDIME, 2017, p. 60), de que "A Base não é currículo", Freitas (...) enfatiza que

[...] só adotando uma concepção instrumental do que seja um "currículo" (restrito à definição do como fazer) é que se pode afirmar que a BNCC não é currículo. Mesmo assim, nota-se que a BNCC através do material didático também chegará ao "como fazer". Portanto, na prática, a BNCC definiu competências, habilidades (incluindo seu sequenciamento, ano em que devem ser dadas), currículo mínimo, avaliações e materiais didáticos. O que sobrou para o magistério criar? (FREITAS, 2018b, n.p.).

Conformamos nosso entendimento ao que nos preleciona Sacristán (2000) para asseverarmos que a Base é currículo sim, no mínimo em âmbito prescrito, uma

32 O Conselheiro relator do processo deu o voto contra no Parecer, porém, contraditoriamente, se absteve na votação em plenário. 
vez que, ao determinar os conteúdos e os métodos pedagógicos via mínimo comum, transferem-se os códigos pedagógicos, fundamentalmente, para os materiais didáticos, que caracterizam as regulamentações de um currículo prescrito. "É um modelo indireto muito potente, que, embora não determine o que se pode fazer nas aulas, ordena e depura os conteúdos que nelas entram" (SACRISTÁN, 2000, p. 122).

Esse foi um problema fundamental nesta pesquisa que investiga a forma pela qual as unidades da Federação atualizaram seus currículos ante as prescrições da BNCC, discutindo o processo de elaboração dessa política pública, as concepções teóricas e pedagógicas de educação e de currículo incorporadas nas propostas subnacionais e o grau de adesão à BNCC.

O Currículo em Movimento do Distrito Federal (DISTRITO FEDERAL, 2018), por exemplo, demonstra aparentemente baixo grau de alinhamento à BNCC, pois manteve as concepções teórico-pedagógicas e de currículo da primeira versão do documento de 2014, garantiu a oferta de língua estrangeira em vez de apenas língua inglesa, uma vez que Brasília abriga as embaixadas e, há 45 anos, o sistema público de Centro Interescolar de Línguas (CIL). Além disso, organizou o trabalho pedagógico por objetivos/conteúdos e não por habilidades/competências. Tais opções sinalizam estar a Secretaria de Estado de Educação do Distrito Federal (SEEDF) e o Conselho de Educação atentos à realidade local e à historicidade do seu documento curricular que remonta os debates iniciados em 2010 pelos profissionais da educação.

As análises extensivas às UF constam dos capítulos seguintes.

\subsection{Considerações Iniciais}

A abordagem histórica dos alicerces propiciadores da Base, analisados mediante os elementos interacionais da sociologia política da ação pública, permitenos dizer que a educação brasileira figura como uma questão de Estado e não de governo, na medida em que o projeto de nação e de educação iniciado na década de 1990, em linhas gerais, foi mantido, perpassou os governos de FHC, Lula, Dilma e Temer, e se concretizou em 2017. 
A BNCC supera a finalidade explícita de ser um conjunto orgânico e progressivo de aprendizagens essenciais, está estruturada em torno de políticas de avaliações censitárias, de responsabilização e controle. Essas, alinhadas à agenda global de reformas educacionais e às recomendações neoliberais da OCDE e do Fundo das Nações Unidas para a Infância (UNICEF), atravessaram décadas de governos brasileiros denominados de centro-esquerda, de esquerda e de direita.

Nessa perspectiva, a Base é o instrumento técnico-social que propicia a descentralização estatal e induz inúmeras novas agendas que demandam arranjos de cooperação entre os entes federados nas temáticas: universalização do ensino médio, formação docente, avaliação da aprendizagem e do sistema, material didático entre outros. Essas são arenas imensas, marcadas por divergências e disputas entre os diversos atores socioestatais que não se findam com a materialização da Base e dos currículos das unidades da Federação. 


\section{EPISTEMOLOGIAS EDUCACIONAIS E DE CURRÍCULO PRESENTES NOS DOCUMENTOS CURRICULARES}

Educação e currículo constituem campos investigativos interdependentes e híbridos, porém, distintos. Uma concepção de educação leva a uma de currículo e vice-versa; todavia, há contradições entre as finalidades da educação e o conhecimento a ser disponibilizado pela escola.

As teorias educacionais contêm: teoria geral da educação; História da Educação e das disciplinas escolares e não escolares; Sociologia da Educação; Psicologia da Educação e Filosofia da Educação, ou seja, em linhas gerais, abarca tudo que se busca descrever e propor para a Educação. Por sua vez, as teorias curriculares envolvem toda a organização do trabalho pedagógico, da construção do currículo na seleção dos conteúdos e das disciplinas, tempo/espaço, técnicas, avaliação, destinação e significação. Trata-se, em linhas gerais, da discussão aprofundada de como foi, está e poderá ser organizado o conhecimento.

Nesses domínios, importa conhecer os objetivos da educação, o papel da escola, a visão de mundo, sujeito e conhecimento presentes nas epistemologias que tanto podem tencionar a manutenção do status quo de grupos hegemônicos, quanto podem estar a serviço de um processo emancipador humano.

Historicamente, Educação e escola serviram para ocupar o tempo ocioso da nobreza, como ofício sacerdotal e para a proteção de jovens contra as tentações mundanas, para atender as demandas da industrialização, como espaço de formação de hábitos, socialização, equalização social e como elemento-chave de modernização da sociedade.

Neste capítulo, abordaremos as principais teorias e concepções de educação e de currículo presentes nos documentos curriculares das unidades da Federação para a Educação Básica induzidas pela Base Nacional Comum Curricular nas seções: Teorias e autores: (des)usos; e Cenário conceitual atual com o advento da BNCC. 


\subsection{Teorias e Autores: (DES)USOS}

Embora haja vários estudiosos que tratam sobre teorias e epistemologias da educação, optamos pelo professor e pesquisador Dermeval Saviani, porque suas ideias e proposições se alinham com a nossa análise.

Saviani (2012) analisa a Educação como instrumento de superação da marginalidade ou como fator de marginalização para classificar as teorias da educação em: i) não críticas, que contêm as Pedagogias Tradicional, Nova e Tecnicista; as teorias sobre educação denominadas; ii) crítico-reprodutivistas, nas quais não há propostas pedagógicas, mas dinâmicas de funcionamento da escola enquanto reprodutora do modo de produção capitalista e da sociedade de classes; e iii) críticas que aparentam ser revolucionárias, mas de fato são reacionárias, como a pedagogias do Aprender a Aprender. Em seguida, Saviani lança as bases para uma educação revolucionária veiculada à Pedagogia Histórico-Crítica, apta a dotar "[...] criticamente a escola como um instrumento capaz de contribuir para a superação do problema da marginalidade" (SAVIANI, 2012, p. 30).

Ignorância, inadaptação e ineficiência seriam as causas da marginalidade que as pedagogias tradicional, nova e tecnicista não conseguiram equacionar, pois seus eixos se deslocaram

[...] da questão pedagógica do intelecto para o sentimento; do aspecto lógico para o psicológico; dos conteúdos cognitivos para os métodos ou processos pedagógicos; do professor para o aluno; do esforço para o interesse; da disciplina para a espontaneidade; do diretivismo para o não diretivismo. (SAVIANI, 2012, p. 8).

Posteriormente, os estudos crítico-reprodutivistas sobre a educação, em nível de pós-graduação no Brasil da década de 1970, respaldados nas teorias do sistema de ensino como violência simbólica de Bourdieu e Passeron; na teoria da escola como aparelho ideológico de Estado de Althusser; e na teoria da escola dualista com Baudelot e Establet demonstraram que os marginalizados eram os desprovidos de capital econômico e cultural, ou seja, os dominados e explorado pela pedagogias hegemônicas burguesas. Assim, "[...] enquanto as teorias não-críticas pretendem ingenuamente resolver o problema da marginalidade por meio da escola sem jamais conseguir êxito, as teorias crítico-reprodutivistas explicam a razão do suposto fracasso" (SAVIANI, 2012, p. 30). 
Um pujante movimento de educadores que se opunham a continuar como reprodutores dos interesses dominantes instigou a criação de entidades associativas, organizações e mobilizações sociais no campo educacional em busca de pedagogias contra-hegemônicas em favor dos menos favorecidos economicamente.

O método freireano de alfabetização de adultos demonstra essa preocupação com os trabalhadores; contudo, suas ideias, ainda hoje, no Brasil, estão vinculadas, sobretudo, à Educação de Jovens e Adultos (EJA). O Documento Curricular de Roraima (2019, p. 520), por exemplo, evoca Paulo Freire somente para a EJA, pois conclui "[...] que o diálogo/linguagem, fenômeno humano é fator imprescindível para a construção do conhecimento, proporcionando aos jovens e adultos o domínio de códigos utilizados pelos opressores, em suas vidas, no ato de refletir e agir." Para as demais etapas e modalidades, adotou-se a pedagogia do Aprender a Aprender. Talvez porque as referências teóricas em Paulo Freire "[...] comportam um conjunto de autores que sugerem um diálogo com a filosofia dialética e com o marxismo" (SAVIANI, 2010, p. 331).

Entre 1978 e 1984, o professor Saviani ministrou a disciplina de teoria da educação para a primeira turma de doutorado da Pontifícia Universidade Católica de São Paulo (PUC/SP). Em tais circunstâncias, uma pedagogia crítica revolucionária foi formulada e várias teses foram defendidas, contribuindo "[...] como um importante marco inicial na construção da pedagogia histórico-crítica. Como se pode ver, já no início, essa pedagogia veio com a marca da construção coletiva" (MALANCHEN, 2016, p. 156). Lançada em 1983, a Pedagogia Histórico-Crítica está sintetizada da seguinte forma:

Numa síntese bastante apertada, pode-se considerar que a pedagogia histórico-crítica é tributária da concepção dialética, especificamente na versão do materialismo histórico, tendo fortes afinidades, no que se refere às suas bases psicológicas, com a psicologia histórico-cultural desenvolvida pela Escola de Vigotski. A educação é entendida como 0 ato de produzir, direta e intencionalmente, em cada indivíduo singular, a humanidade que é produzida histórica e coletivamente pelo conjunto dos homens. Em outros termos, isso significa que a educação é entendida como mediação no seio da prática social global. A prática social põe-se, portanto, como o ponto de partida e o ponto de chegada da prática educativa. Daí decorre um método pedagógico que parte da prática social em que professor e aluno se encontram igualmente inseridos, ocupando, porém, posições distintas, condição para que travem uma relação fecunda na compreensão e no encaminhamento da solução dos problemas postos pela prática social". (SAVIANI, 2010, p. 421). 
Desde então, essa perspectiva pedagógica tem respaldado estudos no campo da didática, da organização do trabalho pedagógico e do currículo, comumente associada à forma de resistência apta a superar o problema da marginalidade, na medida em que considera os dominados e as práticas sociais.

Em analogia a esses movimentos, os estudos curriculares organizados como "Documentos de identidade" por Tomaz Tadeu da Silva (2002) introduzem as teorias tradicionais, críticas e pós-críticas de currículo. A origem do campo é estadunidense, onde a palavra currículo apareceu pela primeira vez em 1902, na obra The child and the curriculum de John Dewey. Entretanto, suas formulações foram consideradas progressistas por dar muita importância à criança e serem pouco relevantes para as finalidades últimas da educação à época.

A abordagem aceita como marco da teoria tradicional é a produção de Bobbit The Curriculum, em 1918, reputada por igualar o sistema educacional ao sistema organizacional administrativo de Frederick Taylor, no qual a escolarização das massas deveria suprir as exigências industriais advindas do taylorismo e do fordismo. "Não havia por que discutir abstratamente as finalidades últimas da educação: elas estavam dadas pela própria vida ocupacional adulta" (SILVA, 2002, p. 23).

As questões atinentes aos objetivos da escola, à organização de práticas pedagógicas para a consecução desses objetivos e à avaliação surgem somente no pós-Segunda Guerra em 1949 com Basic principles of curriculum and teaching de Ralph Tyler, que questiona os objetivos educacionais e procura responder às questões por ele formuladas. Obra marcante por muitos anos, inspirou Robert F. Mager, em Preparing instructional objectives, em 1962, que impactou a formação e o exercício docente por muitas décadas.

Nas teorias críticas de currículo ressoam os movimentos políticos, sociais e culturais do Pós-Segunda Guerra Mundial em diferentes países, sob a influência do marxismo, dos estudos crítico-reprodutivistas sobre educação, da Escola de Frankfurt, da Nova Sociologia da Educação (NSE) e do movimento de Reconceptualização em reação às concepções burocráticas e administrativas de currículo na produção de desigualdades sociais.

A escola torna-se um espaço de defesa das massas populares contra as classes dominantes e de lutas no campo social e cultural. "Para as teorias críticas o 
importante não é desenvolver técnicas de como fazer o currículo, mas desenvolver conceitos que nos permitam compreender o que o currículo faz (SILVA, 2002, p. 30).

Neomarxistas e fenomenólogos estavam preocupados com as contradições atuais da escola que nasceu a partir do desenvolvimento do modo de produção capitalista, movidos por questões de "[...] como os diferentes tipos de organização do currículo estão ligados a princípios diferentes de poder e controle" (SILVA, 2002, p. 72), visto que os conhecimentos organizados em saberes escolares "[...] envolvem o que é considerado como conhecimento socialmente legítimo, não são de pouca significação para entendermos a posição cultural, econômica e política da escola" (APPLE, 2006, p. 40), eles representam as escolhas priorizadas pelo capital dominante, que adentram os espaços escolares e definem as particularidades do processo de ensino.

Essa tarefa corroborada pela NSE, que se dedicou a analisar aspectos do conhecimento intrinsicamente relacionados às estruturas sociais, econômicas e institucionais. Constituem, do mesmo modo, objeto da NSE os alunos e como eles pensam, agem e vivem. Henry Giroux sugere olhar o currículo na sua relação com temas atinentes a gênero, etnia, raça, sexualidade.

Essas temáticas estão comumente relacionadas às teorias Pós-Críticas de currículo, sustentadas na crença em uma nova era pós-moderna, pós-marxista e pós-estruturalista, em reação ao projeto de ser humano homogêneo e objetivo do lluminismo, rechaçado nos movimentos antibélicos, culturais e sociais do pós-guerra, nos quais identidade, alteridade e heterogeneidade ganham centralidade.

Na perspectiva pós-estruturalista, o currículo é "[...] concebido como verbo currere - privilegia o conceito de indivíduo nos estudos de currículo" (PINAR, 2016, grifos do autor), se interessa pelo processo de desconstrução derridiana dos "inúmeros binarismos de que é feito o conhecimento que constitui o currículo: masculino/feminino; heterossexual/homossexual; branco/negro; científico/não científico" (SILVA, 2002, p. 124) e pela significação entre saber e poder de análise foucaultiana.

A Linguística, especialmente as formulações de significante e significado, língua (la langue) e fala (la parole), signo e sistema semiológico de Saussure, Sapir e Jakobson, é a ciência que embasa o pós-estruturalismo corroborado por Kant, Durkheim, Lévi-Strauss dentre outros estruturalistas. 
Nos construtos linguísticos conscientes e inconscientes em que a linguagem constitui um sistema de diferenças, o signo remete a uma convenção social, logo, a uma estrutura instável. "É precisamente isso que teóricos pós-estruturalistas como Jacques Derrida vêm tentando dizer nos últimos anos. A linguagem vacila" (HALL e WOODWARD, 2000, p. 78), visto que depende de um processo de identidade e de diferença cultural para se efetivar.

Nominado multiculturalismo e tipificado como eixos transversais, esses temas passam a compor o currículo a partir dos anos de 1990, quando surgiram nos Parâmetros Curriculares Nacionais as temáticas das culturas minoritárias étnicoraciais, de gênero e sexualidade. À guisa de exemplificação, o Currículo do Piauí (2019, p. 35) traz quinze Temas Contemporâneos Transversais (TCT) "[...] para atender às novas demandas sociais e garantir que o espaço escolar seja um espaço cidadão", que comporta: educação financeira, fiscal, alimentar e nutricional; para o consumo e para a valorização do multiculturalismo nas matrizes históricas e culturais brasileiras, sem focar, contudo, em questões econômicas e de classes sociais para se pensar os problemas da educação e do currículo.

Sartre, em Crítica da Razão Dialética (2002), assevera não fazer sentido falar em uma era pós-moderna, pós-marxista, pois a objetividade do fenômeno - relações sociais constituídas pelo modo de produção capitalista - continua sendo efetiva nos termos fundamentais descritos por Marx e em escala planetária. Em relação aos limites conceituais em Marx, esses foram tratados pela Escola de Frankfurt ensejando discussões dialéticas acerca dos fenômenos sociais e já contemplando as minorias. Em outros termos, apresentar elementos novos, alterações dialéticas e fenômenos não lidos por uma epistemologia não deveria ser sinônimo de extermínio dessa.

Para Wood (1996), decretar o fim de metanarrativas, como a Teoria Social de Marx, torna o capitalismo invisível, propagado na ideia de impossibilidade de compreendê-lo criticamente. Então, o melhor a fazer é aproveitar suas benesses tecnológicas e de consumo. A autora afirma que o movimento deveria ser o oposto, pois

[...] esses processos reclamam uma explicação materialista. Uma compreensão materialista, constitui, ao contrário, passo essencial para liberar a cultura dos grilhões da mercantilização. Se o pósmodernismo nos diz alguma coisa, de uma maneira distorcida, sobre 
as condições do capitalismo contemporâneo, a ideia está em descobrir quais são exatamente essas condições, por que o são e qual o caminho a seguir a partir daí. A ideia, em outras palavras, é sugerir explicações históricas para tais condições, ao invés de apenas submeter-se a elas, consentindo em adaptações ideológicas. (WOOD, 1996, p. 125).

Retomar o debate acerca das teorias de currículo, reconhecer as contribuições das concepções críticas e pós-críticas à ideia de escola que os estudos sobre as revoluções do final do século XVIII trouxeram, reafirmar a não existência de uma teoria absoluta e perfeita, e posicionar-se por uma reflexão crítica da prática social tem sido a postura do historiador, pedagogo e curriculista ${ }^{33}$, Silva F. (2018, p. 14) justificada

[...] na necessidade de elaborar uma teoria curricular que prime pelo estudo das origens do campo, das políticas para o ensino, dos sujeitos implicados com a sua prática e das condições materiais, sociais, políticas, culturais, estéticas e religiosas para implantação de qualquer prática curricular. (SILVA F. 2018, p. 17).

Não obstante os dissensos entre os teóricos críticos e pós-críticos, a maior parte deles comunga da ideia de crítica à política da $\mathrm{BNCC}^{34}$ e à Pedagogia da Competências que "[...] põe no sujeito a culpa pelo fracasso das políticas públicas, que passa a ser visto como derivado de incapacidade individual de performar" (MACEDO, 2016, p. 51).

A autora assevera que o antagonismo apresentado na academia entre 0 conhecimento pragmático e o conhecimento em si, presente no espaço de debate da base nacional comum, "[...] naturaliza a ideia de currículo como controle, contribuindo para a hegemonização dessa significação" (MACEDO, 2016, p. 49).

Tem-se um sinal de que houve avanços em relação ao alerta que Michael Young fez no sentido de que essa discussão entre os teóricos de currículo, motivada pelos estudos culturais e por ideias filosóficas, não perdesse o objeto de estudo da teoria curricular que é o conhecimento, isto é, "[...] essencialmente aquilo que se

33 Termo convencionado para se referir a acadêmico cujo campo de estudo envolve, especialmente em nível stricto sensu, a História do currículo, Teoria Geral do Conhecimento, Teoria de Currículo, política curricular, programas e disciplinas escolares. Apresentado por Antônio Flávio B. Moreira em Mesa redonda na UFMT (2012).

34 Dados os movimentos críticos de associações acadêmicas, como a Associação Nacional de Pósgraduação e Pesquisa em Educação (ANPEd), a Associação Brasileira de Currículo (ABdC) e a Associação Brasileira de Pesquisa em Ensino de Ciências (ABRAPEC). 
ensina às crianças e o que elas aprendem na escola" sob o risco de os teóricos de currículo serem ignorados pelos políticos reformadores de currículos (GALIAN e LOUZANO, 2014, p. 1116).

A adesão a ambas as teorias crítica e pós-crítica de currículo está, textualmente, expressa no Currículo em Movimento do Distrito Federal (2018) como opções teóricas fundantes, afora a Pedagogia Histórico-Crítica e a Psicologia Histórico Cultural, na concretização do projeto de educação e de sociedade que se almeja, haja vista essas perspectivas apresentarem

[...] o ato educativo como profundamente revolucionário, no sentido de provocar nas pessoas mudanças de vida a partir da apropriação do patrimônio cultural da humanidade. Nas interações, por meio do uso de instrumentos e signos, as pessoas se humanizam, são modificadas pela cultura e a modificam, numa relação dialética. [...] Portanto, as crianças atribuem sentido e atuam sobre o mundo, fazem história e cultura, em meio às relações humanas. Elas são seres de memória, que vivenciam seu presente e projetam seu futuro. São seres que possuem um corpo que expressa múltiplas linguagens. São seres que se constituem nas e pelas relações sociais e culturais existentes no mundo. Desse modo, as crianças, para além da filiação a um grupo etário próprio, são sujeitos ativos que pertencem a uma classe social, a um gênero, a uma etnia, a uma origem geográfica. (DISTRITO FEDERAL, 2018, p. 20 e 23).

O pluralismo teórico, "[...] como perspectiva epistemológica, é o uso consciente e reflexivo de conceitos, ideias de diferentes teorias, as quais são articuladas para compor um quadro teórico" (MAINARDES, 2018, p. 13), caracterizado como teorização combinada, que se diferencia da teorização adicionada a qual resulta na sobreposição de conceitos e ideias desarticulados e inconsistentes.

No caso do Distrito Federal, esse pluralismo, aparentemente, não indica mera justaposição de teorias ou ecletismo, é resultado de um processo histórico de debates, encontros, conferências que se iniciaram em 2010 entre os profissionais da educação de diferentes instâncias político-administrativas, inclusos os professores, que culminou na primeira versão em 2014 e foi mantido em 2018.

Essa tendência está presente em diversos documentos curriculares subnacionais que mesclam perspectivas, concepções, autores e definições ora de modo coerente ora incoerente para fundamentar as escolhas curriculares e pedagógicas. Ante esse movimento, problematizamos: quais são as consequências 
de um documento curricular anunciar que é crítico, pós-crítico ou híbrido para a formação continuada de professores, a organização do trabalho pedagógico e a didática em sala de aula? Essa questão é nodal para Lawrence Stenhouse (1975), referência nos estudos sobre o desenvolvimento profissional dos professores, bem como essencial para o desenvolvimento curricular. De onde as reformas curriculares deveriam partir: dos saberes da prática docente.

Tais aspectos ultrapassam os limites desta pesquisa, visto que o movimento da BNCC é oposto ao que propõe Stenhouse, e nos encontramos no início da fase de implementação dessa política. De qualquer modo, a busca por teorias expressa a dinâmica de apreensão da realidade e de concepções para enxergar o fenômeno. Por essa razão, necessitamos de variadas visões teórico-epistemológicas de mundo, de aprendizagem e de conhecimento. No caso em tela, as concepções de educação e de currículo estão pautadas nos princípios da Educação Integral, abordada na seção a seguir.

\subsection{Cenário Conceitual Nacional com o Advento da BNCC}

O compromisso com a Educação Integral está expresso na BNCC ao

[...] assumir uma visão plural, singular e integral do adolescente, do jovem e do adulto - considerando-os como sujeitos de aprendizagem - e promover uma educação voltada ao seu acolhimento, reconhecimento e desenvolvimento pleno, nas suas singularidades e diversidades. Além disso, a escola, como espaço de aprendizagem e de democracia inclusiva, deve se fortalecer na prática coercitiva de não discriminação, não preconceito e respeito às diferenças e diversidades. (BRASIL, 2016b, p. 12).

A tirar pelos vocábulos e expressões plural, singular, acolhimento, desenvolvimento pleno, diversidades, democracia inclusiva, coercitiva, não discriminação, não preconceito, respeito percebemos o quanto a escola é atravessada por inúmeras questões não exclusivamente pedagógicas e curriculares. É o lócus onde se materializam demandas cognitivas, afetivas, físicas, éticas, estéticas, de relacionamento interpessoal e de inserção social, que compõem a educação integral. 
Essa proposição remonta à Paideia grega de formação do corpo e do espírito do homem. No Brasil, o termo Educação Integral apareceu no Manifesto Integralista de 1932, fundamentada na tríade Deus, Pátria e Família, com "[...] um forte componente moralista, em que as verdades fundamentais do movimento são sempre trazidas à tona, consolidando uma visão reprodutora na relação educaçãoensino" (SIQUEIRA e COLARES, 2018, p. 194).

Essa visão é absorvida pelo Manifesto dos pioneiros da educação nova (1932) na tarefa de superação da escola tradicional com o intuito de preparar o indivíduo para uma sociedade em constante mutação a exigir mais que fixação de conteúdos, motivo pelo qual se foa em métodos e técnicas, bem como no produto sobre o processo de conhecimento.

Diante desse objetivo, surge a proposta de educação em tempo integral, denominada por Saviani de "hipertrofia horizontal e vertical da escola", que consiste tanto na ampliação do tempo quanto na antecipação do início da escolaridade. Essa tendência se concretiza na BNCCEl que contempla os bebês de zero ano, prenunciada por Saviani ao mencionar que "A própria família, em lugar de requerer para si a exclusividade da educação, na primeira infância, tende a exigir a educação escolar desde a mais tenra idade; se possível, desde o nascimento" (SAVIANI, 2013b, p. 84).

Desse modo, as políticas públicas educacionais se avolumam, servem de braços estatais e refletem um Estado metamórfico a exigir professores e escola também metamórficos, aptos a implementarem as múltiplas agendas governamentais. Nesse território desembocam os programas de combate à pobreza, ao uso de drogas, à gravidez precoce, campanhas ambientais, de vacinação, de educação no trânsito etc., e transitam agentes comunitários, agentes de saúde, conselheiros tutelares, amigos da escola, policiais.

Essas hipertrofias da escola tendem a secundarizá-la, "[...] esvaziando-a de sua função específica, que se liga à socialização do saber elaborado, convertendo-a numa agência de assistência social, destinada a atenuar as contradições da sociedade capitalista" (SAVIANI, 2013b, p. 85). No mesmo sentido, Young afirma que não "[...] cabe à escola resolver os problemas sociais, de forma alguma. Mas, se a escola for bem-sucedida em seu papel específico, alguns desses problemas podem diminuir". (GALIAN e LOUZANO, 2014, p. 14) 
O excerto do documento curricular referencial da Bahia (2019), intitulado "Saúde na Escola", exemplifica essa hipertrofia da escola e visa possibilitar "[...] a implementação de estratégias mais efetivas para o enfrentamento dos problemas de saúde mapeados no território e, principalmente, na proposição de soluções mais adequadas" (BAHIA, 2019, p. 82), como:

[...] prevenção das Infecções Sexualmente Transmissíveis (IST); prevenção e controle da Dengue/Chikingunya/Zika vírus e outras arboviroses: prevenção e controle ao uso do álcool, tabaco e outras drogas; promoção da cultura de paz e da valorização da vida; prevenção das violências e a promoção de hábitos e atitudes saudáveis; saúde sexual e saúde reprodutiva; prevenção de doenças imunopreveníveis, entre outras, contribuindo, assim, para a formação integral dos estudantes". (BAHIA, 2019, p, 83).

Enganam-se os professores acreditando que lecionarão apenas a disciplina de formação. Enganam-se os que creem ser o magistério dom, sacerdócio e vocação. O desafio é a escola rever e reafirmar suas especificidades e seu âmbito de atuação na função pública para o ofício nada trivial do magistério, que requer conhecimentos sobre desenvolvimento humano, Psicologia da Educação, didática, normas nacionais, locais e o Projeto Político- Pedagógico da unidade escolar, conforme Saviani (2013b, p. 84):

Em outros termos, a escola tem uma função especificamente educativa, propriamente pedagógica, ligada à questão do conhecimento; é preciso, pois, resgatar a importância da escola e reorganizar o trabalho educativo, levando em conta o problema do saber sistematizado, a partir do qual se define a especificidade da educação escolar.

Contudo, os movimentos recentes apontam para "[...] o ressurgimento dos princípios tradicionais e técnicos de ensino travestidos de uma suposta inovação tecnológica e teórica tornarem os rumos das políticas em currículo por diversos países" (SILVA F. 2018, p. 14).

Nesse cenário e no contexto do Movimento Global de Reforma da Educação [Global Education Reform Movement - GERM] ${ }^{35}$, Saviani (2010) lança mão dos prefixos "neo" e "pós" para categorizar as múltiplas vertentes pedagógicas

35 SAHLBERG, Pasi. Lições finlandesas 2.0: o que a mudança educacional na Finlândia pode ensinar ao mundo? São Paulo: SESI-SP editora, 2018. 
ressurgidas com o neoprodutivismo/pós-fordismo/pós-keynesianismo, quais sejam: neo-escolanovismo/pós-modernismo, neoconstrutivismo/pós-metanarrativas e neotecnicismo. Ressaltamos que o "neo" aqui não denota a acepção de inédito ou recente, mas a ideia de retorno, imitação, reforma, e o "pós" não remete a algo que evolui no sentido dialético do termo - realidade que se transforma, preservando aspectos relevantes anteriores e trazendo elementos novos propiciadores de avanço.

Com a naturalização das desigualdades sociais, a crise do capital e o desemprego estrutural mundial, o neoprodutivismo chega com a ideia de que a escola precisa preparar o sujeito para se tornar empregável, pois o pleno emprego preconizado pela economia keynesiana e pelo Estado do bem-estar social cederam lugar ao modelo toyotista, que busca por trabalhadores temporários para competirem diariamente por trabalho sem garantias trabalhistas. Esse fenômeno é atualmente conhecido como "uberização", em que o novo proletariado de serviços na era digital disputa o privilégio da servidão. Segundo Ricardo Antunes (2018), privilegiados são os que conseguem sobreviver e se manter "empregados", mesmo que em regime de servidão.

Segundo Saviani (2010), essa "pedagogia da exclusão" está, especialmente, presente na BNCC do Ensino Médio (BRASIL, 2017a) que promove o alijamento da formação dos jovens ao prever a obrigatoriedade de apenas língua portuguesa e matemática nos três anos do ensino médio, "retirando deles a possibilidade da apropriação do conhecimento, meio de sua humanização, e reforça a desigualdade característica da sociedade capitalista" (SILVA; PAULA, 2019, p. 6), e dissimulada nos vocábulos protagonismo, empreendedorismo, resiliência, processos criativos, resolução de problemas. Nessa lógica, o jovem da classe trabalhadora, "empresário de si", é agente e responsável por suas escolhas, como se as condições materiais mínimas fossem idênticas e garantidas para todos.

Esse nexo é igualmente revitalizado no neo-escolanovismo, no qual o desenvolvimento de "Competências", que é a "outra face da pedagogia do aprender a aprender" (SAVIANI, 2010, p. 437) constitui o pilar da Educação para o século XXI, difundido pelo Banco Mundial, pela OCDE e pelos reformadores empresariais da educação, inspiradores e coautores da BNCC.

Em Educar por Competências: o que há de novo? (2008) autores importantes do campo do currículo apresentam a entrada da abordagem em "Competências" no 
âmbito educacional a partir de um modelo europeu para o ensino superior, dada a origem desse enfoque na formação profissionalizante, expandida para os níveis básicos de ensino.

Autores importantes para os estudos curriculares discorrem sobre pontos cruciais que precisam ser considerados antes de se desenvolver currículos nacionais baseados em Competências, visto que os dissensos na adoção dessa perspectiva se dão desde suas finalidades. Para eles, existiriam três vertentes a destacar (SACRISTÁN et al., 2011, p. 8), a primeira defende a necessidade de preparar sujeitos eficientes e competitivos para atender às exigências de um mercado global; a segunda compreende que esse enfoque transformaria a educação em adestramento e consequente desumanização do indivíduo; e a terceira vislumbra uma oportunidade de superação de conteúdos antigos não funcionais apta a criar uma sociedade não apenas eficiente, mas justa, democrática e inclusiva. $O$ autor ressalta que:

O problema se apresenta quando esse modelo das competências pretende ser a solução dos desafios que o sistema educacional tem pela frente; quando pretende redimi-lo de suas carências, por não nos referirmos à importância que dizem que o modelo de competências tem para tornar as economias mais competitivas, para ajudar na obtenção da realização pessoal, e ao mesmo para uma sociedade mais integrada. (SACRISTÁN, 2011, p. 39).

Santomé (2011) retrata o caráter polissêmico da palavra "Competência" aplicada aos campos administrativo, jurídico, econômico; da sociolinguística com Noam Chomsky, da psicologia desenvolvimentista em Jean Piaget, da antropologia de Claude Lévi-Strauss, entre outros, e recobra que a origem do termo para o âmbito educacional liga-se à formação profissional. Esta advém do movimento empresarial de "eficiência social" taylorista, foi vitalizada por John F. Bobbit na década de 1970, nos Estados Unidos e fundamentada na Teoria do Capital Humano desenvolvida por Gary Becker.

Conforme o autor,

As filosofias que dão origem ao discurso das competências se apresentam como 0 resultado de debates técnicos e, por conseguinte, no qual devem participar exclusivamente pesquisadores de prestígio, personalidades especialistas pretensamente reconhecidas pelo mundo todo e, portanto, que suas decisões não 
possam ser postas em dúvida. Nesse tipo de proposta, pretende-se obter o consentimento dos professores e, em geral, da sociedade dizendo que aqui não há lugar para política, mas sim unicamente para o discurso técnico-científico. (SANTOMÉ, 2011, p. 169).

Essas são circunstâncias complexas para figurar como eixo estruturante de uma reforma, visto que os políticos reformadores da educação têm desconsiderado a cultura profissional do docente, promovido a atualização editorial de livros e materiais didáticos, que por sua vez, determinam a matriz referencial das avaliações e da formação docente em torno de um currículo mínimo centrado em competências cognitivas e socioemocionais, para o qual, urgem estudos e práticas pedagógicas na ação.

A ótica socioemocional se associa ao neoconstrutivismo, advinda da teoria psicológica genética de Piaget referente ao processo de construção da aprendizagem. Para Saviani (2010), a base teórica do construtivismo se metamorfoseou ao ser apropriada pelo campo da pedagogia, especialmente por formuladores de políticas educacionais, pedagogos e professores, reconfigurado no neoconstrutivismo. Segundo esse entendimento

[...] seu domínio delimitado pelo emprego de instrumentos perceptivos e motores, ela só trabalha sobre as realidades, os índices perceptivos e os sinais motores e não sobre os signos, os símbolos e os esquemas representativos ou os conceitos verdadeiros que implicam inclusão de classes e relações. (SAVIANI, 2010, p. 435).

Nessa "nova" roupagem construtivista, as competências e as habilidades práticas e socioemocionais são reivindicadas para que o indivíduo seja resiliente e se adapte em uma sociedade móvel, fluida e líquida. Daí a ênfase em técnicas e métodos para a aquisição de conhecimento pelo próprio indivíduo em oposição à transmissão-assimilação entre professores e alunos.

A teoria da psicologia do desenvolvimento humano que avança em relação ao desenvolvimento natural da criança é a Psicologia Histórico-Cultural de Vigotsky, ao "[...] romper o aprisionamento biológico da psicologia e passar para o campo da psicologia histórica humana" (VIGOTSKY, 2011, p. 863). Essa teoria não se atém apenas aos dados naturais da criança que condicionam a aprendizagem, mas também a como as funções naturais transformam todo o curso do pensamento natural ao entrar em contato com o plano sociocultural, pois o "[...] signo localizado 
fora do organismo, assim como o instrumento, está separado do indivíduo e consiste, em essência, num órgão da sociedade ou num meio social" (VIGOTSKY, 2011, p. 863).

De acordo com Duarte (2016) "[...] que a pedagogia que pode realizar de maneira mais coerente as mediações entre a psicologia histórico-cultural e a educação escolar na sociedade contemporânea é a pedagogia histórico-crítica" (DUARTE, 2016, p. 37) dado o contexto sociopolítico e ideológico de luta em que ambas as teorias surgiram.

A última vertente, o neotecnicismo, sustenta a "pedagogia corporativa", em que o Estado, permeável aos atores da iniciativa privada, absorve práticas do setor empresarial para a obtenção do máximo resultado com o mínimo de dispêndio. Inicialmente, o alvo estava voltado para a Educação Superior desde a década de 1990; agora, a mira se volta para a Educação Básica, pois 73,5\% dos estudantes frequentam escolas da rede pública de ensino (CAMPOS, 2017). Desse modo, já se opera o mecanismo dos vouchers, na creche e na educação infantil, que consiste no recebimento de "cheque-educação" pelos pais para escolherem a escola particular para os filhos.

No Ensino Médio, as escolas charters - escolas terceirizadas pelas organizações sociais sem fins lucrativos - tornam-se uma realidade iminente, na qual $20 \%$ da formação geral básica e dos itinerários formativos do ensino médio diurno e 30\% do noturno poderão ser cursados a distância (BRASIL, 2017a). Nas palavras de Freitas (2018a, p. 57), a "destruição do sistema público de educação é a agenda oculta da reforma empresarial", estruturada em torno da privatização, responsabilização, meritocracia e de testes padronizados em uma base comum, atrelados a soluções privatizantes para a escola.

Assim, as múltiplas versões pedagógicas: "pedagogia da exclusão", "pedagogia corporativa", "pedagogia da qualidade total" cunhadas por Saviani na obra História das ideias pedagógicas no Brasil em 2007, se assemelham às tendências didático-pedagógicas em curso no Brasil, fundamentadas nas pedagogias das competências em que "[...] o debate central é como os cidadãos devem ser formados e de que maneira utilizar as competências como referenciais ou indicadores para fazer as avaliações externas dos sistemas educacionais sobre uma base curricular comum" (SACRISTÁN et al., 2011, p. 9). 
Evidencia-se a importância atribuída às avaliações internacionais estandardizadas e censitárias de larga escala, que vêm sobredeterminando o par dialético objetivo/conteúdo (FREITAS, 2002), e redirecionando todo o trabalho pedagógico da escola e de sala de aula em torno dessa ideia. Nessa perspectiva, avaliar deixa de ser um ato de diagnóstico da aprendizagem para a correção de rumos e passa a atender às políticas de responsabilização e ranqueamento atreladas à liberação de verbas para a escola.

Essa corrente pedagógica teve origem na Escola Nova, nas interpretações do construtivismo de Piaget, sem, contudo, "[...] dar a importância que os construtivistas davam à ciência" (SAVIANI, 2016a) ${ }^{36}$. Ela foi recuperada no contexto político do neoliberalismo, durante a Conferência Mundial sobre Educação para Todos, em Jomtien, na qual aprovaram a Declaração Mundial sobre Educação para Todos ${ }^{37}$ (1990) e se consolidou com os quatro pilares das competências do aprender a aprender constantes do Relatório das Nações Unidas sobre a educação para o século XXI, conhecido como Relatório Jacques Delors (1999), duramente criticado por autores ligados às concepções críticas de educação e de currículo.

Para Saviani (2013a, p. 192), a Pedagogia do aprender a aprender objetiva dotar "[...] os indivíduos de comportamento flexíveis que lhes permitisse ajustar-se às condições de uma sociedade em que as próprias necessidades de sobrevivência não estão garantidas".

Na mesma direção, Duarte (2001, p. 36) assevera que "[...] as pedagogias do 'aprender a aprender' estabelecem uma hierarquia valorativa na qual aprender sozinho situa-se num nível mais elevado do que a aprendizagem resultante da transmissão de conhecimentos por alguém." No entanto, o autor enfatiza ser justamente pela transmissão de formas mais elevadas e desenvolvidas de conhecimentos, social e historicamente construídos, que se pode postular uma educação que fomente a autonomia intelectual de seus aprendizes.

Para Santomé (2011, p. 169), a intenção da escolha desse modelo para as políticas curriculares

36 Entrevista publicada pela Fundação Astrojildo Pereira, em 8 de fev. 2016. Disponível em: https://racismoambiental.net.br/2016/02/08/aprender-a-aprender-um-slogan-para-a-ignoranciaentrevista-com-demerval-saviani/ . Acesso em: 25 mar. 2018.

37 Ação conjunta entre o Banco Mundial (BM), o Fundo das Nações Unidas para a Infância (UNICEF), o Programa das Nações Unidas para o Desenvolvimento (PNUD) e a Organização das Nações Unidas para a Educação, a Ciência e a Cultura (UNESCO). 
"[...] foi e continua sendo a de preparar determinados setores da população, as classes sociais mais populares, para aprender determinados conhecimentos e habilidades que lhes permitem desempenhar com maior eficiência um trabalho profissional.

Nesse campo complexo em que os estudos das tendências pedagógicas e curriculares figuram, o teórico espanhol Sacristán (2000) organiza e classifica os currículos em seus processos de desenvolvimento, como: prescrito; apresentado aos professores; moldado pelos professores; em ação; realizado; e avaliado.

O currículo prescrito materializa a agenda educacional, demarca a organização política, normativa, administrativa e pedagógica para a educação, além de conteúdos e objetivos. Os Parâmetros Curriculares Nacionais (PCN) e as Diretrizes Curriculares Nacionais (DCN) desempenharam esse papel desde a década de 1990, função atual desempenhada pela BNCC e pelos currículos subnacionais.

O currículo apresentado ou elaborado aos professores, por sua vez, é, geralmente, preparado por diferentes instâncias que interpretam e apresentam o currículo prescrito aos professores por meio de orientações, guias, materiais, livros didáticos. O atual Programa Nacional do Livro e do Material Didático (PNLD) passou a incluir softwares e jogos educacionais, materiais destinados a reforço escolar, correção de fluxo, formação docente e gestão escolar.

O currículo moldado pelos professores constitui a reconfiguração das prescrições gerais às especificidades da escola e da sala de aula, quando há autonomia docente individual e/ou coletiva para isso, que pode ser exercida por meio do Projeto Político-Pedagógico da escola e dos projetos constantes dele, por exemplo.

Já o currículo em ação "[...] é o elemento no qual o currículo se transforma em método" (SACRISTÁN, 2000, p. 105) e se corporifica na prática do docente em sala de aula, na qualidade de reconfigurador curricular, por meio de recursos cognitivos e intelectivos advindos da formação e dos saberes da prática pedagógica, além dos recursos materiais. Nível em que os equívocos conceptuais da prescrição, em grande medida, refletem na ação. 
O currículo realizado remete aos efeitos social, cognitivo, cultural, pedagógico produzidos em consequência das práticas didático-pedagógicas que, efetivamente, afetam as práticas sociais e as aprendizagens de todos.

Por fim, o currículo avaliado é fruto de um processo de exame e validação da política educacional idealizada pelos atores estatais, feitores do currículo, para fins de diagnóstico e controle. As avaliações de larga escala, nacional e internacional, têm sido o meio de responsabilizar professores e alunos e de avaliar e hierarquizar o currículo.

Nota-se que, pela primeira vez na história curricular brasileira, todas essas fases de desenvolvimento do currículo foram cumpridas, induzidas pela política da BNCC, inclusive a do currículo avaliado. Em 2019, os estudantes do $2^{\circ}$ ano do Ensino Fundamental realizaram provas de Língua Portuguesa e Matemática, e os alunos do $9^{\circ}$ ano do Ensino Fundamental, as provas de Ciências da Natureza e Ciências Humanas, tendo por referência a Base Nacional Comum Curricular (BRASIL, 2019a).

Enfim, as opções teórico-epistemológicas e a organização curricular presentes nos currículos das UF confirmam o currículo como campo de disputa e tensões, identidade, poder, currere, desconstrução, reprodução, reificação em uma escola hipertrofiada por inúmeras demandas sociais.

A pluralidade de concepções e perspectivas parecem ser ora conscientes ora inconscientes, com predominância daquele modo, não obstante a assistência técnica de especialistas tanto na construção da BNCC quanto na atualização dos currículos subnacionais diante dessa norma central.

Conjunturas que nos incitam a ponderar se estaríamos caminhando para uma epistemologia curricular brasiliana ou se se trata apenas de uma retropia (BAUMAN, 2017), utopia de volta ao passado, para o problema da marginalidade na educação. 


\section{OS CURRÍCULOS SUBNACIONAIS À LUZ DA BNCC: O QUE OS DADOS REVELAM}

A emergência de adequação curricular ao núcleo comum impeliu os estados e o Distrito Federal a revisitarem os seus documentos e a incorporarem a norma nacional aos valores locais e culturais para a Educação Básica.

Nesse processo de reafirmação e autenticação de suas especificidades, o currículo é também uma linguagem por meio da qual os significados são produzidos e negociados, as diferenças marcadas e as identidades criadas. Conforme Woodward (2000):
A identidade, pois, não é o oposto da diferença: a identidade depende da diferença. Nas relações sociais, essas formas de diferença - a simbólica e a social - são estabelecidas, ao menos em parte, por meio de sistemas classificatórios. Um sistema classificatório aplica um princípio de diferença a uma população de uma forma tal que seja capaz de dividi-la (e a todas as suas características) em ao menos dois grupos opostos - nós/eles (WOODWARD, 2000, p. 39, grifos da autora).

Desse modo, os "documentos de identidade" (SILVA, 2002) perfilam os traços culturais e de poder que não se restringem ao dualismo do eu/outro, mas se fazem notar em inúmeros aspectos que vão desde a escolha do nome do documento às justificativas teórico-epistemológicas de afiliação, rejeição ou hibridismo em relação à Base. Os currículos subnacionais funcionam, assim, como um significante importante da diferença e da identidade associado a direito de aprendizagem, Educação Integral, autonomia docente e discente, projeto de vida etc.

Neste capítulo, trazemos as análises dos textos das propostas curriculares subnacionais à luz da BNCC, que nos permitem compreendê-las nos quesitos: i) Aspectos gerais - nome, adesão ao ProBNCC, número de páginas, datas de envio e aprovação, e abrangência; ii) Concepção de Educação e de Currículo - princípios, proposta pedagógica e organizador curricular; iii) Classificação - temas favoráveis a currículo, temas favoráveis a orientação; e iv) Grau de adesão à BNCC.

Primamos pelo conjunto de indícios que nos permitem inferir as tendências predominantes dos documentos curriculares, em um esforço para não incorrer em estereotipia ou análises rasas, dadas as dificuldades encontradas, especialmente, nas apropriações conceituais, léxicas e epistemológica que ora tendem ao ecletismo 
ora ao pluralismo teórico. Reconhecemos a complexidade do campo curricular, por isso o nosso cuidado em apresentar uma análise que consiga ir além da aparência descritiva a que os dados nos remetem.

\subsection{Aspectos Gerais}

O Quadro 17 sintetiza os aspectos gerais dos currículos subnacionais:

Quadro 17 - Aspectos gerais dos currículos subnacionais

\begin{tabular}{|c|c|c|c|c|c|c|}
\hline UF & NOME & ProBNCC & PÁGINAS & ENVIO & APROVAÇÃO ${ }^{\star *}$ & ABRANGÊNCIA \\
\hline$A C$ & $\begin{array}{l}\text { Currículo de referência } \\
\text { único do Acre }\end{array}$ & Sim & 1.714 & 07/12/2018 & 22/03/2019 & $22 / 22$ \\
\hline $\mathrm{AL}$ & $\begin{array}{c}\text { Referencial curricular de } \\
\text { Alagoas }\end{array}$ & Sim & 882 & $13 / 11 / 2018$ & $30 / 01 / 2019$ & $102 / 102$ \\
\hline AM & $\begin{array}{l}\text { Referencial curricular } \\
\text { amazonense }\end{array}$ & Sim & 1.496 & $05 / 11 / 2108$ & $16 / 04 / 2019$ & $62 / 62$ \\
\hline $\mathrm{AP}$ & $\begin{array}{l}\text { Referencial curricular } \\
\text { amapaense }\end{array}$ & Sim & 614 & 09/11/2018 & $19 / 12 / 2018$ & $16 / 16$ \\
\hline BA & $\begin{array}{l}\text { Documento curricular } \\
\text { referencial da Bahia }\end{array}$ & * & 475 & 15/7/2019 & 13/08/2019 & $417 / 417$ \\
\hline CE & $\begin{array}{l}\text { Documento curricular } \\
\text { referencial do Ceará }\end{array}$ & Sim & 931 & 04/12/2018 & 06/12/2018 & $184 / 184$ \\
\hline DF & $\begin{array}{c}\text { Currículo em Movimento } \\
\text { do Distrito Federal }\end{array}$ & Sim & 422 & 08/10/2018 & $04 / 12 / 2018$ & - \\
\hline ES & $\begin{array}{l}\text { Currículo do Espírito } \\
\text { Santo }\end{array}$ & Sim & 1.182 & $01 / 11 / 2018$ & 27/12/2018 & $78 / 78$ \\
\hline GO & $\begin{array}{c}\text { Documento curricular } \\
\text { para Goiás }\end{array}$ & * & 705 & $19 / 10 / 2018$ & 06/12/2018 & $246 / 246$ \\
\hline MA & $\begin{array}{c}\text { Documento curricular do } \\
\text { território maranhense }\end{array}$ & Sim & 482 & 24/12/2018 & 27/12/2018 & $217 / 217$ \\
\hline MG & $\begin{array}{l}\text { Currículo de referência } \\
\text { de Minas Gerais }\end{array}$ & Sim & 918 & $11 / 12 / 2018$ & $13 / 12 / 2018$ & $690 / 853$ \\
\hline MS & $\begin{array}{l}\text { Currículo de referência } \\
\text { de Mato Grosso do Sul }\end{array}$ & Sim & 821 & $30 / 11 / 2018$ & 06/12/2018 & $79 / 79$ \\
\hline MT & $\begin{array}{l}\text { Proposta Curricular do } \\
\text { estado de Mato Grosso }\end{array}$ & Sim & 668 & $21 / 11 / 2018$ & $28 / 11 / 2018$ & $141 / 141$ \\
\hline PA & $\begin{array}{c}\text { Documento Curricular do } \\
\text { estado do Pará }\end{array}$ & Sim & 361 & $8 / 11 / 2018$ & 20/12/2018 & $144 / 144$ \\
\hline PB & $\begin{array}{l}\text { Proposta Curricular do } \\
\text { estado da Paraíba }\end{array}$ & Sim & 635 & $29 / 11 / 2018$ & 07/12/2018 & $217 / 223$ \\
\hline $\mathrm{PE}$ & Currículo de Pernambuco & * & 746 & $11 / 11 / 2018$ & $20 / 12 / 2018$ & $185 / 185$ \\
\hline
\end{tabular}

Fonte: Elaborado pela autora (2020)

* Não mencionado textualmente

** Apêndice B 
Quadro 17 - Aspectos gerais dos currículos subnacionais (continuação)

\begin{tabular}{|c|c|c|c|c|c|c|}
\hline UF & NOME & ProBNCC & PÁGINAS & ENVIO & APROVAÇÃO** & ABRANGÊNCIA \\
\hline PI & $\begin{array}{c}\text { Currículo do Piaúi: um } \\
\text { marco para a educação } \\
\text { do nosso estado }\end{array}$ & $\operatorname{Sim}$ & 534 & $06 / 12 / 2018$ & $15 / 08 / 2019$ & $177 / 224$ \\
\hline PR & $\begin{array}{c}\text { Referencial curricular do } \\
\text { Paraná: Princípios, } \\
\text { Direitos e Orientações }\end{array}$ & $\operatorname{Sim}$ & 901 & 10 e 20/9/2018 & $22 / 11 / 2018$ & $382 / 399$ \\
\hline RJ & $\begin{array}{c}\text { Documento de orientação } \\
\text { curricular do estado do } \\
\text { Rio de Janeiro }\end{array}$ & $\operatorname{Sim}$ & 508 & Dez. 2018 & $08 / 11 / 2019$ & $92 / 92$ \\
\hline RN & $\begin{array}{c}\text { Documento curricular do } \\
\text { estado do Rio Grande do } \\
\text { Norte }\end{array}$ & $\operatorname{Sim}$ & 1.280 & $5 / 11 / 2018$ & $26 / 11 / 2018$ & $167 / 167$ \\
\hline RO & $\begin{array}{c}\text { Documento Curricular de } \\
\text { Rondônia }\end{array}$ & $\ldots$ & $\ldots$ & $\ldots$ & $19 / 12 / 2018$ & $\ldots$ \\
\hline RR & $\begin{array}{c}\text { Documento Curricular de } \\
\text { Roraima }\end{array}$ & $\operatorname{Sim}$ & 586 & $13 / 11 / 2108$ & $19 / 02 / 2019$ & $14 / 14$ \\
\hline RS & $\begin{array}{c}\text { Referencial Curricular } \\
\text { Gaúcho }\end{array}$ & $*$ & 1.521 & $26 / 09 / 2018$ & $12 / 12 / 2018$ & $497 / 497$ \\
\hline SC & $\begin{array}{c}\text { Currículo Base da } \\
\text { Educação Infantil e do } \\
\text { Ensino Fundamental do } \\
\text { Território Catarinense }\end{array}$ & $*$ & 476 & Jun. 2019 & $17 / 06 / 2019$ & $295 / 295$ \\
\hline SE & $\begin{array}{c}\text { Currículo de Sergipe: } \\
\text { integrar e construir }\end{array}$ & $\operatorname{Sim}$ & 666 & $12 / 11 / 2018$ & $29 / 11 / 2018$ & $75 / 75$ \\
\hline SP & Currículo paulista & $\operatorname{Sim}$ & 526 & $19 / 12 / 2018$ & $19 / 06 / 2019$ & $612 / 645$ \\
\hline TO & $\begin{array}{c}\text { Documento Curricular } \\
\text { Tocantins }\end{array}$ & $\operatorname{Sim}$ & 772 & $29 / 10 / 2018$ & $14 / 03 / 2019$ & $139 / 139$ \\
\hline
\end{tabular}

Fonte: Elaborado pela autora (2020)

* Não mencionado textualmente

** Apêndice B

- Títulos dos documentos

Os vocábulos aglutinados a currículo ou curricular, presente em todos os documentos, indicam, como o próprio nome deixa antever, os propósitos iniciais expressos em: referencial - Alagoas (AL), Amazonas (AM), Bahia (BA), Ceará (CE), Paraná (PR), Rio Grande do Sul (RS); referência - Acre (AC), Minas Gerais (MG), Mato Grosso do Sul (MS); proposta - Mato Grosso (MT), Paraíba (PB); orientação/ões - Rio de Janeiro (RJ), Paraná (PR); e documento - Bahia (BA), Ceará (CE), Goiás (GO), Maranhão (MA), Pará (PA), Rio de Janeiro (RJ), Rio Grande do Norte (RN), Rondônia (RO), Roraima (RR) e Tocantins (TO).

Os substantivos pátrios sintetizam os títulos dos currículos do Espírito Santo (ES), Pernambuco (PE) e de São Paulo (SP), já o do Piauí (PI) contém a afirmação "um marco para a educação do nosso estado", e o de Sergipe (SE) "integrar e construir". Por sua vez, o de Santa Catarina (SC) traz a palavra "Base" em seu 
sintagma, e o "Movimento" do Currículo do Distrito Federal (DF) alude a uma permanente "[...] revisitação para se manter atualizado diante das constantes mudanças sociais, bem como para se adequar às novas legislações e normatizações." (DISTRITO FEDERAL, 2018, p. 8).

O que parece ser simplesmente uma nomenclatura pode nos dizer sobre a tentativa de defender e afirmar as finalidades e as perspectivas das propostas curriculares, seja invocando a autoria docente e das unidades escolares via projetos político-pedagógicos e gestão democrática, seja autenticando uma política verticalizada e única às redes estaduais, distrital e municipais de ensino.

Essa marcação simbólica está presente também nas fotos, ilustrações, leiaute, customização e design das capas, contracapas e dos divisores de capítulos dos documentos, os quais, em virtude dos limites e objetivos desta pesquisa, não serão tratados aqui, mas podem ser acessados em: http://basenacionalcomum.mec.gov.br/index.php?option=com_content\&view= article\&layout=edit\&id=207.

- Datas de envio e aprovação dos currículos

As datas e os lapsos temporais entre o envio das propostas pelas Secretarias de Educação (SE) e a aprovação pelos Conselhos de Educação (CE) ${ }^{38}$ nos dizem dos debates e das disputas no "território contestado" (SILVA, 2002) em que o currículo figura. Por isso a necessidade das duas colunas para essas ações colegiadas: envio e aprovação.

O ano de 2018 foi dedicado à (re)elaboração ${ }^{39}$ dos currículos da El e do EF. Conforme o MEC, este é um "[...] processo de tradução da BNCC em um documento curricular local e contempla tanto as redes que farão a sua primeira elaboração curricular, quanto as redes que já possuem currículo e farão uma atualização alinhada a BNCC" (BRASIL, 2018a, p. 6). Esta "[...] é a primeira vez que

38 Convencionamos como Secretarias de Educação (SE) e Conselhos de Educação (CE) para contemplar as Secretarias de Educação (SEDUC) e a Secretaria de Educação do Distrito Federal (SEDF), bem como os Conselhos Estaduais de Educação (CEE) e o Conselho de Educação do Distrito Federal (CEDF).

39 Segundo os estudos do (CENPEC, 2015) em 2014, CE, PA, RS e RR não tinham ou não disponibilizaram suas propostas curriculares para a pesquisa. 
Pernambuco constrói um currículo para a Educação Infantil" (PERNAMBUCO, 2018, p. 11).

A maior parte das SE enviaram seus currículos aos CE em 2018. Atribuímos esse feito ao auxílio técnico e financeiro despendido pelo MEC, por meio do ProBNCC ${ }^{40}$, criado para apoiar as Secretarias Estadual e Distrital de Educação e as Secretarias Municipais de Educação (SME) no processo de atualização ou elaboração e implementação de seus currículos alinhados à BNCC.

Embora BA, GO, PE, RS e SC não expressem, textualmente, adesão ao ProBNCC, as propostas mencionam o regime de colaboração entre o MEC, 0 CONSED e a UNDIME, o que nos permite inferir que todas as UF contaram com os seguintes apoios:

1. Assistência financeira, via Plano de Ações Articuladas - PAR às Seduc, com vistas a assegurar: (i) a qualidade técnica na construção do documento curricular em regime de colaboração entre estados, Distrito Federal e municípios para toda a Educação Básica, e (ii) a implementação dos currículos elaborados à luz da BNCC;

2. Formação oferecida pelo MEC para equipes de currículo e gestão do Programa nos estados; e

3. Assistência técnica que contempla: (i) pagamento de bolsas de formação para os professores da equipe ProBNCC, via FNDE, (ii) contratação de analistas de gestão, (iii) equipe alocada no MEC para apoio na gestão nacional do Programa, (iv) material de apoio, e (v) plataforma digital para apoiar a (re)elaboração do currículo e as consultas públicas. (BRASIL, 2019b, p. 4).

Nesse processo conjunto entre equipe multidisciplinar de especialistas, gestores, articuladores, coordenadores e leitores críticos constam ações como o Dia "D" da BNCC41, encontros formativos, conferências on-line, bem como encontros "[...] com as escolas privadas, num movimento de negociação constante para garantir a qualidade e equidade na elaboração deste documento. [...] e com o Sindicato do Ensino Privado" (RIO GRANDE DO SUL, 2018, p. 14 e 18). Contudo, como já tratado anteriormente, os professores, estudantes, pais e a sociedade civil

40 O Programa foi criado em conjunto com as entidades: Ministério da Educação (MEC), Conselho Nacional de Secretários de Educação (Consed) e União Nacional dos Dirigentes Municipais de Educação (Undime), que formam o Comitê Nacional de Implementação da BNCC, com o apoio da Sociedade Civil (por meio de Organizações), e das representações institucionais dos Conselhos Nacionais, Estaduais e Municipais (Conselho Nacional de Educação - CNE, Fórum Nacional dos Conselhos Estaduais de Educação - FNCE e União Nacional dos Conselhos).

41 Ocorrida em 16 de março de 2018. 
participaram dessa etapa do desenvolvimento curricular por consulta pública e/ou por audiência pública, sem direito a voto, apenas como voz no processo.

Os lapsos de tempo entre o envio e a aprovação podem sinalizar os processos políticos de discussão e negociação nessas instâncias. Ressaltamos que o tempo histórico de 2018 demarca o último ano de uma legislatura política e economicamente conturbada e de eleições para os cargos no executivo e legislativo federal e estaduais, período comumente associado a fisiologismos e disputas políticas.

AP, CE, DF, ES, GO, MA, MG, MS, MT, PA, PB, PE, PR, RN, RO, RS e SE concluíram o ciclo - envio e aprovação - de (re)elaboração dos seus currículos ainda em 2018. O Currículo de referência de Minas Gerais (2018) e o Documento curricular referencial do Ceará (2018) levaram dois dias entre o envio e a aprovação, enquanto o Documento de orientação curricular do estado do Rio de Janeiro (2019b) gastou onze meses para completar esse ciclo. Neste estado, foi constituído o Grupo Gestor de Assessoramento ${ }^{42}$, que subsidiou o Conselho Estadual de Educação do Rio de Janeiro (CEE-RJ) com análises conjunturais e sugestões por área/etapa/modalidade de ensino acerca do documento curricular. Em decorrência dessa parceria surgiram as "Contribuições Críticas de Especialistas (2019)", as quais contribuíram na elaboração do Relatório Avaliativo do conselheiro relator, apreciado pelo Conselho Pleno em novembro de 2019. De modo que, 2018, 2019 e 2020 demarcam os processos de desenvolvimento do currículo "apresentado aos professores", "moldado pelos professores" e "em ação" (SACRISTÁN, 2000) para todo o país em relação à Educação Infantil e ao Ensino Fundamental.

- Número de páginas

As Secretarias de Educação estruturaram seus documentos curriculares em volumes únicos para a El e o EF (AC, AP, BA, CE, GO, MA, MG, MS, PA, PB, PI, $P R, R J, R R, S C, S E$ e SP); em volumes duplos, sendo um para a etapa da El e outro para o EF (AL, DF, PE e RN); em volumes triplos, divididos em El e, anos iniciais e anos finais do EF (AM e MT); divididos em seis cadernos (ES e RS) : El, Linguagens, Matemática, Ciências Humanas, Ciências da Natureza e Ensino

42 Composto pela Associação de Pós-graduação e Pesquisa em Educação - ANPED, Associação Brasileira de Currículo - AbdC, Associação Nacional de Política e Administração da Educação ANPAE, e pelo Fórum Estadual de Educação do Estado do Rio de Janeiro - FEERJ. 
Religioso; e, no caso de Tocantins, em quatro cadernos: El; Linguagens; Ciências Humanas e Ensino Religioso; Ciências da Natureza e Matemática. Além disso foi elaborado o "Guia de implementação do documento curricular do Tocantins" (TOCANTINS, 2019, p. 24), a fim de "orientar e esclarecer as responsabilidades de cada instância neste contexto de aprimoramento curricular do processo de ensino e aprendizagem" (TOCANTINS, 2019, p. 5).

O número de páginas constante do Quadro 17 refere-se ao total de laudas que compõem os volumes e os cadernos dos currículos, excluída a publicação complementar de Tocantins.

O Currículo de Referência Único do Acre (ACRE, 2019) chama a atenção por ser o mais analítico dos currículos, conter o maior número de páginas (1.714) e trazer reflexões sobre os componentes curriculares; conceitos-chave e abordagem metodológica; parte diversificada e especificidades do estado do Acre; orientações de aplicabilidade dos componentes; competências gerais da educação básica e de área; e o organizador curricular por ano para cada disciplina escolar do EF, além de temas transversais e integradores, propostas de atividades e atividades de avaliação etc. Além disso, ele conceitua direitos e objetivos de aprendizagem, conteúdos, competências e habilidades, criança e infância, bem como as seções "O que é importante considerar" e "Algumas implicações práticas sugeridas".

Já o Documento Curricular do Estado do Pará (2018) é o mais sintético de todos (361 páginas), não obstante contemple os aspectos essenciais em relação aos princípios educacionais, concepção de currículo, etapas e modalidades de ensino, eixos estruturantes, avaliação formativa, as cinco áreas de conhecimento para "[...] os diferentes grupos sociais e/ou comunidades sejam elas campesinas, ribeirinhas, quilombolas, indígenas ou citadinas" (PARÁ, 2018, p. 17). O Documento dispõe também sobre Educação Hospitalar e Educação para sujeitos privados de liberdade.

A relação entre o quantitativo de páginas e a margem de liberdade dedicada à autonomia docente se concretiza no "Currículo de Referência Único do Acre" (ACRE, 2019, grifo nosso), considerado por nós como o mais prescritivo dos documentos, na medida em que "[...]parametriza a elaboração das propostas pedagógicas e do projeto político pedagógico de todas as escolas das redes de ensino, na totalidade da região acreana" (ACRE, 2019, p. 4). Esta análise será ampliada às demais unidades da Federação na seção 3 deste capítulo. 
- Abrangência

Os documentos curriculares de MG, PB, PI, PR e SP não são extensivos a todas as redes estaduais e municipais. Diferentemente das demais UF, nas quais os currículos construídos em regime de colaboração referem-se ao território e não estão restritos às secretarias estaduais.

Em Minas Gerais, dos 853 municípios, cerca de 690 participaram dos "Encontros Municipais" (MINAS GERAIS, 2018, p. 8) para a redação do currículo deste estado. Não está claro, contudo, se os municípios ausentes nos encontros aderiram ou não ao subnacional de seus estados.

$\mathrm{Na}$ Paraíba, ocorreu a "[...] mobilização do Gestor Interlocutor dos 217 (duzentos e dezessete) municípios do pacto de implementação da BNCC e da Proposta Curricular do Estado da Paraíba" (PARAÍBA, 2018, p. 14), dentre os 223 existentes.

Por sua vez, o Currículo do Piauí: um marco para a educação do nosso estado (2019) traz uma lista nominal exaustiva, em apêndice, dos 177 dos 224 municípios que aderiram ao regime de colaboração, seus respectivos prefeitos e secretários municipais (PIAUÍ, 2019, p. 515).

Dezessete municípios paranaenses ${ }^{43}$ possuem sistemas próprios de ensino, e 382 fazem parte do sistema estadual. Resultado de um processo "[...] histórico de reflexão quanto à construção de currículos" (PARANÁ, 2018, p. 5), iniciado na década de 1980 com a elaboração do Currículo Básico do Estado do Paraná, reestruturado nos anos 90 para atender aos Parâmetros Curriculares Nacionais, e presente na construção coletiva, em 2003, de elaboração das Diretrizes Curriculares Orientadoras da Educação Básica para a Rede Estadual de Ensino do Paraná, publicada em 2008. Assim, o Referencial Curricular do Paraná: princípios, direitos e orientações à luz da BNCC, constitui referência para a construção dos 382 currículos municipais.

A ficha técnica do Currículo paulista (2019) arrola os coordenadores, articulador, analista de gestão, redatores das áreas de conhecimento e adiciona o trecho: "[..] e todos os 74.229 participantes do Estado e dos 612 Municípios Paulistas" (SÃO PAULO, 2019, p. 5) do total dos 645 existentes.

43 Araucária, Cascavel, Chopinzinho, Curitiba, Guarapuava, Ibiporã, Jacarezinho, Londrina, Palmas, Palmeira, Paranaguá, Pinhais, Ponta Grossa, São José dos Pinhais, Sarandi, Telêmaco Borba e Toledo (PARANÁ, 2018, p. 4). 
Esse trabalho conjunto alinha-se ao previsto na estratégia 7.1 do Plano Nacional de Educação (PNE) (BRASIL, 2014a), segundo o qual, a pactuação interfederativa seria a ferramenta para definir as diretrizes pedagógicas para a educação básica e a base nacional comum dos currículos, respeitando a diversidade regional, estadual e local.

\subsection{Concepção de Educação e de Currículo}

\section{- Princípios}

Os princípios explícitos da educação e do ensino que sustentam a BNCC e os currículos das UF resgatam os fundamentos de educação em relação ao desenvolvimento social expressos nos artigos 205 a 214 da Constituição Federal de 1988.

Esses fundamentos foram multiplicados na Lei de Diretrizes e Bases (LDB/1996); nos PCN 1997/1998/2000; na PNE 2001/2014 e nas mais de uma dezena de Diretrizes Curriculares Nacionais para: a Educação Básica; a Educação Infantil; o Ensino Fundamental de nove anos; o Ensino Médio; a Educação Especial; a Educação Escolar Indígena; a oferta de educação de jovens e adultos em situação de privação de liberdade; a Educação Escolar Quilombola; a Educação das Relações Étnicos-Raciais; o Ensino de História e Cultura Afro-Brasileira e Africana; a Educação Ambiental; as escolas do campo dentre outras.

Desses desdobram-se os princípios da laicidade da escola pública, os princípios norteadores da rotina e os pressupostos: (i) éticos (autonomia, responsabilidade, solidariedade, respeito ao bem comum, ao meio ambiente, e às diferentes culturas, identidades e singularidades); (ii) políticos (direitos de cidadania, exercício da criticidade, respeito à ordem democrática); e (iii) estéticos (sensibilidade, criatividade, ludicidade, liberdade de expressão nas diferentes manifestações artísticas e culturais), amplamente reproduzidos nas propostas curriculares. Ademais, são extraídas das diversas diretrizes curriculares nacionais e da Lei de Diretrizes e Bases (1996) premissas, objetivos e a organização das áreas, das competências e habilidades.

Quanto aos princípios implícitos, Burgos e Bellato (2019) denominaram-nos "pós-gerencialistas", tendo em vista que para: 
[...] reconectar a escola com a democracia pressupõe uma espécie de volta a princípios abandonados nesse percurso de mais de três décadas, quando se partiu em busca de um modelo administrativo capaz de conciliar tantas expectativas contraditórias em face do sistema escolar; uma volta aos fundamentos que, para boa parte desses autores, remete à tradição deweyana, que afinal tem a escola como uma instituição umbilicalmente vinculada à construção de uma sociedade democrática, que não pode se render às razões de um Estado tecnocrático e muito menos a uma ética mercantil que aposta na competição como vetor capaz de produzir eficiência e eficácia. Uma volta a velhos ideais, que fariam da escola uma das agências modernas mais importantes para a democracia, fonte de igualdade, autonomia, liberdade, solidariedade (fraternidade), cooperação e empatia. (BURGOS e BELLATO, 2019, p. 933).

Esse é um ideário materializado nas dez competências gerais da BNCC, em que resiliência, protagonismo, autonomia são palavras-chave, replicadas sistematicamente nos documentos curriculares das UF, de maneira que as comunidades educacional e escolar incorporem esses fundamentos nas práticas pedagógicas orientadas em torno de uma educação integral.

A profusão de regras e regulamentações permite-nos concordar com parte das comunidades científica e acadêmica que afirmam ser a Base prescindível, na medida em que já dispúnhamos de regulamentações fundamentais e suficientes para os currículos e a organização do trabalho pedagógico. Dito de outro modo, não era por falta de leis e princípios que a educação brasileira não estava a contento. Os esforços deveriam ser no sentido de implementar as estratégias com vistas ao alcance das metas vigentes do PNE (2014-2024), por exemplo, e de todas as diretrizes curriculares nacionais. A justificativa do MEC, ao dizer que as diretrizes são amplas e a BNCC contempla as essencialidades, não se aplica a tanta especificidade.

\section{- Proposta pedagógica}

Alguns documentos curriculares não expõem in verbis as bases teóricas que sustentam suas escolhas pedagógicas ou não se detêm em uma única concepção. O pluralismo de ideias e de concepções pedagógicas é legítimo, previsto no artigo 206, inciso III, da Constituição Federal de 1988 (BRASIL, 1988).

Cumpre-nos destacar, contudo, que existem termos muito específicos, tributários de sentidos e visões de mundo próprios das pedagogias críticas, a 
exemplo de "emancipação", "educação libertadora", "educação emancipadora" em Paulo Freire; e "conhecimento histórico, objetivo, científico", "saber sistematizado" impressos na Pedagogia Histórico-Crítica de Dermeval Saviani, para a qual "[...] educação é o ato de produzir, direta e intencionalmente, em cada indivíduo singular, a humanidade que é produzida histórica e coletivamente pelo conjunto dos homens" (SAVIANI, 2013b). O uso indiscriminado dessas expressões constitui inapropriação conceitual-terminológica em que se obsta "[...] o olhar em questões importantes, para se entreter apenas em escolhas de palavras, mais ou menos novas, com as quais se passa a sensação de que se está enfrentando os verdadeiros problemas da sociedade e, nesse caso, dos sistemas educacionais" (SACRISTÁN et al., 2011, p. 170).

Emancipação humana diz respeito à tomada de consciência, à ideia de superação da alienação marxiana e a não se adaptar "[...] às finalidades que thes sejam prescritas pelas minorias dominadoras (FREIRE, 2017, p. 88), visto que "[...] dominar aquilo que os dominantes dominam é condição de libertação" (SAVIANI, 2012, p. 67).

Posto isto, reafirmamos que os sentidos imbricados nesses termos não se coadunam com a Pedagogia das Competências ou com seu sinônimo Pedagogia do Aprender a Aprender, visto que, nesta perspectiva, "[...] torna-se cada vez mais inútil tentar conhecer tudo e, depois do ensino básico, a omnidisciplinaridade é um engodo" (DELORS, 1999, p. 91). Os visionários da educação para o século XXI apregoam a redução das disciplinas escolares e a construção dos próprios métodos de aquisição de competências e habilidades funcionais em oposição à aquisição de conhecimento científico, sistematizado e escolarizado.

Essa tecnocracia, segundo Santomé (2011, p. 170), "[...] utiliza todo um conjunto de conceitos pretendendo aparecer ao público como se o consenso em torno deles fosse total: 'competitividade', 'eficácia', 'produtividade', 'rendimento', 'racionalização', 'competência'”. Negligenciam, especialmente, os estudantes socialmente desfavorecidos, "[...] a finalidade mais fundamental da educação escolar, que é levar os alunos para além de sua experiência por formas às quais eles dificilmente teriam acesso em casa. Certamente é para isso que são as escolas" (YOUNG, 2011, p. 614).

Dessarte, procedemos à classificação das concepções pedagógicas em: <<HÍBRIDA >>; <<ECLÉTICA >>; ou << LITERAL >> a partir de expressões, conceitos 
e referenciais bibliográficos que nos subsidiaram nessa referenciação, não obstante as miscelâneas terminológicas encontradas.

O hibridismo caracteriza o Referencial Curricular amapaense que se " [...] baseia na Pedagogia Histórico-Crítica e na Psicologia Histórico-Cultural para a disciplina de Educação Física" (AMAPÁ, 2018, p. 175) e no "[...] desenvolvimento de competências e habilidades" (AMAPÁ, 2018, p. 18) para os demais componentes curriculares.

Essa conjugação teórica para Educação Física está presente no Referencial Curricular do Paraná (2018) e no Documento Curricular do Estado do Rio Grande do Norte (2018), sob as seguintes justificativas:

No Brasil, nas primeiras décadas do século XX, a Educação Física sofreu influências da filosofia positivista da área médica (higienista), dos militares (nacionalista) e dos pensamentos pedagógicos (escolanovistas da década de 1950), todas reforçando os exercícios físicos mecanizados, sem a preocupação em trabalhá-los de modo contextualizado nas escolas. (RIO GRANDE DO NORTE, 2018, p. 629).

As diversas abordagens pedagógicas da Educação Física no contexto escolar ganham relevância no final da década de 1970, quando:

De maneira geral, essa efervescência no campo das ideias não estabeleceu consenso para a área, entendida por estudiosos de variadas formas, ou seja, como área que trata da saúde, como área que lida como o movimento humano, como integrante exclusiva das ciências naturais/ciência da saúde, desconsiderando, conforme ressalta Daolio (2010), a clara interface com as ciências humanas. [...] Nesse sentido, a Educação Física passou (e continua passando) por uma "crise epistemológica", que se reflete nos currículos escolares. (PARANÁ, 2018, p. 337 e 338).

A Pedagogia Histórico-Crítica alicerça, do mesmo modo, a Educação Ambiental no Documento referencial da Bahia (2019), porque:

Nessa perspectiva, a Pedagogia Histórico-Crítica evidencia a consciência dos condicionantes histórico-sociais da educação (SAVIANI, 1985), respalda o trabalho com a Educação Ambiental, objetivando um equilíbrio entre teoria e prática, de forma a envolver os estudantes em aprendizagens significativas. Constitui-se como uma boa ferramenta para "despertar" as questões socioambientais, uma vez que requer dos profissionais da educação uma nova forma de trabalhar com os objetos e áreas do conhecimento de maneira 
contextualizada, evidenciando que os saberes advêm da história produzida pela humanidade e das diversas tecituras (sic) nas relações naturais e sociais (BAHIA, 2019, p. 87).

Reiteramos a legitimidade constitucional e teórica do pluralismo epistemológico, que, para nós, sinaliza avanços científicos na área $e$, consequentemente, ampliação dos espaços de debates e lutas no momento da modelagem curricular entre os atores envolvidos na atualização dos currículos.

Os excertos a seguir exemplificam o ecletismo conceptual entre a abordagem por Competências e a ideia de emancipação e acesso a conhecimentos históricos que constam dos documentos curriculares do MA, PI e RR:

\begin{abstract}
A estes princípios são associados a dois princípios pedagógicos, que fundamentam a BNCC, os quais estão contemplados nesta proposta curricular para o estado do Maranhão: 1. Foco nas competências para o alcance dos resultados esperados; Objetiva-se um currículo que seja expressão das relações sociais, na perspectiva da emancipação do indivíduo, e que não se reduza a um amontoado de conteúdos sem intencionalidade de construir uma formação humana e libertadora (MARANHÃO, 2018, p. 30 e 18, grifo nosso).
\end{abstract}

Emancipação e formação libertadora têm objetivos distintos do foco nas competências que se destina a "[...] valorizar o que é útil e imediato, ou seja, o conhecimento escolar é reduzido ao que é pragmático e ao que leva o indivíduo a se adaptar, e não a buscar mudanças em seu meio" (MALANCHEN, 2016, p. 24). Em outros trechos:

O currículo do Piauí apresenta ações que devem ser implementadas
no âmbito de cada instituição de ensino para que o desenvolvimento
das competências e habilidades propostas para os estudantes do
Piaúi se efetive; [...] tem como objetivo assegurar o direito aos
conhecimentos historicamente acumulados e, consequentemente, ao
desenvolvimento integral do estudante piauiense (PIAUÍ, 2019, p. 9 e
10, grifo nosso).

Conhecimentos historicamente acumulados são premissas que tomam "[...] a luta histórica pela emancipação do gênero humano como referência para postular que a escola trabalhe com conteúdos clássicos no campo científico, no artístico e no filosófico" (DUARTE, 2016, p. 110).

Os fragmentos do Documento curricular de Roraima (2019) expressam que: 
[...] faz-se necessário o desenvolvimento de competências e habilidades que Ihes possibilitem - aprender a conhecer, - aprender a fazer, - a viver juntos e - aprender a ser. Esses pilares da educação devem ser compreendidos como uma experiência global que deve permear toda a vida, tanto no aspecto cognitivo quanto no prático, para o sujeito enquanto pessoa e participante da sociedade. [...] as bases epistemológicas da EJA, enraizadas no pensamento freireano, compreendem o sujeito como elaborador e criador de conhecimentos. A ação educativa, portanto, está fortemente embasada no diálogo, promovendo a interação entre homem e mundo, onde professor e aluno atuam como educandos, pois, "ninguém ensina ninguém, os homens se educam uns com os outros", seguindo os princípios da justiça e da solidariedade, coerente com o propósito de emancipação das pessoas." (RORAIMA, 2019, p. 10 e 520).

A citação completa diz "Ninguém educa ninguém, ninguém educa a si mesmo, os homens se educam entre si, mediatizados pelo mundo". Para Freire (2017), a educação como prática da liberdade, ao contrário daquela que é prática da dominação, implica a negação do homem abstrato, isolado, solto, desligado do mundo, assim como a negação do mundo como uma realidade ausente dos homens. É imprescindível, portanto, que haja sujeitos como elaboradores e criadores de conhecimentos, em que se "[...] busca a emersão das consciências, de que resulte sua inserção crítica na realidade" (FREIRE, 2017, p. 98, grifos do autor).

Nesta pesquisa, a Pedagogia das Competências - grafada na BNCC como "Foco no desenvolvimento de competências"4" (BRASIL, 2016b, p. 11) - e a Pedagogia Histórico-Crítica são as duas grandes tendências pedagógicas que se antagonizam, entremeadas nos currículos subnacionais.

Em termos práticos, essa constatação, sem incorrer em emulações supérfluas, sinaliza, cada vez mais, a premência de estudos e pesquisas em teoria do conhecimento e teorias curriculares acerca da implementação dessa reforma educacional neoliberal travestida de discurso pseudo-emancipatório, visto que "[...] a educação precisa ser vista como um fim em si mesmo e não apenas como um meio para se atingir um fim (a posição instrumentalista)" (YOUNG, 2010, p. 66).

44 É esse também o enfoque adotado nas avaliações internacionais da Organização para a Cooperação e Desenvolvimento Econômico (OCDE), que coordena o Programa Internacional de Avaliação de Alunos (Pisa, na sigla em inglês), e da Organização das Nações Unidas para a Educação, a Ciência e a Cultura (Unesco, na sigla em inglês), que instituiu o Laboratório Latinoamericano de Avaliação da Qualidade da Educação para a América Latina (LLECE, na sigla em espanhol). 
O Quadro 21, Organizador Curricular, dispõe da classificação para todos os currículos dos estados e o Distrito Federal (Apêndice C).

\section{- Teoria curricular}

O campo curricular é simbioticamente articulado com a Pedagogia e dedicase, lato sensu, à organização do conhecimento, em que, para Moreira e Candau (2007, p. 19), "[...] as preocupações dos pesquisadores têm-se deslocado das relações entre currículo e conhecimento escolar para as relações entre currículo e cultura".

Essa tendência de um currículo multiculturalmente orientado, notadamente tipificado em eixos ou temas transversais e em eixos estruturantes/integradores, permeia as concepções curriculares teóricas tradicional, crítica e pós-crítica em busca de um currículo integrado (SANTOMÉ, 1998) e interdisciplinar.

$\mathrm{Na}$ vertente tradicional disciplinar, os eixos são transformados

[...] em matérias escolares ou o contrário, a transversalidade passa a ser encarada como uma ação pedagógica supérflua e inatingível, já que os conteúdos mínimos e essenciais, frutos de uma opção ideológica (APPLE, 2006) é que devem ser prioridade (SILVA F., 2020, p. 56).

Na perspectiva crítica, a organização curricular em torno das categorias do multiculturalismo - étnico-racial, de gênero, de orientação sexual, de classes sociais, de crença etc. - são tratadas transversalmente, ao passo que numa visão póscrítica, essas temáticas, preponderantemente, aparecem de modo estruturante/integrador.

No Brasil, esses prismas surgem nas normas legais e infralegais da década de 1990 e são mantidas na BNCC para que os sistemas e redes de ensino, e as escolas incorporem "[...] a abordagem de temas contemporâneos que afetam a vida humana em escala local, regional e global, preferencialmente de forma transversal e integradora" (BRASIL, 2016b, p. 17).

O Currículo de Referência de Mato Grosso do Sul (2018) apresenta três formas pelas quais os conhecimentos da Educação em Direitos Humanos podem ser inseridos no currículo: "[...] I- pela transversalidade e interdisciplinaridade; II- pelos conteúdos específicos de componentes curriculares já existentes; e III- pela 
combinação da transversalidade e da disciplinaridade" (MATO GROSSO DO SUL, 2018, p. 38).

Acerca da especificação dos eixos, Borges (2014) pondera que:

É preciso considerar que entre as condições de transversalidade curricular há o fato de que os conteúdos inseridos na categoria da transversalidade não têm caráter disciplinar, em geral figuram como acréscimo a algo anteriormente dado, ou seja, necessitam de trabalho conceitual prévio desenvolvido por estruturas disciplinares ou interdisciplinares. Localizar os temas transversais em campos curriculares disciplinares significa a interpretação equivocada do princípio básico que os constitui que é a confluência de diferentes objetos do conhecimento (BORGES, 2014, p. 1197, grifo da autora).

Na Modelagem Curricular do Documento Ceará (2018), interpretou-se que as dez competências gerais da BNCC foram estabelecidas para que pudessem ser desenvolvidas de modo transversal, visto que "[...] estas competências gerais integram-se à ação de cada componente curricular para articular a construção de conhecimentos, com o desenvolvimento de habilidades e a formação de atitudes e valores" (CEARÁ, 2018, p. 63, grifo do autor). Diferentemente do Documento curricular para Goiás (2018), no qual as "[...] competências gerais são o alicerce das competências específicas de área e de componentes; dos objetivos de aprendizagem e das habilidades" (GOIÁS, 2018, p. 43).

O Documento curricular referencial do Espírito Santo (2018) elenca doze temas integradores considerados na BNCC e acrescenta cinco novos temas que emergiram quando da elaboração do documento, são eles:

Direito da criança e do Adolescente; Educação para o Trânsito; Educação Ambiental; Educação Alimentar e Nutricional; Processo de Envelhecimento, Respeito e Valorização do Idoso; Educação em Direitos Humanos; Educação das Relações Étnico-Raciais e Ensino de História e Cultura Afro-Brasileira, Africana e Indígena; Saúde; Vida Familiar e Social; Educação para o Consumo; Educação Financeira e Fiscal; Trabalho, Ciência e Tecnologia; Diversidade Cultural. [...] Os novos temas integradores incluídos pelo Currículo do Espírito Santo são: Trabalho e Relações de Poder, Ética e Cidadania; Gênero, Sexualidade, Poder e Sociedade; Povos e Comunidades Tradicionais; Educação Patrimonial; Diálogo Intercultural e Inter-religioso. Propõe, ainda, a alteração dos temas Educação para o Consumo e Diversidade Cultural, já existentes na Base, para Educação para o Consumo Consciente e Diversidade Cultural, Religiosa e Étnica, respectivamente (ESPÍRITO SANTO, 2018, p. 32). 
Diante desse excesso temático, problematizamos se sobram tempo e espaço para as disciplinas tradicionais e os conteúdos objetivo de escolarização que constituem os componentes imprescindíveis para a interdisciplinaridade.

$\mathrm{Na}$ obra Currículo Integrado, eixo estruturante e interdisciplinaridade: uma proposta para a formação inicial de pedagogos, Silva F. (2020) apresenta um estudo contundente acerca dessa temática e aborda as principais características para a diferenciação dos eixos que fazem parte do Currículo Integrado:

a) Eixo Estruturante/Integrador [...]:

- Elemento norteador e nuclear da proposta curricular que costuma ser escolhido e debatido anteriormente às disciplinas.

- As disciplinas, temas, áreas e projetos gravitam em torno dele e o mesmo é quem promove o diálogo destas diferentes esferas do saber.

- Uma matéria escolar com os devidos critérios pode ser elevada ao nível de eixo estruturante.

É o eixo estruturante quem garante a verdadeira integração entre áreas do conhecimento e profissionais da educação Este eixo integrador tem a função de organizar as disciplinas e projetos e deixar espaço para a transversalidade, garantindo a construção efetiva de conhecimentos de alto nível para o perfil de saída dos estudantes que irão emancipar-se e interferir na realidade em que vivem.

b) Eixo ou Tema transversal:

- Mantém intensa ligação com o eixo estruturante.

- Garante caráter menos prescritivo e inflexível do currículo.

- Favorece o trabalho coletivo entre os profissionais da educação.

- Pode mudar periodicamente (mensalmente, bimestralmente, semestralmente).

- Garante a entrada de assuntos contemporâneos nas aulas, como: educação das relações étnico-raciais, sustentabilidade, misoginia, homofobia, xenofobia, drogas, tecnologias e redes sociais, sexualidade, etc.

- Pode romper com o etnocentrismo.

- Seu uso requer planejamento coletivo e sistemático.

As aulas que os envolve devem ter significado para docentes e discentes (SILVA F., 2020, p. 58).

Os variados arranjos curriculares, descritos no Quadro 21 - Organizador curricular (Apêndice $\mathrm{C}$ ), expõem as múltiplas formas de reconstrução e autenticação locais para a Educação Infantil (EI) e o Ensino Fundamental (EF), as 
intencionalidades e visões de mundo que se deseja perpetuar, problematizar ou ocultar, independentemente da teoria curricular a que se afiliam ou desconsideram.

A totalidade das propostas curriculares para a Educação Infantil aderiu à organização curricular dos campos de experiência, estruturados em objetivos de aprendizagem e desenvolvimento. Da outra forma para o Ensino Fundamental, identificamos variações designativas para campos de atuação, tais quais: unidades temáticas, eixos ou subeixos; para habilidades: objetos de conhecimento, objetivos de aprendizagem, competências específicas, temas integradores, conteúdos e alguns desdobramentos locais fundamentados no desenvolvimento das competências gerais da Base.

Do mesmo modo, na BNCC, a maioria dos documentos das UF não estão, textualmente, fundamentados em alguma teoria de currículo, com exceção do DF, MA, PB (para o componente Arte), RN e RS. Esse aspecto compromete a dinâmica de apreensão da realidade e de construção do conhecimento, para a qual as teorias são formuladas e a prática é colocada em ação como critério de validação daquelas.

\subsection{Adesão à BNCC}

Conformamos nosso entendimento de que a BNCC é currículo sim, no mínimo em nível prescrito (SACRISTÁN, 2000), pois os códigos pedagógicos são transferidos via mínimo comum e refletem na Organização do Trabalho Pedagógico (OTP), avaliação, formação docente e no material didático. Resta às secretarias de educação e redes de ensino configurá-lo em currículo apresentado aos professores (SACRISTÁN, 2000) e, aos professores, moldá-lo na ação, a fim de amenizar a atual verticalização.

A política curricular da Base definiu competências/habilidades para os conteúdos escolares, materiais didáticos, avaliações e formação docente instituída na Base Nacional Comum para a Formação Inicial de Professores da Educação Básica (BNC-Formação) ${ }^{45}$; ou seja, este currículo prescrito incide em todos os mecanismos que determinam a prática escolar, ainda que se declare como ponto de partida para os currículos subnacionais.

45 Resolução CNE/CP no 2/2019 (BRASIL, 2019c). 
Designamos os sinais <<MAIS >>; ou $<<M E N O S>>$ para qualificar os sentidos "próximos" ou "distantes" dos temas favoráveis à prescrição aludido à noção de um currículo enquanto produto, algo a ser seguido, estruturado em resultados pretendidos e hiper centrado no protagonismo do aluno; e dos temas favoráveis à orientação, os quais remetem a um processo de construção coletiva do currículo diante das especificidades locais, fortalecido pela autonomia docente, pela gestão democrática e pelo projeto político-pedagógico da unidade escolar.

O Quadro 18 sistematiza essas unidades de significação em uma aproximação aos indícios retirados dos currículos para a Educação Infantil e o Ensino Fundamental. 
QUADRO 18 - Temas favoráveis à prescrição/orientação

\begin{tabular}{|c|c|c|c|}
\hline 0 & TEMAS FAVORÁVEIS À PRESCRIÇÃO & TEMAS FAVORÁVEIS À ORIENTAÇÃO & $\begin{array}{l}\text { GRAU DE } \\
\text { ADESÃO }\end{array}$ \\
\hline \multirow[b]{2}{*}{$A C$} & $<<$ MAIS $>>$ & $<<$ MENOS $>>$ & \multirow[b]{2}{*}{ ALTO } \\
\hline & $\begin{array}{l}\text { "O Currículo de referência único do Acre [...] parametriza a elaboração } \\
\text { das propostas pedagógicas e do projeto político pedagógico de todas as } \\
\text { escolas das redes de ensino, na totalidade da região acreana." (p. 4). }\end{array}$ & $\begin{array}{c}\text { O currículo do Acre traz conceitos-chave, abordagem metodológica, } \\
\text { especificidades do estado, orientações, aplicabilidade, competências gerais, } \\
\text { referências para todas as disciplinas. }\end{array}$ & \\
\hline \multirow[b]{2}{*}{$A L$} & $<<$ MENOS $>>$ & $<$ MAIS $>>$ & \multirow[b]{2}{*}{ BAIXO } \\
\hline & $\begin{array}{l}\text { "Dentro desse contexto, os processos de ensino e aprendizagem } \\
\text { perpassam pelas Diretrizes Nacionais para a Educação Básica, pela } \\
\text { BNCC [...], pelo Referencial Curricular de Alagoas, pelo Projeto Político } \\
\text { Pedagógico da escola e pelo Plano de Aula do professor" (p. 35). }\end{array}$ & $\begin{array}{l}\text { "A partir deste referencial, a escola precisará reformular o seu Projeto } \\
\text { Político Pedagógico, enquanto documento, autônomo, vivo, adequado ao } \\
\text { seu alunado e às características do local, onde a escola se encontra, mas } \\
\text { sempre buscando diálogo com o global, garantindo as melhores } \\
\text { oportunidades possíveis de desenvolvimento para os educandos. (p. 62). }\end{array}$ & \\
\hline \multirow[b]{2}{*}{ AM } & $<<$ MAIS $>>$ & $<<$ MAIS $>>$ & \multirow[b]{2}{*}{ MÉDIO } \\
\hline & $\begin{array}{c}\text { "[...] a Comissão ProBNCC disponibiliza o Referencial Curricular } \\
\text { Amazonense com o intuito de atender aos interesses educacionais e à } \\
\text { necessidade de uma escolarização padronizada do } \\
\text { conhecimento a ser ensinado, ou seja, que as exigências dos conteúdos } \\
\text { sejam as mesmas em todas as redes de ensino." (p. 20). }\end{array}$ & $\begin{array}{c}\text { "O RCA [Referencial Curricular Amazonense] não é o fim, e em nenhum } \\
\text { momento deverá ser visto como um trabalho conclusivo, mas sim o início de } \\
\text { um processo direcionado. Isto é, trata-se de um documento como o } \\
\text { propósito de servir de norte, de subsídio para novas ações articuladas à } \\
\text { construção dos currículos, propostas pedagógicas, projetos político- } \\
\text { pedagógicos e políticas de formação continuada das redes de ensino } \\
\text { Estadual, Municipais e escolas privadas, levando em conta suas } \\
\text { especificidades locais." (p. 20) }\end{array}$ & \\
\hline \multirow[b]{2}{*}{ AP } & $<<$ MENOS $>>$ & $<<$ MAIS $>>$ & \multirow[b]{2}{*}{ BAIXO } \\
\hline & $\begin{array}{l}\text { "[...] o que será destacado aqui são os fundamentos e princípios } \\
\text { pedagógicos da BNCC, os quais a escola precisará considerar para a } \\
\text { (re)definição de sua filosofia/tendência pedagógica." (p. 18) }\end{array}$ & $\begin{array}{c}\text { "Na escola é a partir da construção do Projeto Político Pedagógico (PPP) e } \\
\text { na elaboração dos planos de aula que essa ação se inicia, pois será nas } \\
\text { aulas que a proposta da BNCC e os ideais da escola se materializam e a } \\
\text { partir daí são introduzidos socialmente com a vivência e protagonismo dos } \\
\text { estudantes." (p. 18) }\end{array}$ & \\
\hline \multirow[b]{2}{*}{ BA } & $<<$ MENOS $>>$ & $<<$ MAIS $>>$ & \multirow[b]{2}{*}{ BAIXO } \\
\hline & $\begin{array}{l}\text { "O DCRB [Documento Curricular Referencial da Bahia] tem como base as } \\
\text { orientações normativas da BNCC, complementada à luz das diversidades } \\
\text { e das singularidades do território baiano, de modo a colaborar com a } \\
\text { (re)escrita dos Projetos Políticos- Pedagógicos das Unidades Escolares. } \\
\text { (p. 14). }\end{array}$ & $\begin{array}{c}\text { "Trata-se de um documento aberto, não prescritivo, que pretende incorporar } \\
\text { inovações e atualizações pedagógicas advindas dos marcos legais, do } \\
\text { arcabouço teórico-metodológico do currículo, no processo de } \\
\text { implementação, considerando, também, aspectos identificados pelos } \\
\text { segmentos da comunidade escolar." (p. 13). }\end{array}$ & \\
\hline
\end{tabular}

Fonte: Elaborado pela autora (2019). 
QUADRO 18 - Temas favoráveis à prescrição/orientação (continuação)

\begin{tabular}{|c|c|c|c|}
\hline 0 & TEMAS FAVORÁVEIS À PRESCRIÇÃO & TEMAS FAVORÁVEIS À ORIENTAÇÃO & $\begin{array}{l}\text { GRAU DE } \\
\text { ADESÃO }\end{array}$ \\
\hline \multirow[b]{2}{*}{ CE } & $<<$ MAIS $>>$ & $<<$ MAIS $>>$ & \multirow[b]{2}{*}{ MÉDIO } \\
\hline & $\begin{array}{l}\text { "Então, mediante a clareza de que a BNCC tem papel indutor, no sentido, } \\
\text { sobretudo, de assegurar o direito a um aprendizado de qualidade para } \\
\text { todos, é lógico concluir que cabe aos estados seguir nesta mesma } \\
\text { direção, sempre construindo cenários que fortaleçam o município como } \\
\text { participante de processos formativos da inteligência municipal." (p. 28). }\end{array}$ & $\begin{array}{l}\text { "O presente documento [...] orienta no sentido de que a instituição escolar, } \\
\text { efetiva executora do currículo decorrente, sinta-se mobilizada e apoiada a } \\
\text { fazer acontecer com sucesso a ação curricular que ela própria, em ação } \\
\text { coletiva e a partir destes referenciais, tenha delineado." (p. 29). }\end{array}$ & \\
\hline \multirow[b]{2}{*}{ DF } & $<<$ MENOS $>>$ & $<$ MAIS $>>$ & \multirow[b]{2}{*}{ BAIXO } \\
\hline & $\begin{array}{c}\text { O currículo em Movimento do DF se propõe a "[...] ser permanentemente } \\
\text { avaliado e significado a partir de concepções e práticas empreendidas por } \\
\text { cada um e cada uma no contexto concreto das escolas e das salas de } \\
\text { aula desta rede pública de ensino" (p. 7) }\end{array}$ & $\begin{array}{c}\text { "Desta forma, propõe-se uma organização curricular progressiva, } \\
\text { valorizando a autonomia do professor e da escola para o planejamento do } \\
\text { trabalho pedagógico, de acordo os princípios epistemológicos de um } \\
\text { Currículo Integrado que preconiza a definição de objetivos e conteúdos } \\
\text { contextuais, flexíveis, interdisciplinares e que evidenciam a } \\
\text { indissociabilidade entre teoria e prática." (p. 110). }\end{array}$ & \\
\hline \multirow[b]{2}{*}{ ES } & $<<$ MENOS $>>$ & $<$ MAIS $>>$ & \multirow[b]{2}{*}{ BAIXO } \\
\hline & $\begin{array}{c}\text { "O currículo é compreendido como trajetória, viagem, percurso, } \\
\text { documento de identidade, potencializador das relações entre a nossa vida } \\
\text { e a do outro. São vidas em encontro num documento que propõe o } \\
\text { acolhimento e o respeito às identidades para as infâncias, adolescências, } \\
\text { juventudes e adultos capixabas com objetivo de garantir o direito à } \\
\text { educação integral." (p. 14). }\end{array}$ & $\begin{array}{c}\text { Por isso, trata-se de um referencial a ser usado como ponto de partida para } \\
\text { elaboração dos documentos orientadores institucionais, construindo de } \\
\text { forma coletiva e colaborativa, com os sujeitos e em cada contexto escolar, o } \\
\text { detalhamento e os modos de viabilizar práticas alinhadas as suas } \\
\text { concepções, indicações de avaliação e perspectivas metodológicas que } \\
\text { propõe (p. 18). }\end{array}$ & \\
\hline \multirow[b]{2}{*}{ GO } & $<<$ MAIS $>>$ & $<<$ MAIS $>>$ & \multirow[b]{2}{*}{ MÉDIO } \\
\hline & $\begin{array}{l}\text { "[...]o Documento Curricular para Goiás de acordo com a BNCC, visa dar } \\
\text { referência, sistematização e organização de unidades temáticas, objetos } \\
\text { de conhecimentos e habilidades alinhadas às competências gerais, de } \\
\text { área e específicas, na busca da formação integral do sujeito." (p. 535). }\end{array}$ & $\begin{array}{l}\text { Em vista disso, o diálogo entre professores generalistas-pedagogos (Anos } \\
\text { Iniciais), com os especialistas-licenciados (Anos Finais), e os especialistas } \\
\text { entre si, é pré-requisito para construção de uma proposta curricular que } \\
\text { garanta as aprendizagens e o desenvolvimento dos estudantes ao longo do } \\
\text { Ensino Fundamental, sendo o Projeto Político Pedagógico (PPP) o eixo } \\
\text { norteador e orientador de todo esse processo. (p. 205). }\end{array}$ & \\
\hline \multirow[b]{2}{*}{ MA } & $<<$ MENOS $>>$ & $<<$ MAIS $>>$ & \multirow[b]{2}{*}{ BAIXO } \\
\hline & $\begin{array}{c}\text { "O currículo, numa relação dialética, é mais que a soma das partes: } \\
\text { planejamento + conteúdos + aulas + livros + atividades + interação } \\
\text { professor/estudante. É uma escola funcionando. Desde a recepção dos } \\
\text { estudantes na portaria até a sirene do último horário, tudo que acontece } \\
\text { ali é currículo, pois sempre se aprende, em todos os espaços na inter- } \\
\text { relação humana." (p. 17). }\end{array}$ & $\begin{array}{c}\text { Tal postura é requerida para que, em nome da autonomia pedagógica, o } \\
\text { professor não se desvincule da proposta pedagógica definida para a rede } \\
\text { em que a escola está inserida ou, até mesmo, que não se afaste da } \\
\text { proposta pedagógica que, coletivamente, foi definida para a comunidade } \\
\text { escolar e que aqui denominaremos unidade pedagógica, em que serão } \\
\text { pautadas as práticas curriculares. (p. 29). }\end{array}$ & \\
\hline
\end{tabular}

Fonte: Elaborado pela autora (2019). 
QUADRO 18 - Temas favoráveis à prescrição/orientação (continuação)

\begin{tabular}{|c|c|c|c|}
\hline 0 & TEMAS FAVORÁVEIS À PRESCRIÇÃO & TEMAS FAVORÁVEIS À ORIENTAÇÃO & $\begin{array}{l}\text { GRAU DE } \\
\text { ADESÃO }\end{array}$ \\
\hline \multirow[b]{2}{*}{ MG } & $<<$ MENOS $>>$ & $<<$ MAIS $>>$ & \multirow[b]{2}{*}{ BAIXO } \\
\hline & $\begin{array}{c}\text { "A proposta curricular [...] não pretende homogeneizar as práticas } \\
\text { docentes, mas sugerir caminhos que possibilitem a promoção da } \\
\text { autonomia de cada professor no desenvolvimento de seu trabalho." (p. } \\
\text { 738). }\end{array}$ & $\begin{array}{c}\text { "E há 'muitas Minas Gerais', ou seja, há grande diversidade regional e local } \\
\text { e o Projeto Pedagógico deve expressar e respeitar essa realidade." (p. } \\
\text { 878). "Assim, iremos trabalhar aqui com a concepção de currículo como } \\
\text { processo e não como produto, como comumente se compreende. Currículo } \\
\text { é experiência vivida e como tal envolve não só o levantamento dos } \\
\text { conteúdos a serem "ensinados", mas também práticas, atitudes, formas de } \\
\text { organização do trabalho." (p. 17). }\end{array}$ & \\
\hline \multirow[b]{2}{*}{ MS } & $<<$ MAIS $>>$ & $<$ MAIS $>>$ & \multirow[b]{2}{*}{ MÉDIO } \\
\hline & $\begin{array}{l}\text { "Assim, ao considerar crianças, adolescentes e jovens como agentes de } \\
\text { seu aprendizado, abre-se a oportunidade para que eles se empoderem } \\
\text { como cidadãos, como autores e construtores de conhecimentos." (p. 21). }\end{array}$ & $\begin{array}{c}\text { "Salienta-se que o Currículo de Referência de Mato Grosso do Sul é } \\
\text { instrumento basilar para a Secretaria de Estado de Educação, as } \\
\text { Secretarias Municipais de Educação e as Instituições Privadas de Ensino } \\
\text { elaborarem orientações curriculares e auxiliarem nos processos de revisão } \\
\text { dos projetos pedagógicos das escolas a partir de suas próprias } \\
\text { necessidades, sempre em regime de colaboração, com orientações aos } \\
\text { envolvidos na gestão administrativa, formativa e pedagógica de todo o } \\
\text { processo educativo." (p. 23). }\end{array}$ & \\
\hline \multirow[b]{2}{*}{ MT } & $<<$ MAIS $>>$ & $<<$ MAIS $>>$ & \multirow[b]{2}{*}{ MÉDIO } \\
\hline & $\begin{array}{l}\text { "Em face a essas questões, considerando a diversidade de recursos } \\
\text { semióticos e tecnológicos presentes no cotidiano atual, no que tange o } \\
\text { trabalho pedagógico em sala de aula, é importante organizar o currículo } \\
\text { em espiral, atentos à complexidade das habilidades/competências a } \\
\text { serem construídas pelos estudantes em interface com ano de } \\
\text { escolaridade." (p. 37). }\end{array}$ & $\begin{array}{c}\text { "Os professores não são simples executores do currículo, ao contrário, são } \\
\text { mediadores, intérpretes, autores e construtores do currículo em ação } \\
\text { (SACRISTÁN, 2000) [...]" (p. 128). }\end{array}$ & \\
\hline \multirow[b]{2}{*}{ PA } & $<<$ MENOS $>>$ & $<<$ MAIS $>>$ & \multirow[b]{2}{*}{ BAIXO } \\
\hline & $\begin{array}{c}\text { "Vale ressaltar que todas as reflexões aqui feitas devem estar em } \\
\text { consonância com a proposta pedagógica curricular da instituição } \\
\text { enquanto projeto pedagógico maior que rege e dá direção às intervenções } \\
\text { estabelecidas sem deixar de problematizar em sua constituição a } \\
\text { complexa relação histórica, política, social, econômica e cultural das } \\
\text { relações humanas imbricadas." (p. 63). }\end{array}$ & $\begin{array}{c}\text { "[...] o currículo deve assumir nova postura frente à diversidade cultural, } \\
\text { cabendo ao professor a elaboração de suas atividades em sala de aula } \\
\text { levar em conta essas diferenças." (p. 17). }\end{array}$ & \\
\hline
\end{tabular}

Fonte: Elaborado pela autora (2019). 
QUADRO 18 - Temas favoráveis à prescrição/orientação (continuação)

\begin{tabular}{|c|c|c|c|}
\hline 0 & TEMAS FAVORÁVEIS À PRESCRIÇÃO & TEMAS FAVORÁVEIS À ORIENTAÇÃO & $\begin{array}{l}\text { GRAU DE } \\
\text { ADESÃO }\end{array}$ \\
\hline & $<<M E N O S>>$ & $<<$ MAIS $>>$ & \\
\hline PB & $\begin{array}{c}\text { "Constitui-se, dessa maneira, como um documento norteador para a } \\
\text { elaboração das propostas curriculares no âmbito dos municípios e para } \\
\text { construção dos projetos pedagógicos das escolas no estado da Paraíba, } \\
\text { configurando-se como ponto de partida, aberto e flexível, para se pensar } \\
\text { as necessidades de aprendizagem dos diversos sujeitos que compõem a } \\
\text { sociedade paraibana." (p. 15). }\end{array}$ & $\begin{array}{c}\text { "[...] o professor poderá, partindo do conteúdo comum, ampliá-lo com base } \\
\text { nas necessidades específicas de sua própria comunidade escolar, sem } \\
\text { prejuízo daquilo que é preconizado - como direito - para todos os } \\
\text { estudantes do Brasil. Se necessário, o docente poderá também substituir } \\
\text { alguns conteúdos propostos que forem julgados muito distantes da } \\
\text { realidade social e material do seu alunado por outros mais condizentes com } \\
\text { a realidade de sua Escola." (p. 181). }\end{array}$ & BAIXO \\
\hline \multirow[b]{2}{*}{ PE } & $<<$ MAIS $>>$ & $<<$ MENOS $>>$ & \multirow[b]{2}{*}{ ALTO } \\
\hline & $\begin{array}{c}\text { "Nesse contexto, é necessário que os professores se apropriem desses } \\
\text { pressupostos e planejem suas práticas pela abordagem de competências, } \\
\text { desconstruam conceitos que ainda estão cristalizados nos modelos } \\
\text { tradicionais que fragmentam os conhecimentos nos diversos } \\
\text { componentes curriculares [...]" (p. 24). }\end{array}$ & $\begin{array}{c}\text { "Nesse sentido, um currículo pautado na formação integral considera o } \\
\text { estudante como centro do processo pedagógico e compreende que todas } \\
\text { as ações voltadas para as aprendizagens devem ser construídas, avaliadas } \\
\text { e reorientadas a partir dos contextos, interesses e necessidades dos } \\
\text { estudantes, [...]" (p. 21). }\end{array}$ & \\
\hline \multirow[b]{2}{*}{$\mathrm{PI}$} & $<<$ MENOS $>>$ & $<<$ MAIS $>>$ & \multirow[b]{2}{*}{ BAIXO } \\
\hline & $\begin{array}{l}\text { "[...] o currículo precisa ser algo vivo, e não um documento estático. Para } \\
\text { tanto, requer efetividade nos processos de desenvolvimento das } \\
\text { experiências de aprendizagem, que garantam o exercício do dever dos } \\
\text { trabalhadores da educação e os direitos dos estudantes." (p. 9). }\end{array}$ & $\begin{array}{l}\text { "É salutar lembrar que, assim como a construção dos currículos dos } \\
\text { municípios foi coletiva, a Proposta Pedagógica e o Regimento Interno das } \\
\text { escolas, deverão contar com a participação de todos os atores que fazem a } \\
\text { comunidade escolar, para que os mesmos possam sentir-se partícipes do } \\
\text { processo e naturalmente encontrar significado na sua missão de educar." } \\
\text { (p. 10). }\end{array}$ & \\
\hline \multirow[b]{2}{*}{ PR } & $<<$ MENOS $>>$ & $<<$ MAIS $>>$ & \multirow[b]{2}{*}{ BAIXO } \\
\hline & $\begin{array}{l}\text { "Partindo da organização do tempo e espaços disponíveis, cabe à escola } \\
\text { repensar democraticamente e propor alternativas metodológicas, } \\
\text { valorizando as experiências de professores e estudantes, que promovam } \\
\text { a contextualização e a interdisciplinaridade, rompendo com a rigidez e } \\
\text { fragmentação historicamente constituídas." (p. 27). }\end{array}$ & $\begin{array}{l}\text { "É importante destacar o papel das escolas e do trabalho de toda a } \\
\text { comunidade escolar que, na reflexão sobre o seu projeto político- } \\
\text { pedagógico, sobre os diferentes componentes curriculares e no diálogo com } \\
\text { a realidade social de cada comunidade afirmaram a perspectiva } \\
\text { multicultural, pluriétnica e crítica das desigualdades e mazelas sociais." (p. } \\
18 \text { ). }\end{array}$ & \\
\hline
\end{tabular}

Fonte: Elaborado pela autora (2019). 
QUADRO 18 - Temas favoráveis à prescrição/orientação (continuação)

\begin{tabular}{|c|c|c|c|}
\hline 0 & TEMAS FAVORÁVEIS À PRESCRIÇÃO & TEMAS FAVORÁVEIS À ORIENTAÇÃO & $\begin{array}{l}\text { GRAU DE } \\
\text { ADESÃO }\end{array}$ \\
\hline \multirow[b]{2}{*}{ RJ } & $<<$ MENOS $>>$ & $<<$ MAIS $>>$ & \multirow[b]{2}{*}{ BAIXO } \\
\hline & $\begin{array}{l}\text { "De acordo com a Deliberação, o DOC-RJ deve agir como indutor das } \\
\text { revisões dos currículos escolares, bem como dos projetos político- } \\
\text { pedagógicos, não se colocando como um currículo geral, algo que não é } \\
\text { desejado pela sociedade civil e a própria BNCC não recomenda." (p. 12). }\end{array}$ & $\begin{array}{c}\text { "Não temos a pretensão de criar nenhum roteiro didático para execução de } \\
\text { atividades para cumprimento do(a) professor(a) no seu fazer pedagógico } \\
\text { com as crianças, muito pelo contrário, pretendemos fazer com que exerça } \\
\text { seu poder de autoria na escolha de práticas a serem promovidas com/e } \\
\text { para as crianças, através de sua formação profissional e continuada, assim } \\
\text { como a proposta pedagógica construída coletivamente nos espaços } \\
\text { escolares." (p. 35). }\end{array}$ & \\
\hline \multirow[b]{2}{*}{$\mathrm{RN}$} & $<<$ MENOS $>>$ & $<<$ MAIS $>>$ & \multirow[b]{2}{*}{ BAIXO } \\
\hline & $\begin{array}{c}\text { "Ensejamos, assim, um currículo que ofereça referências teórico- } \\
\text { metodológicas capazes de subsidiar o desenvolvimento das competências } \\
\text { e habilidades previstas na BNCC e que, ao mesmo tempo, dialoguem } \\
\text { intimamente com as práticas escolares cotidianas, com os contextos } \\
\text { regionais/locais e, especialmente, com as características e demandas dos } \\
\text { estudantes nas diferentes etapas e modalidades da Educação Básica."(p. } \\
16) \text {. }\end{array}$ & $\begin{array}{c}\text { "[...] possa se desdobrar nas propostas pedagógicas das unidades } \\
\text { escolares, nos planos de aula e, principalmente, no dia a dia dos espaços } \\
\text { educativos da escola e das salas de aula." (p. 16). }\end{array}$ & \\
\hline RO & ------- & ------ & \\
\hline \multirow[b]{2}{*}{$\mathrm{RR}$} & $<<$ MAIS $>>$ & $<<$ MAIS $>>$ & \multirow[b]{2}{*}{ MÉDIO } \\
\hline & $\begin{array}{l}\text { "Em primeira instância, é preciso reafirmar a cada instante que a BNCC } \\
\text { não tem como vocação prescrever, tão pouco reformar os currículos, ela } \\
\text { vem para apontar caminhos, propostas curriculares a serem construídas } \\
\text { por cada escola, considerando os direitos de aprendizagem que cada } \\
\text { aluno brasileiro tem, tornando-se um documento de referência para a } \\
\text { educação escolar, o que envolve as áreas de conhecimento, os } \\
\text { componentes curriculares, mas também um movimento inevitável de } \\
\text { reconfiguração das práticas de ensino, dos valores e da própria vida } \\
\text { escolar, nos modos de lidar com a complexidade que lhe é inerente." (p. } \\
15) \text {. }\end{array}$ & $\begin{array}{l}\text { "[...] elaboração cuidadosa, de um projeto político-pedagógico que propicie } \\
\text { experiências voltadas ao desenvolvimento dos diferentes tipos de } \\
\text { habilidades humanas e a formação continuada dos professores, que deve } \\
\text { ser ampliada, para um trabalho pedagógico focado no alcance dos objetivos } \\
\text { de aprendizagens e desenvolvimento de habilidades." (p. 12). }\end{array}$ & \\
\hline
\end{tabular}

Fonte: Elaborado pela autora (2019). 
QUADRO 18 - Temas favoráveis à prescrição/orientação (continuação)

\begin{tabular}{|c|c|c|c|}
\hline 0 & TEMAS FAVORÁVEIS À PRESCRIÇÃO & TEMAS FAVORÁVEIS À ORIENTAÇÃO & $\begin{array}{l}\text { GRAU DE } \\
\text { ADESÃO }\end{array}$ \\
\hline & $<<$ MAIS $>>$ & $<<$ MAIS $>>$ & \\
\hline RS & $\begin{array}{c}\text { "A educação escolarizada pensada para este documento está pautada no } \\
\text { direito de aprender [...] com foco no desenvolvimento de competências e } \\
\text { habilidades de cada etapa de ensino, vinculando as macrocompetências } \\
\text { da BNCC; e o entendimento do estudante como protagonista do processo } \\
\text { educativo" (p. 23). }\end{array}$ & $\begin{array}{c}\text { "Este é um documento balizador para construção dos currículos nas } \\
\text { escolas de diferentes esferas no Estado do Rio Grande do Sul. Cabe aos } \\
\text { sistemas e redes de ensino, bem como às escolas privadas, a construção } \\
\text { de Documento Orientador, viabilizando as peculiaridades locais no que } \\
\text { tange às questões curriculares." (p. 19). }\end{array}$ & MÉDIO \\
\hline \multirow[b]{2}{*}{ SC } & $<<$ MAIS $>>$ & $<<$ MENOS $>>$ & \multirow[b]{2}{*}{ ALTO } \\
\hline & $\begin{array}{l}\text { "O objetivo é manter a unidade de um documento, que entrelace seus } \\
\text { conceitos e dialogue com as matrizes norteadoras em todas as fases do } \\
\text { percurso formativo." (p. 8). }\end{array}$ & $\begin{array}{c}\text { "[...] a autonomia das diferentes redes de ensino na construção de matrizes } \\
\text { curriculares" para a implantação da EJA. (p. 70). }\end{array}$ & \\
\hline \multirow[b]{2}{*}{ SE } & $<<$ MAIS $>>$ & $<<$ MAIS $>>$ & \multirow[b]{2}{*}{ MÉDIO } \\
\hline & $\begin{array}{l}\text { "Importante ressaltar que a reconstrução curricular, para Sergipe, pautada } \\
\text { à luz da BNCC, impactará numa mudança de paradigma, em que o foco } \\
\text { será a formação integral do estudante por meio de competências a serem } \\
\text { desenvolvidas, considerando-o como sujeito de aprendizagem." (p. 125). }\end{array}$ & $\begin{array}{c}\text { "O currículo sergipano [...] não pretende homogeneizar e nem engessar o } \\
\text { trabalho docente, ao contrário, tem como objetivo principal apontar } \\
\text { caminhos que possibilitem a promoção da autonomia de cada professor no } \\
\text { desenvolvimento de seu trabalho e garantir a equidade de oportunidades } \\
\text { para todos os educandos." (p. 489). }\end{array}$ & \\
\hline \multirow[b]{2}{*}{ SP } & $<<$ MAIS $>>$ & $<$ MAIS $>>$ & \multirow[b]{2}{*}{ MÉDIO } \\
\hline & $\begin{array}{c}\text { "O Currículo Paulista define e explicita, a todos os profissionais da } \\
\text { educação que atuam no Estado, as competências e as habilidades } \\
\text { essenciais para o desenvolvimento cognitivo, social e emocional dos } \\
\text { estudantes paulistas e considera sempre sua formação integral na } \\
\text { perspectiva do desenvolvimento humano." (p. 11). }\end{array}$ & $\begin{array}{c}\text { "Esperamos que essas definições orientem a (re)elaboração da Proposta } \\
\text { Pedagógica de cada escola do território estadual, de maneira a que se } \\
\text { promova, em cada uma delas, a necessária organização dos tempos e dos } \\
\text { espaços, bem como práticas pedagógicas e de gestão compatíveis com as } \\
\text { aprendizagens essenciais que se pretende garantir a todos os estudantes." } \\
\text { (p. 11). }\end{array}$ & \\
\hline \multirow[b]{2}{*}{ TO } & $<<$ MENOS $>>$ & $<$ MAIS $>>$ & \multirow[b]{2}{*}{ BAIXO } \\
\hline & $\begin{array}{l}\text { "Espera-se que este referencial, que foi construído colaborativamente, a } \\
\text { partir da BNCC, seja visto de forma positiva e flexível, pois cada contexto } \\
\text { é único e o professor é essencial para que este Documento Curricular } \\
\text { seja efetivado em todo Estado do Tocantins." (p. 222). }\end{array}$ & $\begin{array}{c}\text { "A unidade pode desenvolver o seu Projeto institucional conforme as } \\
\text { características culturais da comunidade, pontos de interesses e } \\
\text { necessidades educativas. É importante que as crianças e professores } \\
\text { tenham espaço para dialogar com a proposta que necessita ser flexível à } \\
\text { mudança." (p. 39). }\end{array}$ & \\
\hline
\end{tabular}

Fonte: da autora (2020) 
Estimamos os graus ALTO, BAIXO e MÉDIO a partir da valoração <<MAIS>> ou <<MENOS>> concedidas aos "Temas favoráveis à prescrição" e "Temas favoráveis à orientação", sendo:

- $\quad$ <MAIS $>>$ prescrição e <<MENOS $>>$ orientação = ALTO grau de adesão à Base;

- $\quad<$ MENOS $>>$ prescrição e $<<M A I S>>$ orientação = BAIXO grau de adesão à Base; e

- <<MAIS >> prescrição e <<MAIS>> orientação = MÉDIO grau de adesão à Base.

O Quadro 19 (Grau de adesão à BNCC) sistematiza essa classificação:

\section{Quadro 19 - Grau de adesão à BNCC}

\begin{tabular}{|c|c|c|c|}
\hline UF & Temas favoráveis à prescrição & Temas favoráveis à orientação & Grau de adesão \\
\hline$A C$ & MAIS & MENOS & ALTO \\
\hline $\mathrm{AL}$ & MENOS & MAIS & BAIXO \\
\hline AM & MAIS & MAIS & MÉDIO \\
\hline $\mathrm{AP}$ & MENOS & MAIS & BAIXO \\
\hline $\mathrm{BA}$ & MENOS & MAIS & BAIXO \\
\hline CE & MAIS & MAIS & MÉDIO \\
\hline DF & MENOS & MAIS & BAIXO \\
\hline ES & MENOS & MAIS & BAIXO \\
\hline GO & MAIS & MAIS & MÉDIO \\
\hline MA & MENOS & MAIS & BAIXO \\
\hline MG & MENOS & MAIS & BAIXO \\
\hline MS & MAIS & MAIS & MÉDIO \\
\hline MT & MAIS & MAIS & MÉDIO \\
\hline PA & MENOS & MAIS & BAIXO \\
\hline PB & MENOS & MAIS & BAIXO \\
\hline $\mathrm{PE}$ & MAIS & MENOS & ALTO \\
\hline $\mathrm{PI}$ & MENOS & MAIS & BAIXO \\
\hline PR & MENOS & MAIS & BAIXO \\
\hline RJ & MENOS & MAIS & BAIXO \\
\hline $\mathrm{RN}$ & MENOS & MAIS & BAIXO \\
\hline RO & $\ldots \ldots$ & $\ldots \ldots$. & $\ldots \ldots$ \\
\hline $\mathrm{RR}$ & MAIS & MAIS & MÉDIO \\
\hline RS & MAIS & MAIS & MÉDIO \\
\hline SC & MAIS & MENOS & ALTO \\
\hline SE & MAIS & MAIS & MÉDIO \\
\hline $\mathrm{SP}$ & MAIS & MAIS & MÉDIO \\
\hline TO & MENOS & MAIS & BAIXO \\
\hline
\end{tabular}

Fonte: Elaborado pela autora (2020). 
A profusão conceptual e os equívocos teórico-epistemológicos da Base ecoam nos currículos subnacionais, ao menos no nível prescrito, e constituem aspectos adversos a essa análise que se pretende não reducionista. Consideramos os textos em particular de cada UF em comparação aos contextos gerais dos documentos para estimar os graus revelados pelas análises.

Em termos percentuais, $51 \%$ das propostas $(n=14)$ apresentam baixo grau de adesão à Base, pois assimilaram a norma central como orientação ao não fixarem as mesmas premissas teóricas, o mesmo modo de organização curricular em habilidades/competências e ao reforçarem a gestão e a autoria docente da escola via Projeto Político-Pedagógico. Outros 33\% foram estimados com o grau médio $(n=9)$ por creditarem uma parte de sua organização curricular ao comum nacional, e outra parte às especificidades das unidades escolares fortalecidas nos institutos de gestão democrática. Trazemos as incidências, "baixo" e "médio", como possíveis evidências da abundância normativo-prescritiva nacionais para a Educação Básica que a BNCC representa não obstante o ProBNCC. Por último, 11\% dos currículos subnacionais $(n=3)$ apresentam alto grau de adesão à política curricular de padronização que se assemelha a controle e inspeção. 


\section{CONSIDERAÇÕES FINAIS}

A reforma educacional em curso no Brasil, induzida e liderada pela Base Nacional Comum Curricular e viabilizada pela abertura política a práticas neoliberais dos governos Collor, FHC, Lula, Dilma e Temer, carrega o selo de ter sido construída por especialistas de conglomerados empresariais, corporações financeiras e organizações não governamentais, cognominados reformadores empresariais da educação.

Longe de representar uma revolução na educação brasileira, conforme discutimos ao longo desta pesquisa, essa política requenta agendas antigas da OCDE, UNICEF e do Banco Mundial para países periféricos, alicerçada no neoconstrutivismo da Pedagogia das Competências e do "Aprender a Aprender", sob a couraça do direito à educação e das exigências do século XXI, centralizada nas avaliações censitárias de larga escala.

Nossas palavras conclusivas não constituem uma epístola ou um escrito de uma entusiasta contrária à $\mathrm{BNCC}$, pelo contrário, trata-se de sentidos dialógicos que a unidade teoria/prática nos permite. Afinal, a Base já existe. Resta-nos alimentar o debate com esperanças fruto da consCiência e buscar por saídas "de baixo para cima", bottom-up, pois que as professoras somos currículo.

Esta dissertação está aplicada ao grupo de pesquisa "Currículo e processo formativo" (FE/UnB) na qual empregamos os elementos da teoria crítica de currículo, e está estruturada nos eixos: políticas públicas educacionais e curriculares; e teorias e concepções de educação e de currículo, sobre os quais propusemos analisar a forma pela qual as unidades da Federação atualizaram seus currículos à luz da BNCC.

Constituem objetivos específicos desta dissertação, discutir a premência de uma Base Nacional Comum Curricular; averiguar se as UF absorveram a BNCC como prescrição ou como orientação; identificar os pressupostos teóricoepistemológicos que sustentam as propostas curriculares subnacionais; e estimar o grau de adesão dos currículos à BNCC.

Esses prismas foram observados pelas lentes da Sociologia Política da Ação Pública e das teorias críticas de educação e de currículo, por meio das quais examinamos as pressuposições iniciais de que grande parte das unidades da Federação absorveram as prescrições da BNCC em seus documentos quanto aos 
fundamentos teórico-pedagógicos, às concepções de educação e à forma de organização curricular.

Recobrando a primeira pergunta de pesquisa acerca da imprescindibilidade de uma Base Nacional Comum Curricular, comprovaram-se neste estudo as marcas das mais de uma dezena de Diretrizes Curriculares Nacionais vigentes recorrentemente referenciadas nos currículos das unidades da Federação, das quais são reivindicados seus princípios, pressupostos, objetivos e conteúdos. As bases já estavam embutidas nas diretrizes para a Educação Infantil e o Ensino Fundamental.

Trata-se, portanto, de um excesso regulamentar, visto que o sistema educacional dispõe de diversas diretrizes expedidas pelo MEC por meio do CNE, de orientações pedagógicas das redes de ensino e de instrumentos de construção coletiva, como o Projeto Político-Pedagógico, no qual se pode imprimir o DNA de cada unidade escolar. Esses institutos são amplamente evocados nos textos dos currículos subnacionais. Em outros termos, a Base é uma abundância normativa.

Para além do sobejo, ao que tudo indica, a BNCC está cumprindo seu projeto oculto de terceirização da educação básica pública, inicialmente previsto para a educação infantil por meio de vouchers e para o ensino médio a distância via itinerários formativos. No entanto e em virtude da pandemia da COVID-1946, potencialmente, este propósito vem se alastrando para toda a educação básica. $O$ ensino a distância e o homeschooling estão justificados, potencializados pela crise epidemiológica de 2020. Porém, uma vez mais, os burocratas da educação se deparam com o fosso socioeconômico nacional do alunado. Lucram os que se empenham na manutenção do status quo, perdem os alunos das classes menos favorecidas e os professores, expostos à precarização e à exploração do trabalho remoto sem formação e recursos adequados.

Em face disso, entendemos que iniciar uma reforma educacional pelo currículo "de cima para baixo", top-down, do central para o local, denota dispêndio de tempo, energia, recursos intelectuais e financeiros ${ }^{47}$-- afora os encargos advindos com consultorias, editoração e formação docente -, os quais dificilmente corrigirão as disparidades de base material e de infraestrutura para o exercício da

\footnotetext{
46 Encontramo-nos em isolamento social por conta do novo coronavírus.

47 O Anexo D contém a resposta do MEC ao meu pedido de informação sobre os custos da BNCC aos cofres públicos.
} 
função primeira da escola, que é transmitir os conhecimentos científicos convertidos em saber sistematizado escolar.

Retomando a segunda pergunta de pesquisa, referente aos fundamentos teóricos que sustentam as escolhas pedagógicas e curriculares dos documentos, constatamos um pluralismo epistemológico nos currículos das UF caracterizando, por um lado, um hibridismo teórico, no qual, legitimamente, se articulam conceitos, resultado de avanços científicos de área para determinadas disciplinas e de prováveis escolhas fruto de disputas políticas que garantiram certos teóricos nas propostas curriculares. E, por outro lado, caracteriza um ecletismo conceitual reproduzido da Base em torno do desenvolvimento de competências cognitivas e socioemocionais conectado, inapropriadamente, a sentidos de emancipação, educação libertadora, conhecimento histórico, objetivo e científico, e saber sistematizado.

Essa é uma miscelânea epistemológica cujos efeitos para a formação docente, a organização do trabalho pedagógico e a didática em sala de aula ultrapassam os limites desta pesquisa que se propôs a analisar as prescrições da política curricular, não isentas de serem problematizadas.

Tais temas nos remetem à habilitação em nível médio para o exercício do magistério, mantida na atual reforma, agravada com a subversão do notório saber para a educação básica (artigos 61 e 62 da LDB/96, alterada pela Lei oo 13.415/2017) e com a instituição da Base Nacional Comum para a Formação Inicial de Professores da Educação Básica (BNC-Formação). Essas questões suscitam futuras investigações relativas ao desenvolvimento dessa política curricular que incide em todos os mecanismos da prática escolar: conteúdos, material didático, avaliações, formação docente, não obstante o bordão "a Base não é currículo".

Ressaltamos que os entusiastas da proposta lograram êxito em incutir a unidade habilidade/competência nas narrativas do magistério para as etapas e modalidades da educação básica, como se o tecnicismo embutido nessa ideia fosse efetivamente capaz de promover uma educação humanizada, equânime e de qualidade para todos.

É desolador ver o atual esforço do MEC, em recentes cursos on-line sobre a $\mathrm{BNCC}^{48}$, para definir e quantificar o valor das "competências" a partir de um exemplo

48 Disponível em https://youtu.be/JdFgXCQAebc. Acessado em 22 abr.2020. 
do que fazer para se deslocar em uma cidade, "consultar um mapa, pesquisar na internet o transporte mais rápido, decidir se vale a pena ir de táxi, ônibus, ou usar um aplicativo de transporte. [...] Percebeu quantas habilidades você usou? Lembrese, competência mobiliza habilidades" (BRASIL, 2020, n.p).

Assim, estão invisibilizadas as realidades sociais, culturais e locais da população que não tem conhecimentos para consultar mapas ou pesquisar na internet, tampouco recursos para escolher deslocar-se de táxi, ônibus ou "Uber". Sobrou competência/habilidade do corpo técnico do MEC na autenticação dessa concepção utilitária e rasa de educação. Será mesmo que são esses os saberes que os burocratas do currículo desejam para os jovens brasileiros, inclusive para seus próprios descendentes?

Em relação à teoria de currículo que alicerça a Base, os especialistas não se posicionaram textualmente. Tal silenciamento reverbera nos documentos subnacionais, confirmando que os equívocos teórico-epistemológicos do currículo prescrito chegam ao avaliado (SACRISTÁN, 2000).

$\mathrm{Na}$ educação infantil, os organizadores curriculares da totalidade das UF estão alinhados às prescrições dos campos de experiência e dos objetivos de aprendizagem e desenvolvimento; enquanto que, para o ensino fundamental, há algumas variações para campos de atuação, habilidades/competências fundamentados no desenvolvimento das competências gerais da Base.

A ausência de adesão a uma teoria de currículo da Base, se repete na maioria dos documentos das UF, com exceção do DF, MA, PB (para o componente Arte), RN e RS. São lacunas pelas quais resvalam nas visões de mundo, sujeito e conhecimento que se intenta perpetuar para a educação básica, e confirmam a premência de estudos em teorias do conhecimento e de currículo para o avanço nesses campos.

Todavia, é animador constatar a convergência e um expressivo consenso entre teóricos críticos e pós-críticos de currículo acerca da política da BNCC, das limitações da Pedagogia das Competências para a educação básica e da urgência de um currículo integrado que dê conta dessa realidade curricular brasiliana.

Quanto à terceira pergunta de pesquisa, para a qual estimamos o grau de adesão dos documentos subnacionais à BNCC, relembramos que o texto da Base ao mesmo tempo em que centralizou a organização do trabalho pedagógico nas avaliações externas de larga escala a favor de uma educação global, anunciou-se 
como um não currículo invocando, contraditoriamente, a complementação dos conteúdos com as especificidades locais. Essa ação gerou impasses e equívocos na modelagem curricular entre a prescrição e a orientação.

A pesquisa revelou, não obstante, as gradações de níveis prescritos em comparação aos contextos gerais dos documentos e à valoração dos "temas favoráveis à prescrição" e "temas favoráveis à orientação", uma vez que $51 \%$ das propostas $(n=14)$ apresentam baixo grau de adesão à Base, pois a assimilaram mais como orientação. Outros $33 \%$, estimados com o grau médio $(n=9)$, demonstram traços de ambas as referenciações; e, por último, 11\% dos currículos subnacionais $(n=3)$ têm alto grau de adesão à política curricular de padronização tecnicista.

As políticas educacionais e curriculares induzidas pelas prescrições da BNCC e dos currículos subnacionais não se findam com a materialização desses documentos, posto que, entre a prescrição e a ação, há um universo que pode estar muito próximo e harmônico ou anos-luz de distanciamento (SACRISTÁN, 2000). Em face disso, reiteramos a necessidade de pesquisas longitudinais que acompanhem a implementação e os impactos, explícitos e latentes, da BNCC para a formação docente, a organização do trabalho pedagógico e a didática em sala de aula, com vistas ao fortalecimento da escola pública, laica e de qualidade para todos. Assim, para transferir à prática da ação social o que está na prática das palavras, é preciso que toda a sociedade e cada um de seus agentes socioestatais, com seus interesses e estratégias, continuem o jogo da Ação Pública, o que demanda clareza política, compreensão das regras do jogo, coalizões e recursos intelectivos. 


\section{REFERÊNCIAS}

\section{Referências Bibliográficas:}

ABRUCIO, Fernando Luiz; FRANZESE, Cibele; SANO, Hironobu. Trajetória recente da cooperação e coordenação no Federalismo Brasileiro. In: CARDOSO JR, José Celso; BERCOVICI, Gilberto. República, democracia e desenvolvimento: contribuições ao Estado brasileiro contemporâneo. Brasília: IPEA, 2013.

AGOSTINI, Camila Chiodi. As artes de governar o currículo da educação infantil: a Base Nacional Comum Curricular em discussão. 2017. 166 f. Dissertação (Mestrado Interdisciplinar em Ciências Humanas) - Universidade Federal da Fronteira do Sul, Campus Erechim, Erechim, Santa Catarina, 2017.

ANTUNES, Ricardo. O privilégio da servidão. São Paulo: Boitempo, 2018.

APPLE, Michael. Ideologia e currículo. Porto Alegre: Artmed, 2006.

ARAÚJO, Macilene Pereira. Teias curriculares e ensino de biologia: reflexões com base nas questões do ENEM a partir da Argumentação. 2017. 74 f. Dissertação (Programa de Pós-Graduação em Ensino de Ciências e Educação Matemática PPGECEM) - Universidade Estadual da Paraíba, Campina Grande, 2017.

ARAUJO, Tania Bacelar. Desenvolvimento regional brasileiro e políticas públicas federais no governo Lula. In: SADER, Emir. (Org.). 10 anos de governos pósneoliberais no Brasil: Lula e Dilma. São Paulo: Boitempo; Rio de Janeiro: FLACSO Brasil, 2013.

ARRETCHE, Marta Teresa Silva. Estado federativo e políticas sociais: determinantes da descentralização. Rio de Janeiro: Revan; São Paulo: FAPESP, 2000.

BARDIN, Laurence. Análise de conteúdo. 5. ed. Lisboa, Portugal: Edições 70, 2009.

BAUMAN, Zygmunt. Retrotopia. Tradução de: Renato Aguiar. 1. ed. Rio de Janeiro: Zahar, 2017.

BORGES, Lívia Freitas Fonseca. Eixo estruturante e transversalidade: elementos orientadores dos currículos da formação de profissionais da educação. EdUECE, v. 4, p. 1181-1199, 2014.

BRITISH COUNCIL. Políticas públicas para o ensino de inglês: um panorama das experiências na rede pública brasileira. São Paulo. 2019.

BURGOS, Marcelo Tadeu Baumann; BELLATO, Caíque Cunha. Gerencialismo e pós-gerencialismo: em busca de uma nova imaginação para as políticas 
educacionais no Brasil. Sociologia Antropologia, Rio de Janeiro, v. 09.03, p. 919943, set./dez. 2019.

CAMPOS, Ana Cristina. Ensino básico tem $73,5 \%$ dos alunos em escolas públicas, diz IBGE. Agência Brasil, Rio de Janeiro, 21 dez. 2017. Disponível em: http://agenciabrasil.ebc.com.br/educacao/noticia/2017-12/ensino-basico-tem-735dos-alunos-em-escolas-publicas-diz-ibge. Acesso em: 5 ago. 2018.

CAPES. Produção técnica: grupo de trabalho. Brasília/DF: Coordenação de Aperfeiçoamento de Pessoal de Nível Superior, 2019.

CENPEC. Currículos para os anos finais do ensino fundamental: concepções, modos de implantação e usos. São Paulo, SP: Centro de Estudos e Pesquisas em Educação, Cultura e Ação Comunitária, 2015.

CHAUI, Marilena. O que é ideologia. 18. ed. São Paulo: Editora Brasiliense, 1985.

CIERVO, Tássia Joana Rodrigues. A centralidade das competências socioemocionais nas políticas curriculares contemporâneas no Brasil. 2019. 154 f. Dissertação (Mestrado em Educação) - Universidade do Vale do Rio dos Sinos, Programa de Pós-Graduação em Educação, 2019.

COSTA. Raquel. Estado, políticas de educação e ensino: em debate a Base Nacional Comum Curricular (2015-2017). 2018. 161 f. Dissertação (Mestrado em Ensino) - Universidade Estadual do Paraná, Campus de Paranavaí, UNESPAR, Paraná, 2018.

COSTA, Vanessa do Socorro Silva. Base Nacional Comum Curricular como política de regulação do currículo, da dimensão global ao local: o que pensam os professores? 2018. 185 f. Tese (Doutorado em Educação: Currículo) - Programa de Estudos Pós-Graduados em Educação: Currículo, Pontifícia Universidade Católica de São Paulo, São Paulo, 2018.

CRUZ, Fernanda Natasha B. Conselhos Nacionais de Políticas e Transversalidade: (des)caminhos do desenvolvimento democrático. Tese (Doutorado em Desenvolvimento, Sociedade e Cooperação Internacional) - Centro de Estudos Avançados Multidisciplinares (CEAM). Universidade de Brasília, Brasília, 2017.

CURY, Carlos Roberto Jamil; REIS, Magali; ZANARDI, Teodoro Adriano Costa. Base Nacional Comum Curricular: dilemas e perspectivas. São Paulo: Cortez, 2018.

DELORS, Jacques. Relatório para a UNESCO da Comissão Internacional sobre Educação para o século XXI. São Paulo, 1999.

DUARTE, Newton. As pedagogias do "aprender a aprender" e algumas ilusões da assim chamada sociedade do conhecimento. Revista Brasileira de Educação, Rio de Janeiro, RJ, n. 18, p. 35-40, set./dez. 2001. 
DUARTE, Newton. Os conteúdos escolares e a ressurreição dos mortos: contribuição à teoria histórico-crítica do currículo. Campinas, SP: Autores Associados, 2016.

FETTERMAN, David. Ethnography: step by step. London: Sage, 1998.

FLICK, Uwe. Qualidade na pesquisa qualitativa. Porto Alegre: Artmed, 2009.

FONSECA, Daniel José Rocha. Análise discursiva sobre a base nacional comum curricular. 2018. 89 f. Dissertação (Mestrado em Educação) - Universidade Federal de Goiás, Jataí, 2018.

FREIRE, Paulo. Pedagogia do oprimido. 64. ed. Rio de Janeiro/São Paulo: Paz e Terra, 2017.

FREITAS, Luiz Carlos. A reforma empresarial da educação: nova direita, velhas ideias. São Paulo: Expressão Popular, 2018a.

FREITAS, Luiz Carlos. Crítica da organização do trabalho pedagógico e da didática. 5. ed. Campinas, SP: Papirus, 2002.

FREITAS, Luiz Carlos. MEC: um estranho conceito de "currículo". Avaliação Educacional - Blog do Freitas, 15 mar. 2018b. Disponível em: https://avaliacaoeducacional.com/2018/03/15/mec-um-estranho-conceito-decurriculo/. Acesso em: 26 abr. 2018b.

FREITAS, Luiz Carlos. Política educacional e base nacional - final. Avaliação Educacional - Blog do Freitas, 18 set. 2015. Disponível em: https://avaliacaoeducacional.com/2015/09/18/politica-educacional-e-base-nacionalfinal-2/. Acesso em: 14 nov. 2015.

FRIGOTTO, Gaudêncio. A educação está nocauteada. [Entrevista cedida a] André Antunes. EPSJV/Fiocruz, São Paulo, 15 jun. 2018. Disponível em: http://www.epsjv.fiocruz.br/noticias/entrevista/a-educacao-esta-nocauteada. Acesso em: 17 set. 2018.

GALIAN, Cláudia Valentina Assumpção; LOUZANO, Paula Baptista Jorge. Michael Young e o campo do currículo: da ênfase no "conhecimento dos poderosos" à defesa do "conhecimento poderoso". Educação e Pesquisa, São Paulo, v. 40, p. 1109-1124, out./dez. 2014.

GRIN, Eduardo José; ABRUCIO, Fernando Luiz. Inovação no associativismo territorial no Brasil: os arranjos de desenvolvimento da educação. Redes. Santa Cruz do Sul: Universidade de Santa Cruz do Sul, v. 22, n. 3, p. 39-64, set-dez, 2017.

HALL, Stuart.; WOODWARD, Kathryn. Identidade e diferença: a perspectiva dos estudos culturais. Petrópolis/RJ: Vozes, 2000.

HELENO. Carolina Ramos. Contribuição à crítica da base nacional comum curricular: a máscara do conformismo na educação do Banco Mundial. 2017. 145 f. 
Dissertação (Mestrado Acadêmico em Educação) - Universidade Estadual de Feira de Santana, Feira de Santana, 2017.

HUNGARO, Edson Marcelo. A questão do método na constituição da teoria social de Marx. In: CUNHA, C.; SOUSA, J. V.; SILVA, M. A. (org.). O método dialético na pesquisa em educação. Campinas: Autores Associados, 2014.

LASCOUMES, Pierre; LE GALÈS, Patrick. Sociologia da ação pública. Tradução de George Sarmento. Maceió: EDUFAL, 2012.

LEPED. Em defesa da política nacional de educação especial na perspectiva da educação inclusiva. Campinas: Laboratório de Estudos e Pesquisas em Ensino e Diferença da Faculdade de Educação da Universidade estadual de Campinas, 2018.

MACEDO, Elizabeth. Base Nacional Curricular Comum: a falsa oposição entre conhecimento para fazer algo e conhecimento em si. Educação em Revista, Belo Horizonte, v. 32, p. 45-67, abr./jum. 2016.

MAINARDES, Jefferson. A pesquisa no campo da política educacional: perspectivas teórico-epistemológicas e o lugar do pluralismo. Revista Brasileira de Educação, v. 23, p. 1-20, 2018.

MALANCHEN, Julia. Cultura, conhecimento e currículo: contribuições da pedagogia histórico-crítica. Campinas, SP: Autores Associados, 2016.

MARTINS, Adriana dos Reis. Currículo de arte na educação de tempo integral de uma escola de Palmas/TO: uma percepção institucional e dos professores. 2019.176 f. Tese (Doutorado Dinter em Artes) - Universidade Estadual Paulista "Júlio de Mesquita Filho", Instituto de Artes e Universidade Federal do Tocantins, Programa de Pós-Graduação em Artes, São Paulo, 2019.

MARX, Karl. Para a crítica da economia política. salário, preço e lucro. 0 rendimento e suas fontes. São Paulo: Abril Cultural, 1982.

MINAYO, Maria Cecílio de Souza; DESLANDES, Suely Ferreira; GOMES, Romeu. Pesquisa social: teoria, método e criatividade. Petrópolis, RJ: Vozes, 2016.

MOREIRA, Antônio Flávio Barbosa; CANDAU, Vera Maria. Indagações sobre currículo: currículo, conhecimento e cultura. Brasília: Ministério da Educação, 2007.

MOREIRA, Damares de Oliveira. Pedagogia das competências e escolas estaduais de educação profissional do Ceará: formando para o mercado. 2017. 124 f. Dissertação (Mestrado) - Universidade Federal do Ceará, Programa de Pósgraduação em Educação Brasileira, Fortaleza, CE, 2017.

MULLER, Pierre; SUREL, Yves. A análise das política públicas. Pelotas: Educat, 2002.

NAKAD, Fabricio Abdo. Desafios para a implementação da Base Nacional

Comum Curricular. 2017. 84 f. Dissertação (Mestrado em Gestão e Políticas 
Públicas) - Fundação Getúlio Vargas, Escola de Administração de Empresas de São Paulo, 2017.

OLIVEIRA, Dalila Andrade. As políticas educacionais no governo Lula: rupturas e permanências. RBPAE, v.25, n.2, p. 197-209, mai./ago. 2009.

OLIVEIRA, Rodrigo Batista. O currículo de matemática no estado de São Paulo (2008): uma construção histórica. 2018. 89 f. Dissertação (Mestrado Profissional em Ensino de Matemática) - Universidade de São Paulo, Instituto de Matemática e Estatística, São Paulo, 2018.

NETTO, José Paulo. Introdução ao estudo do método de Marx. São Paulo: Expressão popular, 2011.

PINAR, William F. Estudos curriculares: ensaios selecionados. São Paulo: Cortez, 2016.

REIS, Geovana. A gestão do currículo escolar na rede municipal de ensino de Goiânia: entre "obrigações" curriculares e práticas "autônomas". 2015. 285 f. Tese (Doutorado em Educação) - Universidade Federal de Goiás, Goiânia, 2015.

RHODES, Roderick Arthur William. The new governance: governing without government. Political Studies, v.44, n.4, p. 652-667, 1996.

RIBAS, Simone Augusta. Metodologia científica aplicada. Rio de Janeiro: Editora EdUERJ, 2004.

RIO DE JANEIRO. Contribuições críticas de especialistas. Rio de Janeiro: Secretaria de Educação, 2019a.

RIO DE JANEIRO. Documento de orientação curricular do estado do Rio de Janeiro. Rio de Janeiro: Secretaria de Educação, 2019b.

SACRISTÁN, José Gimeno. O currículo: uma reflexão sobre a prática. Tradução de Ernani F. da Fonseca Rosa. 3. ed. Porto Alegre: Artmed, 2000.

SACRISTÁN, José Gimeno; GÓMEZ, Angel I Pérez; RODRIGUEZ, Juan Bautista Martínez; SANTOMÉ, Jurjo Torres; RASCO, Félix Ângulo; MÉNDEZ, Juan Manuel Álvarez. Educar por competências: o que há de novo?. Tradução de Carlos Henrique Lucas Lima. Porto Alegre: Artmed, 2011.

SAHLBERG, Pasi. Lições finlandesas 2.0: o que a mudança educacional na Finlândia pode ensinar ao mundo?. São Paulo: SESI-SP editora, 2018.

SAMPAIO, Maria das Mercês Ferreira (Org.). Relatório de análise de propostas curriculares de ensino fundamental e ensino médio. São Paulo; Brasília: MEC/SEB, 2010.

SANTANA, Pio de Sousa. A trajetória do currículo de ensino de artes na educação básica brasileira durante o século XX: documentos mantenedores da 
desigualdade no acesso à educação escolar. 2019. 174 f. Tese (Doutorado em Artes) - Universidade Estadual Paulista "Julio de Mesquita Filho", Instituto de Artes, São Paulo, 2019.

SANTOMÉ, Jurjo Torres. Evitando o debate sobre a cultura no sistema educacional: como ser competente sem conhecimento. In: SACRISTÁN, José Gimeno et. al. Educar por competências: o que há de novo?. Porto Alegre, RS: Artmed, 2011.

SANTOMÉ, Jurjo Torres. Globalização e interdisciplinaridade: o currículo integrado. Porto Alegre: Artes Médicas, 1998.

SARTRE, Jean-Paul. Crítica da razão dialética. Rio de Janeiro: Lamparina, 2002.

SAVIANI, Dermeval. Aberturas para a história da educação: do debate teóricometodológico no campo da história ao debate sobre a construção do sistema nacional de educação no Brasil. Campinas, SP: Autores associados, 2013a.

SAVIANI, Dermeval. Aprender a aprender: um slogan para a ignorância. [Entrevista cedida à] Fundação Astrojildo Pereira. Boletim Combate Racismo Ambiental, 08 fev. 2016a. Disponível em: https://racismoambiental.net.br/2016/02/08/aprender-aaprender-um-slogan-para-a-ignorancia-entrevista-com-demerval-saviani/. Acesso em: 25 mar. 2018.

SAVIANI, Demerval. Educação escolar, currículo e sociedade: o problema da Base Nacional Comum Curricular. Revista Movimento - Revista de Educação, Rio de Janeiro, ano 3, n. 4, p. 54-84, 2016 b.

SAVIANI, Dermeval. Escola e democracia. 42. ed. Campinas: Autores Associados, 2012.

SAVIANI, Dermeval. Histórias das idéias pedagógicas no Brasil. 3. ed. Campinas, SP: Autores Associados, 2010.

SAVIANI, Dermeval. Pedagogia histórico-crítica: primeiras aproximações. 11. ed. Campinas, SP: Autores Associados, 2013b.

SILVA. Ana Paula Gomes Vieira. $O$ currículo referência da rede estadual de educação de Goiás: implicações nas atividades de professores de Ciências. 2018. 164 f. Dissertação (Mestrado em Educação em Ciências e Matemática) Universidade Federal de Goiás, Goiânia, 2018.

SILVA, Edileuza Fernandes; PAULA, Alessandra Valéria de. BNCC DO ENSINO MÉDIO E TRABALHO PEDAGÓGICO: propostas da audiência pública de Brasília. Currículo sem Fronteiras, v. 19, p. 992-1010, set./dez. 2019

SILVA, Francisco Thiago. Currículo integrado, eixo estruturante e interdisciplinaridade: uma proposta para a formação inicial de pedagogos. Brasília: Editora Kiron, 2020. 
SILVA, Francisco Thiago. Desafios e contribuições da teoria crítica para pensar o campo curricular no Brasil. Revista Projeção e Docência, v. 9, n. 1, p. 4-19, 2018.

SILVA, Francisco Thiago; BORGES, Lívia Freitas. Fonseca. Currículo e ensino de História: um estado do conhecimento no Brasil. Educação \& Realidade, Porto Alegre, v. 43, p. 1693-1723, out./dez. 2018.

SILVA, Tomaz Tadeu. Documentos de identidade: uma introdução às teorias do currículo. 2. ed. Belo Horizonte: Autêntica, 2002.

SILVA, Vanessa. Base Nacional Comum Curricular: uma análise crítica do texto da política. 2018. 198 f. Dissertação (Mestrado em Educação) - Faculdade de Educação, Universidade Federal de Pelotas, Pelotas, RS, 2018.

SIQUEIRA, Adriana Oliveira dos Santos; COLARES, Maria Lilia Imbiriba Sousa. O gestor escolar e concepções de educação integral em escolas da rede municipal de Santarém/PA. In: MACIEL, A. C.; GANZELI, P.; COSTA, S. A. Sentidos da educação integral: conceitos, programas e implicações na realidade educacional. Uberlândia: Navegando pulicações, 2018.

SOUZA, Kleber Luiz Gavião Machado. Consensos e assimetrias nas políticas curriculares para a disciplina de história no ensino médio brasileiro (19982012). 2016. 262 f. Tese (Doutorado Em Educação) - Centro de Educação, Universidade Federal do Rio Grande do Norte, Natal, 2016.

STENHOUSE, Lawrence. An introduction to curriculum research and development. Londres: Heinemann, 1975.

TRIPODI, Zara Figueiredo; SOUSA, Sandra Zákia. Do governo à governança: permeabilidade do Estado a lógicas privatizantes na educação. Cadernos de Pesquisa, v. 48, n. 167, p. 228-253, 2018.

TRIVIÑOS, Augusto Nibaldo Silva. Introdução à pesquisa em ciências sociais: a pesquisa qualitativa em educação. São Paulo: Atlas, 1987.

UNDIME. Orientações ao Dirigente Municipal de Educação: fundamentos, políticas e práticas. São Paulo: Fundação Santillana, 2017.

VIGOTSKY, Lev Semyonovich. A defectologia e o estudo do desenvolvimento e da educação da criança anormal. Educação e Pesquisa, São Paulo, v. 37, n. 4, p. 861870, 2011.

WOOD, Ellen Meiksins. Democracia contra capitalismo: a renovação do materialismo histórico. São Paulo: Boitempo, 2003.

WOOD, Ellen Meiksins. Em defesa da história: o marxismo e a agenda pósmoderna. Crítica Marxista, São Paulo, Brasiliense, v. 1, p. 118-127, 1996. 
WOODWARD, Kathryn. Identidade e diferença: uma introdução teórica e conceitual. In: HALL, S.; WOODWARD, K. Identidade e diferença: a perspectiva dos estudos culturais. Tradução de Tomaz Tadeu da Silva. Petrópolis: Editora Vozes, 2000.

YOUNG, Michael F. D. Conhecimento e Currículo na Sociologia da Educação. In: YOUNG, Michael F. D. Conhecimento e currículo: do socioconstrutivismo ao realismo social na sociologia da educação. Porto, PT: Porto Editora, 2010.

YOUNG, Michael F. D. O futuro da educação em uma sociedade do conhecimento: 0 argumento radical em defesa de um currículo centrado em disciplinas. Revista Brasileira de Educação, v. 16, p. 609-623, set./dez. 2011.

\section{Referências Documentais:}

ACRE. Currículo de referência único do Acre. Acre: Secretaria de Estado da Educação, Cultura e Esportes, 2019.

AGB. Carta ao Conselho Nacional de Educação. Brasília, DF: Associação de Geográfos Brasileiros. 14 set. 2018. Disponível em:

http//portal.mec.gov.br/component/content/article?id=70301. Acesso em: 26 out. 2018.

ALAGOAS. Referencial curricular de Alagoas. Alagoas: Secretaria de Estado da Educação de Alagoas, 2019.

AMAPÁ. Referencial curricular amapaense. Amapá: Secretaria de Estado da Educação do Amapá. 2018.

AMAZONAS. Referencial curricular amazonense. Amazonas: Secretaria de Estado de Educação do Amazonas, 2019.

ANFOPE. Carta ao Conselho Nacional de Educação. Brasília, DF: Associação Nacional pela Formação dos Profissionais da Educação. 14 set. 2018. Disponível em: http//portal.mec.gov.br/component/content/article?id=70301. Acesso em: 26 out. 2018.

ANPED. Nota das entidades educacionais ao CNE e de agradecimento a Marcia Angela Aguiar e Malvina Tuttman. 8 out. 2018. Disponível em: http://www.anped.org.br/news/nota-das-entidades-educacionais-ao-cne-e-deagradecimento-marcia-angela-aguiar-e-malvina. Acesso em: 17 dez. 2018.

APEOESP. Abaixo-assinado ao Conselho Nacional de Educação. Brasília, DF: Sindicato dos Professores do Ensino Oficial do Estado de São Paulo, 14 set. 2018. Disponível em: http//portal.mec.gov.br/component/content/article?id=70301. Acesso em: 26 out. 2018. 
BAHIA. Documento curricular referencial da Bahia. Bahia Secretaria da Educação da Bahia, 2019.

BRASIL. [Constituição (1988)]. Constituição da República Federativa do Brasil de 1988. Diário Oficial da União: República Federativa do Brasil: seção 1, p. 1, 5 out. 1988.

BRASIL. Decreto n. 2.208, de 17 de abril de 1997. Regulamenta o $\S 2^{\circ}$ do art. 36 e os arts. 39 a 42 da Lei n. 9.394, de 20 de dezembro de 1996, que estabelece as diretrizes e bases da educação nacional. Diário Oficial da União: República Federativa do Brasil: seção: 1, Brasília, DF, p. 7760, 18 abr. 1997.

BRASIL. Decreto n. 5.154, de 23 de julho de 2004. Regulamenta o $\S 2^{\circ}$ do art. 36 e os arts. 39 a 41 da Lei n. 9.394, de 20 de dezembro de 1996, que estabelece as diretrizes e bases da educação nacional, e dá outras providências. Diário Oficial da União: República Federativa do Brasil: seção: 1, Brasília, DF, p. 18, 26 jul. 2004.

BRASIL. Emenda Constitucional n. 59/2009. Acrescenta $\S 3^{\circ}$ ao art. 76 do Ato das Disposições Constitucionais Transitórias para reduzir, anualmente, a partir do exercício de 2009, o percentual da Desvinculação das Receitas da União incidente sobre os recursos destinados à manutenção e desenvolvimento do ensino de que trata 0 art. 212 da Constituição Federal, ... Diário Oficial da União: República Federativa do Brasil: seção: 1, Brasília, DF, p. 8, 12 nov. 2009a.

BRASIL. Lei oㅜ 5.692, de 11 de agosto de 1971. Fixa Diretrizes e Bases para o ensino de $1^{\circ}$ e $2^{\circ}$ graus. Diário Oficial da União: seção 1, Brasília, DF, p. 6377, 12 ago. 1971.

BRASIL. Lei no 9.131, de 24 de novembro de 1995. Altera dispositivos da Lei no 4.024, de 20 de dezembro de 1961, e dá outras providências. Diário Oficial da União: edição extra, 25 nov. 1995a.

BRASIL. Lei no 9.394, de 20 de dezembro de 1996. Lei de Diretrizes e Bases da Educação Nacional. Diário Oficial da União: seção 1, Brasília, DF, ano 139, n.8, p. 27833, 23 dez. 1996.

BRASIL. Lei no 10.832, de 29 de dezembro de 2003. Altera o $\S 1$ e e o seu inciso II do art. 15 da Lei o 9.424, de 24 de dezembro de 1996, e o art. 2ㅇ da Lei oㅜ 9.766, de 18 de dezembro de 1998, que dispõem sobre o Salário-Educação. Diário Oficial da União: seção 1, Brasília, DF, p. 1, 30 dez. 2003.

BRASIL. Lei no 12.061, de 27 de outubro de 2009. Altera o inciso II do art. 4ํㅜ e o inciso VI do art. 10 da Lei n. 9.394, de 20 de dezembro de 1996, para assegurar o acesso de todos os interessados ao ensino médio público. Diário Oficial da União: seção 1, Brasília, DF, p. 1, 28 out. 2009b.

BRASIL. Lei no 13.005, de 25 de junho de 2014. Aprova o Plano Nacional de Educação - PNE e dá outras providências. Diário Oficial da União: seção 1 Edição Extra - Brasília, DF, p. 1, 26 jun. 2014a. 
BRASIL. Lei no 13.415, de 16 de fevereiro de 2017. Altera as Leis nos 9.394, de 20 de dezembro de 1996, que estabelece as diretrizes e bases da educação nacional; e 11.494, de 20 de junho 2007, que regulamenta o Fundo de Manutenção e Desenvolvimento da Educação Básica e de Valorização dos Profissionais da Educação; ... Diário Oficial da União: seção 1, Brasília, DF, p. 1, 17 fev. $2017 a$.

BRASIL. Ministério da Administração Federal e Reforma do Estado. Plano diretor de reforma do aparelho do Estado. Presidência da República. Brasília, DF, 1995b.

BRASIL. Ministério da Educação. Base Nacional Comum Curricular. Brasília, DF, 2016a. Disponível em: http://undimesc.org.br/download/2a-versao-base-nacionalcomum-curricular/. Acesso em: 16 mai. 2018.

BRASIL. Ministério da Educação. Base Nacional Comum Curricular: Educação Infantil e Ensino Fundamental. Diário Oficial da União: seção: 1, Brasília, DF, p. 42, 22 dez. 2016b.

BRASIL. Ministério da Educação Base Nacional Comum Curricular: Ensino Médio. Diário Oficial da União: seção: 1, Brasília, DF, ano 155, p. 146, 21 dez. 2017b.

BRASIL. Ministério da Educação. Instituto Nacional de Estudos e Pesquisas Educacionais Anísio Teixeira. Portaria o 366 de 29 de abril de 2019. Estabelece as diretrizes de realização do Sistema de Avaliação da Educação Básica (SAEB) no ano de 2019. Diário Oficial da União: edição 83, seção 1, p. 47. Brasília, DF, 2 mai. 2019a.

BRASIL. Ministério da Educação. A BNCC e a Gestão Escolar. Brasília. 2020. Disponível em:http://avamec.mec.gov.br/\#/instituicao/seb/curso/2769/visualizar. Acessado em: 26 mar. 2020

BRASIL. Ministério da Educação. O sistema nacional de educação. SASE/MEC, Brasília, 2014b.

BRASIL. Ministério da Educação. Pátria educadora: a qualificação do Ensino Básico como obra de construção Nacional. Brasília: Secretaria de Assuntos Estratégicos da Presidência da República. 2015a.

BRASIL. Ministério da Educação. Portaria no 331 de 5 de abril de 2018. Institui o Programa de Apoio à Implementação da Base Nacional Comum Curricular ProBNCC e estabelece diretrizes, parâmetros e critérios para sua implementação. Diário Oficial da União: seção 1, Brasília, DF, p. 114, 06 abr. $2018 a$.

BRASIL. Ministério da Educação. Portaria ํo 757, de 3 de abril de 2019. Altera a Portaria ํㅡ 268, de 22 de março de 2018, que cria o Comitê Nacional de Implementação da Base Nacional Comum Curricular - BNCC. Diário Oficial da União: seção 1, Brasília-DF, p. 27, 04 abr. 2019b.

BRASIL. Ministério da Educação. Portaria o 592 de 17 de junho de 2015. Institui a Comissão de Especialistas para a Elaboração de Proposta da Base Nacional 
Comum Curricular. Diário Oficial da União: seção 1, Brasília, DF, p. 16, 18 jun. $2015 b$.

BRASIL. Ministério da Educação; Conselho Nacional de Educação. Audiências públicas sobre a Base Nacional Comum Curricular. Caderno Técnico. Brasília, DF, 2018b.

BRASIL. Ministério da Educação; Conselho Nacional de Educação. Resolução CNE/CEB no 3/2018. Atualiza as Diretrizes Curriculares Nacionais para o Ensino Médio, observadas as alterações introduzidas na LDB pela Lei no 13.415/2017. Diário Oficial da União: República Federativa do Brasil: seção 1, Brasília, DF, p. 49, 21 nov. 2018c.

BRASIL. Ministério da Educação; Conselho Nacional de Educação. Resolução $\mathrm{CNE} / \mathrm{CP}$ oㅡ 2/2019. Define as Diretrizes Curriculares Nacionais para a Formação Inicial de Professores para a Educação Básica e institui a Base Nacional Comum para a Formação Inicial de Professores da Educação Básica (BNC-Formação). Diário Oficial da União: República Federativa do Brasil: seção:1, Brasília, DF, 23 dez. 2019c.

CEARÁ. Documento curricular referencial do Ceará. Ceará: Secretaria da Educação do Ceará, 2018.

COMITÊ NACIONAL PELO ENSINO RELIGIOSO NO BRASIL. Manifesto ao Conselho Nacional de Educação. Brasília, DF: Comitê Nacional pelo Ensino Religioso no Brasil, 14 set. 2018. Disponível em:

http//portal.mec.gov.br/component/content/article?id=70301. Acesso em: 26 out. 2018.

DISTRITO FEDERAL. Lei no 3.218, de 05 de novembro de 2003. Dispõe sobre a universalização da Educação Inclusiva nas escolas da rede pública de ensino do Distrito Federal, e dá outras providências. Diário Oficial do Distrito Federal: seção 1, Brasília, DF, p. 2, 10 nov. 2003.

DISTRITO FEDERAL. Proposta pedagógica: Centro Interescolar de Línguas de Brasília (CIL 1 de Brasília). 2002.

DISTRITO FEDERAL. Secretaria de Estado de Educação do Distrito Federal. Currículo em Movimento do Distrito Federal, 2018.

ESPÍRITO SANTO. Currículo do Espírito Santo. Área de conhecimento: Ciências Humanas. Espírito Santo: Secretaria da Educação do Espírito Santo, 2018.

FENEP. Carta ao Conselho Nacional de Educação. Brasília, DF: Federação Nacional das Escolas Particulares: 14 set. 2018. Disponível em: http//portal.mec.gov.br/component/content/article?id=70301. Acesso em: 26 out. 2018.

GOIÁS. Documento curricular para Goiás. Goiás: Secretaria de Estado da Educação do Goiás, 2018. 
IFB. Relatório ao Conselho Nacional de Educação. Brasília, DF: Instituto Federal Baiano, 14 set. 2018. Disponível em:

http//portal.mec.gov.br/component/content/article?id=70301. Acesso em: 26 out. 2018.

MARANHÃO. Documento curricular do território maranhense. Maranhão: Secretaria de Educação do Governo do Maranhão, 2018.

MATO GROSSO. Proposta Curricular do estado de Mato Grosso. Mato Grosso: Secretaria de Estado de Educação de Mato Grosso, 2018.

MATO GROSSO DO SUL. Currículo de referência de Mato Grosso do Sul. Mato Grosso do Sul: Secretaria de Estado de Educação do Mato Grosso do Sul, 2018.

MINAS GERAIS. Currículo de referência de Minas Gerais. Minas Gerais:

Secretaria de Estado de Educação de Minas Gerais, 2018.

PARÁ. Documento Curricular do estado do Pará. Pará: Secretaria de Estado da Educação, 2018.

PARAÍBA. Proposta Curricular do estado da Paraíba. Paraíba: Secretaria da Educação e da Ciência e Tecnologia, 2018.

PARANÁ. Referencial curricular do Paraná: Princípios, Direitos e Orientações. Paraná: Secretaria de Estado da Educação e do Esporte, 2018.

PERNAMBUCO. Currículo de Pernambuco. Pernambuco: Secretaria de Educação e Esportes, 2018.

PIAUÍ. Currículo do Piauí: um marco para a educação do nosso estado. Piauí: Secretaria de Estado da Educação do Piauí, 2019.

RIO GRANDE DO NORTE. Documento curricular do Rio Grande do Norte. Rio Grande do Norte: Secretaria de estado da educação, da cultura, do esporte e do lazer, 2018.

RIO GRANDE DO SUL. Referencial Curricular Gaúcho. Rio Grande do Sul: Secretaria da Educação, 2018.

RORAIMA. Documento curricular de Roraima. Roraima: Secretaria da educação e desportos, 2019.

SANTA CATARINA. Currículo Base da Educação Infantil e do Ensino Fundamental do Território Catarinense. Santa Catarina: Secretaria de Estado da Educação, 2019.

SÃO PAULO. Currículo Paulista. São Paulo: Secretaria da Educação do estado de São Paulo, 2019. 
SBPC. Carta ao Conselho Nacional de Educação. Brasília, DF: Sociedade Brasileira para o Progresso da Ciência, 14 set. 2018. Disponível em:

http//portal.mec.gov.br/component/content/article?id=70301. Acesso em: 26 out. 2018.

SERGIPE. Currículo de Sergipe: integrar e construir. Sergipe: Secretaria de Estado da Educação, do Esporte e da Cultura, 2018.

TOCANTINS. Documento Curricular Tocantins. Tocantins: Secretaria da Educação, Juventude e Esportes, 2019.

UMBRASIL. Carta ao Conselho Nacional de Educação. Brasília, DF: União Marista do Brasil, 14 set. 2018. Disponível em:

http//portal.mec.gov.br/component/content/article?id=70301. Acesso em: 26 out. 2018. 


\section{APÊNDICES}

\section{APÊNDICE A - ROTEIRO PARA A ANÁLISE DOCUMENTAL}

\section{Objetivo:}

Compreender de que forma as unidades da Federação atualizaram seus currículos ante as prescrições da BNCC El/EF.

\section{Documentos:} Fundamental (BRASIL, 2016).

- Documentos curriculares das unidades da Federação para a Educação Infantil e do Ensino Fundamental.

\section{Eixos de análise:}

> Política pública educacional e curricular.

> Concepção de Educação e de Currículo.

\section{Descritores:}

Aspectos gerais: nome; número de páginas; datas de envio pela Secretaria de Educação e de aprovação pelo Conselho de Educação; abrangência; e adesão ao ProBNCC.

$>$ Concepções de Educação e de Currículo: princípios; proposta pedagógica; e organizador curricular.

$>\quad$ Adesão à BNCC: temas favoráveis a prescrição; e temas favoráveis a orientação. 


\section{APÊNDICE B - APROVAÇÃO DOS CURRÍCULOS SUBNACIONAIS}

Quadro 20 - Aprovação dos currículos subnacionais

\begin{tabular}{|c|c|}
\hline \multicolumn{2}{|c|}{ Aprovação dos currículos subnacionais } \\
\hline CEE/AC & Resolução no 136/2019. \\
\hline CEE/AL & Resolução no 1/2019. \\
\hline CEE/AM & Resolução nº 098/2019. \\
\hline CEE/AP & Parecer no 111/2018. \\
\hline CEE/BA & Parecer no 196/2019. \\
\hline CEE/CE & Parecer nำ0906/2018. \\
\hline CEDF & Portaria no 389/2018. \\
\hline CEE/ES & Resolução no 5.190/2018. \\
\hline CEE/GO & Resolução no 8/2018. \\
\hline CEE/MA & Resolução nํ31/2018. \\
\hline CEE/MG & Parecer no 937/2018. \\
\hline CEE/MS & Parecer $n^{0} 351 / 2018$. \\
\hline CEE/MT & Parecer no 001/2018. \\
\hline CEE/PA & Resolução nº 769/2018. \\
\hline CEE/PB & Resolução nำ 500/2018 \\
\hline CEE/PE & Parecer no 114/2018. \\
\hline CEE/PI & Resolução nº 097/2019. \\
\hline CEE/PR & Portaria nº 03/2018. \\
\hline CEE/RJ & Portaria no 3748/2019. \\
\hline CEE/RN & Parecer no 102/2018. \\
\hline CEE/RO & Resolução nº 1233/2018. \\
\hline CEE/RR & Parecer no 13/2019. \\
\hline CEE/RS & Resolução nº 345/2018. \\
\hline CEE/SC & Resolução nº 070/2019. \\
\hline CEE/SE & Resolução no 4/2018. \\
\hline CEE/SP & Indicação no 179/2019. \\
\hline $\mathrm{CEE} / \mathrm{TO}$ & Resolução no 024/2019. \\
\hline
\end{tabular}

Fonte: Elaborado pela autora (2020) 


\section{APÊNDICE C - Organização currícular}

\section{Quadro 21 - Organizador curricular}

\begin{tabular}{|c|c|c|}
\hline UF & PROPOSTA PEDAGÓGICA & ORGANIZADOR CURRICULAR \\
\hline$A C$ & $\begin{array}{l}<\text { HÍBRIDA }>> \\
\text { Pedagogia do Aprender a Aprender; e "É nesta capacidade } \\
\text { comunicativa e dialógica que enxergamos a contribuição da } \\
\text { Educação Física na formação dos alunos: a possibilidade de um } \\
\text { aluno que se quer autônomo e crítico, participativo e emancipado na } \\
\text { construção do ambiente de convívio social, a partir das práticas da } \\
\text { cultura corporal." (p. 360). }\end{array}$ & $\begin{array}{l}\text { El:Campos de experiência/Direitos de aprendizagem e desenvolvimento/Avaliação. } \\
\text { EF: Objetivos / Conteúdos / Propostas de atividades / Formas de avaliação. }\end{array}$ \\
\hline $\mathrm{AL}$ & $\begin{array}{l}\text { PeECLÉTICA }>> \\
\text { Pedagogia do Aprender a Aprender; e "Dessa forma, cabe-nos } \\
\text { refletir: Que cidadão queremos formar? sujeitos autônomos, } \\
\text { criativos, que consigam interagir, que possam aprofundar uma } \\
\text { reflexão de forma crítica e promover mudanças na sua realidade. É } \\
\text { deste cidadão que o mundo atual necessita e para quem nosso } \\
\text { referencial precisa oportunizar." (p. 55). }\end{array}$ & $\begin{array}{l}\text { El: Campos de experiência/Objetivos de aprendizagem e desenvolvimento/ } \\
\text { Desdobramentos Didático-Pedagógicos - DesDP*. } \\
\text { EF: Campos de atuação ou Unidades Temáticas/Práticas de Linguagem / Objeto de } \\
\text { conhecimento/Habilidades/Desdobramentos Didático-Pedagógicos- DesDP*. }\end{array}$ \\
\hline AM & $\begin{array}{l}\text { Pedagogia das Competências; e "Sigamos juntos na luta por uma } \\
\text { educação emancipadora!"(p. 17). }\end{array}$ & $\begin{array}{l}\text { El: Eixos Estruturantes (Interações e brincadeira/Campos de experiência/Objetivos de } \\
\text { aprendizagem e desenvolvimento. } \\
\text { EF: Campos de atuação ou Unidades temáticas (Eixos)/(Práticas de } \\
\text { linguagem)/Competências/Habilidades/Objetos de conhecimento/Detalhamento dos } \\
\text { objeto de conhecimento*. }\end{array}$ \\
\hline AP & $\begin{array}{l}\qquad<\text { HÍBRIDA } \gg> \\
\text { Pedagogia Histórico-Crítica e Psicologia Histórico-Cultural para } \\
\text { Educação Física; e Pedagogia do Aprender a Aprender para os } \\
\text { demais componentes. }\end{array}$ & $\begin{array}{l}\text { El: Campos de experiência/Objetivos de aprendizagem e desenvolvimento/ } \\
\text { Experiências. } \\
\text { EF: Práticas de linguagem ou Unidades temáticas (eixo)/Objetos de } \\
\text { conhecimento/Habilidades. }\end{array}$ \\
\hline BA & $\begin{array}{l}\text { Pedagogia Histórico-Crítica para a Educação Ambiental; e } \\
\text { Pedagogia das Competências para os demais componentes. }\end{array}$ & $\begin{array}{l}\text { El: Transversalidade relacionada com os conceitos fundantes/Transversalidade } \\
\text { relacionada com as competências/Campos de experiência / Orientações } \\
\text { metodológicas. } \\
\text { EF: Práticas de linguagem ou Unidades temáticas (eixos) / Competências específicas / } \\
\text { Objeto(s) de conhecimento / Habilidades. }\end{array}$ \\
\hline
\end{tabular}

Fonte: Elaborado pela autora (2020)

* Novas habilidades criadas pelo estado. 
Quadro 21 - Organizador curricular (continuação)

\begin{tabular}{|c|c|c|}
\hline UF & PROPOSTA PEDAGÓGICA & ORGANIZADOR CURRICULAR \\
\hline CE & $\begin{array}{l}\langle<\text { ECLÉTICA }>> \\
\text { Pedagogia do Aprender a Aprender; e "O currículo da escola do } \\
\text { campo tem por base as seguintes referências para todos os } \\
\text { componentes curriculares, sejam da base comum ou da parte } \\
\text { diversificada: [...] Participação e auto-organização - }[\ldots] \\
\text { indispensáveis no processo de socialização e do exercício da } \\
\text { cidadania, da emancipação, da libertação e da humanização." (p. } \\
86) \text {. }\end{array}$ & $\begin{array}{l}\text { El: Faixa / Direitos de aprendizagem e desenvolvimento na El / Campos de } \\
\text { experiência / Objetivos de aprendizagem e desenvolvimento / Organização e } \\
\text { integração das experiências. } \\
\text { EF: Ano / Campos de atuação ou Unidades temáticas (Eixos) / (Práticas de } \\
\text { linguagem) / Objetos de conhecimento / Objetos específicos / Habilidades / Relação } \\
\text { dentro do próprio componente / Relação entre componentes / Competências } \\
\text { (específicas)*. }\end{array}$ \\
\hline DF & Pedagogia Histórico-Crítica e a Psicologia Histórico-Cultural. & $\begin{array}{l}\text { El: Eixos transversais / Eixos integradores / Campos de experiência / Objetivos de } \\
\text { aprendizagem e desenvolvimento. } \\
\text { EF: Eixos transversais / Eixos integradores/Objetivos / Conteúdos. }\end{array}$ \\
\hline ES & $\begin{array}{l}\qquad<\text { ECLÉTICA }>> \\
\text { Pedagogia do Aprender a Aprender; e "[...] o Espírito Santo promove } \\
\text { um currículo estruturado com identidade própria, mas legalmente } \\
\text { embasado, a fim de oportunizar educação de qualidade a todos, por } \\
\text { meio do desenvolvimento de habilidades e competências que } \\
\text { promovam caráter ético, autônomo, crítico-reflexivo e emancipado, } \\
\text { condições imprescindíveis à atuação em contextos educativos, no } \\
\text { mundo do trabalho e na vida em sociedade." (p. 10). }\end{array}$ & $\begin{array}{l}\text { El: Campos de experiência / Objetivos de aprendizagem e desenvolvimento / Dicas } \\
\text { para o planejamento / Vale observar que. } \\
\text { EF: Campo temático / Objeto do conhecimento / Habilidades / Competências } \\
\text { específicas / Possibilidades de envolvimento / Temas integradores. }\end{array}$ \\
\hline GO & Foco no desenvolvimento de Competências / Habilidades. & $\begin{array}{l}\text { El: Objetivos de aprendizagem e desenvolvimento dos Campos de experiência / } \\
\text { Sentidos, saberes e conhecimentos. } \\
\text { EF: Campos de atuação ou Unidades temáticas (Eixos) / (Práticas de linguagem) / } \\
\text { Objetos de conhecimento / Habilidades. }\end{array}$ \\
\hline MA & $\begin{array}{l}\qquad<\text { ECLÉTICA>> } \\
\text { Pedagogia das Competências; e "[...] apropriação do conhecimento } \\
\text { científico, cultural e social que é patrimônio da humanidade." (p. 17) } \\
\text { "Objetiva-se um currículo que seja expressão das relações sociais, } \\
\text { na perspectiva da emancipação do indivíduo, e que não se reduza a } \\
\text { um amontoado de conteúdos sem intencionalidade de construir uma } \\
\text { formação humana e libertadora." (p. 18). }\end{array}$ & $\begin{array}{l}\text { El: Campos de experiência / Objetivos de aprendizagem e desenvolvimento / } \\
\text { Possibilidades de experiências. } \\
\text { EF: Práticas de linguagem (Eixos) / (Campos) / (Linguagem artística) / Unidades } \\
\text { temáticas / Objetos de conhecimento / Habilidades / Atividades sugeridas }{ }^{*} \text {. }\end{array}$ \\
\hline MG & $\begin{array}{l}\qquad<\text { ECLÉTICA }>> \\
\text { Pedagogia do Aprender a Aprender; e "[...] construir novas posturas } \\
\text { e práticas pedagógicas, despertar a inquietude epistemológica e o } \\
\text { inconformismo diante das desigualdades e, apostar nos processos } \\
\text { de emancipação social." (p. 77). }\end{array}$ & $\begin{array}{l}\text { El: Campos de experiência / Direitos de aprendizagem / Objetivos de aprendizagem e } \\
\text { desenvolvimento / Orientações Didáticas / Experiências propostas*. } \\
\text { EF: Campos de atuação (Eixos) / Práticas de linguagem (Unidades temáticas) / } \\
\text { Objetos de conhecimento / Habilidades. }\end{array}$ \\
\hline
\end{tabular}

Fonte: Elaborado pela autora (2020)

* Novas habilidades criadas pelo estado. 
Quadro 21 - Organizador curricular (continuação)

\begin{tabular}{|c|c|c|}
\hline UF & PROPOSTA PEDAGÓGICA & ORGANIZADOR CURRICULAR \\
\hline \multirow[b]{2}{*}{ MS } & $<<E C L E ́ T I C A \gg>$ & \multirow{2}{*}{$\begin{array}{l}\text { El: Campos de experiência / Objetivos de aprendizagem e desenvolvimento / Ações } \\
\text { didáticas. } \\
\text { EF: Campos de atuação (Eixos) / Práticas de linguagem (Unidades temáticas) / } \\
\text { Objetos de conhecimento / Habilidades / Ações didáticas. }\end{array}$} \\
\hline & $\begin{array}{l}\text { Desenvolvimento de Competências; e "A prática do professor, } \\
\text { portanto, deverá estar pautada no desenvolvimento de habilidades, } \\
\text { no conhecimento científico e na promoção de atitudes e valores para } \\
\text { a convivência no século XXI." (p. 22). }\end{array}$ & \\
\hline \multirow[b]{2}{*}{ MT } & <<ECLÉTICA >> & \multirow[b]{2}{*}{$\begin{array}{l}\text { El: Campos de experiência / Objetivos de aprendizagem e desenvolvimento. } \\
\text { EF: Campos de atuação (Eixos) / Práticas de linguagem (Unidades temáticas) / } \\
\text { Objetos de conhecimento / Habilidades / Ano/Faixa. }\end{array}$} \\
\hline & $\begin{array}{l}\text { Pedagogia das Competências; e Letramento crítico: "Considerando } \\
\text { que neste documento, teremos como um dos eixos norteadores os } \\
\text { Multiletramentos [...]". } \\
\text { (p. 37). }\end{array}$ & \\
\hline \multirow[b]{2}{*}{ PA } & $<<$ LITERAL $>>$ & \multirow[b]{2}{*}{$\begin{array}{l}\text { El: Campos de experiência / Objetivos de aprendizagem e desenvolvimento / } \\
\text { Aprendizagens a serem vivenciadas pelos bebês. } \\
\text { EF: Eixo / Subeixo / Objetivos de aprendizagem (Linguagem) / Habilidades. }\end{array}$} \\
\hline & $\begin{array}{l}\text { Pedagogias Críticas: "[...] pedagogias construídas historicamente } \\
\text { resultante das experiências transmitidas de geração a geração "Sob } \\
\text { essa perspectiva curricular está a defesa da construção de uma } \\
\text { consciência crítica na emancipação do Homem e do controle social } \\
\text { que a escola assumiu; para tal empenho, o currículo crítico é aquele } \\
\text { que dispõe de uma montagem do cotidiano social vivido por aqueles } \\
\text { que frequentam a sala de aula, uma vez que a educação formal } \\
\text { historicamente valorizou o saber científico como aquele que atende } \\
\text { às demandas humanas." (p. 15). }\end{array}$ & \\
\hline \multirow[b]{2}{*}{ PB } & $<$ <ECLÉTICA $>>$ & \\
\hline & $\begin{array}{l}\text { Pedagogia das Competências; e "A proposta de educação freiriana } \\
\text { conduz para a emancipação do sujeito, tendo como base o diálogo, } \\
\text { a presença das relações e a devida importância aos saberes que } \\
\text { cada um traz, para que novos conhecimentos sejam apreendidos." } \\
\text { (p. 515). }\end{array}$ & $\begin{array}{l}\text { El: Campos de experiência / Objetivos de aprendizagem e desenvolvimento. } \\
\text { EF: Objetivos de aprendizagem / Conteúdos / Habilidades BNCC } \\
\text { (Comentários/Sugestões metodológicas). }\end{array}$ \\
\hline \multirow[b]{2}{*}{$\mathrm{PE}$} & $<$ ECLÉTICA $>>$ & \multirow[b]{2}{*}{$\begin{array}{l}\text { El: Objetivos de aprendizagem e desenvolvimento / Direitos de aprendizagem e } \\
\text { desenvolvimento / Campos de experiência. } \\
\text { EF: Práticas de linguagem ou Unidades temáticas / Campos de atuação (Campos } \\
\text { temáticos) / Objetos do Conhecimento/Habilidades PE*. }\end{array}$} \\
\hline & $\begin{array}{l}\text { Pedagogia do Aprender a Aprender; e "[...] o ensino de Ciências } \\
\text { passa a contar com uma estrutura curricular que favorece a } \\
\text { aprendizagem significativa do conhecimento historicamente } \\
\text { acumulado, relacionando atividades humanas com tecnologia, } \\
\text { sociedade, valores humanos e concepções de Ciências." (p. 429). }\end{array}$ & \\
\hline
\end{tabular}

Fonte: Elaborado pela autora (2020)

* Novas habilidades criadas pelo estado. 
Quadro 21 - Organizador curricular (continuação)

\begin{tabular}{|c|c|c|}
\hline UF & PROPOSTA PEDAGÓGICA & ORGANIZADOR CURRICULAR \\
\hline $\mathrm{PI}$ & $\begin{array}{l}\qquad<\text { ECLÉTICA }>> \\
\text { Pedagogia do Aprender a Aprender; e "Assim sendo, acredita-se que } \\
\text { uma educação de qualidade, que tem como base o desenvolvimento } \\
\text { de competências e habilidades e que promova aprendizagem } \\
\text { significativa, contribui para a emancipação e melhoria na qualidade } \\
\text { de vida dos cidadãos piauienses." (p. 21). }\end{array}$ & $\begin{array}{l}\text { El: Campos de experiência / Faixa etária / Objetivos de aprendizagem e } \\
\text { desenvolvimento / Possibilidades pedagógicas. } \\
\text { EF: Práticas de linguagem (Eixo) / Unidades temáticas / Habilidades / Objetos de } \\
\text { conhecimento. }\end{array}$ \\
\hline \multirow[b]{2}{*}{ PR } & $<<$ HÍBRIDA $>>$ & \multirow{2}{*}{$\begin{array}{l}\text { El: Campos de experiência / Saberes e conhecimentos / Objetivos de aprendizagem e } \\
\text { desenvolvimento. } \\
\text { EF: Campos de atuação / Práticas de linguagem ou Unidade temática / Objetos de } \\
\text { conhecimento / Objetivos de aprendizagem. }\end{array}$} \\
\hline & $\begin{array}{l}\text { Pedagogia Histórico-Crítica para a Educação Física e Pedagogia } \\
\text { das Competências para os demais componentes curriculares. }\end{array}$ & \\
\hline \multirow[b]{2}{*}{ RJ } & $<<$ LITERAL $>>$ & \multirow{2}{*}{$\begin{array}{l}\text { El: Práticas pedagógicas que auxiliam na garantiam dos Direitos de aprendizagem em } \\
\text { Campos de experiências. } \\
\text { EF: Componente / Ano/Faixa / (eixo) /(Unidades temáticas) (Campos de atuação) } \\
\text { (Práticas de linguagem) / Objetos de conhecimento / Habilidades. }\end{array}$} \\
\hline & $\begin{array}{l}\text { Concepção pedagógica própria de cada escola a partir dos } \\
\text { princípios e das referências curriculares do Documento de } \\
\text { orientação curricular do estado do Rio de Janeiro. }\end{array}$ & \\
\hline \multirow[b]{2}{*}{$\mathrm{RN}$} & $<$ HÍBRIDA $>>$ & \multirow{2}{*}{$\begin{array}{l}\text { El: Campos de experiência / Objetivos de aprendizagem e desenvolvimento / } \\
\text { Objetivos específicos. } \\
\text { EF: Problematização / Objetos de conhecimento / Habilidades / Sugestões didáticas. }\end{array}$} \\
\hline & $\begin{array}{l}\text { Competências / Habilidades; e Teorias Críticas de educação para } \\
\text { Educação Física. }\end{array}$ & \\
\hline \multicolumn{3}{|r|}{ ( } \\
\hline \multirow[b]{2}{*}{$\mathrm{RR}$} & $<<$ ECLÉTICA $>>$ & \multirow{2}{*}{$\begin{array}{l}\text { El: Campos de experiência / Direitos de aprendizagem / Objetivos de aprendizagem e } \\
\text { desenvolvimento / Experiências de aprendizagem / Abordagens das experiências de } \\
\text { aprendizagem / Orientação Didática. } \\
\text { EF: Campo de atuação / Práticas de linguagem (Unidades temáticas) / Objetos de } \\
\text { conhecimento / Habilidades / Orientações didáticas/metodológicas. }\end{array}$} \\
\hline & $\begin{array}{l}\text { Pedagogia das Competências e do Aprender a Aprender; e bases } \\
\text { epistemológicas } \\
\text { "[...] enraizadas no pensamento freireano [...] com o propósito de } \\
\text { emancipação das pessoas." (p. 520). }\end{array}$ & \\
\hline \multirow[b]{2}{*}{ RS } & $<<$ LITERAL $>>$ & \multirow{2}{*}{$\begin{array}{l}\text { El: Campos de experiência/Objetivos de aprendizagem e desenvolvimento - } \\
\text { BNCC/Objetivos de aprendizagem e desenvolvimento - } \mathrm{RS}^{*} \text {. } \\
\text { EF: Campos de atuação (Unidades temáticas) / Objetos de conhecimento / } \\
\text { Habilidades -BNCC / Habilidades - RS*. }\end{array}$} \\
\hline & Foco nas Competências. & \\
\hline
\end{tabular}

Fonte: Elaborado pela autora (2020)

* Novas habilidades criadas pelo estado. 


\section{Quadro 21 - Organizador curricular (continuação)}

\begin{tabular}{|c|c|c|}
\hline UF & PROPOSTA PEDAGÓGICA & ORGANIZADOR CURRICULAR \\
\hline \multirow[b]{2}{*}{ SC } & $<<$ ECLÉTICA $>>$ & \multirow[b]{2}{*}{$\begin{array}{l}\text { El: Campos de experiências / Objetivos de aprendizagem e desenvolvimento. EF: } \\
\text { Campos de atuação / Práticas de linguagem (Unidades temáticas) / Objetos de } \\
\text { conhecimentos (imprescindíveis) / Habilidades / Conteúdos / (Destaques). }\end{array}$} \\
\hline & $\begin{array}{l}\text { Pedagogia da Competências; e "[...]alicerça-se no princípio da } \\
\text { educação integral, por entender que, por meio dela, promover-se-á } \\
\text { uma formação que visa a cidadania, a emancipação e a liberdade } \\
\text { como processos ativos e críticos que possibilitam ao estudante o } \\
\text { pleno desenvolvimento e a apropriação do conhecimento e da } \\
\text { cultura historicamente construídos, [...]" (p. 12). }\end{array}$ & \\
\hline \multirow[b]{2}{*}{ SE } & $<<$ ECLÉTICA $>>$ & \multirow{2}{*}{$\begin{array}{l}\text { El: Campos de experiência / Direitos de aprendizagem e desenvolvimento / Objetivos } \\
\text { de aprendizagem e desenvolvimento / Abordagem das experiências de aprendizagem. } \\
\text { EF: Práticas de linguagem/ Eixo (Unidades temáticas) / Objetos de conhecimento / } \\
\text { Especificação dos objetos de conhecimento / Habilidades. }\end{array}$} \\
\hline & $\begin{array}{l}\text { Pedagogia das Competências; e "[...] valorizando a busca constante } \\
\text { do conhecimento e da emancipação, o que já está expresso na } \\
\text { progressão das competências e habilidades ano a ano. (p. 119). }\end{array}$ & \\
\hline \multirow[b]{2}{*}{ SP } & $<<$ LITERAL $>>$ & \multirow{2}{*}{$\begin{array}{l}\text { El: Campos de experiências / Direitos de aprendizagem e desenvolvimento. } \\
\text { EF: Campos de atuação / Práticas de linguagem / Linguagens / Unidades temáticas } \\
\text { (Eixo) / Habilidades (Habilidades Currículo paulista)* / Objetos de conhecimento. }\end{array}$} \\
\hline & Foco no desenvolvimento de competências. & \\
\hline \multirow[b]{2}{*}{ TO } & $<<$ LITERAL >> & \multirow{2}{*}{$\begin{array}{l}\text { El: Direitos de aprendizagem / Campos de Experiências / Objetivos de aprendizagem } \\
\text { e desenvolvimento / Detalhamento dos objetivos de aprendizagem e desenvolvimento } \\
\text { / Sugestões de experiências. } \\
\text { EF: Campos de atuação / Unidade temática (Eixo) / Habilidades / Objetos de } \\
\text { conhecimento / Sugestões pedagógicas. }\end{array}$} \\
\hline & Foco no desenvolvimento de Competências e Habilidades. & \\
\hline
\end{tabular}

Fonte: Elaborado pela autora (2020)

* Novas habilidades criadas pelo estado. 


\section{ANEXOS}

ANEXO A - DECLARAÇÃO DE PARTICIPAÇÃO NA AUDIÊNCIA PÚBLICA DO CNE

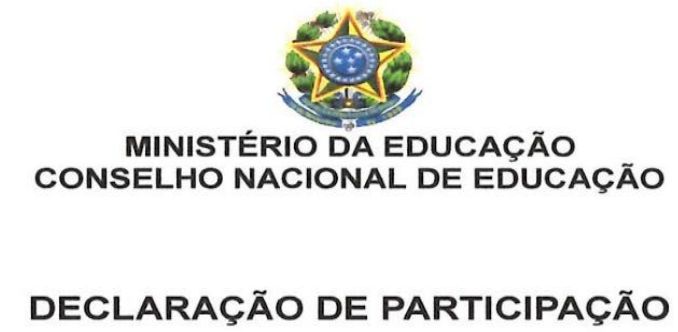

Declaro, para os devidos fins, que ALESSANDRA VALÉRIA DE PAULA participou da AUDIÊNCIA PÚBLICA SOBRE A BASE NACIONAL COMUM CURRICULAR - ENSINO MÉDIO, realizada pelo Conselho Nacional de Educação, no dia 14 de setembro de 2018, das 9h às 17h, em Brasília/DF.

\section{Andrer malaget \\ ANDREA MALAGUTTI \\ Secretária Executiva}

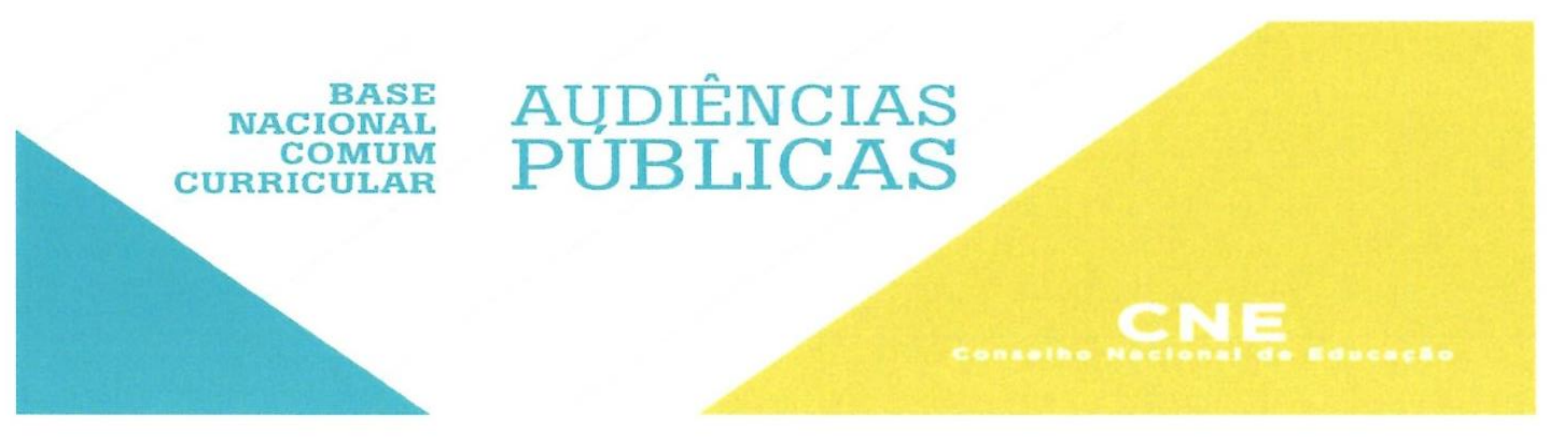


ANEXO B - E-MAIL DA SEDUC-RO

\section{SOBRE REFERENCIAL CURRICULAR}

1 mensagem

\section{OUVIDORIA SEDUC-RO <OUVIDORIA@SEDUC.RO.GOV.BR> TER, 19 DE MAI DE 2020 ÀS 12:28}

\section{PARA: ALESSANDRA VALERIA <ALEVPAULA@GMAIL.COM>}

Prezada Alessandra Valéria,

Ao retornarmos sua solicitação à Gerência de Formação, Capacitação Técnica e Pedagógica/GFCTP/SEDUC, foi nos confirmado que o Referencial Curricular do Estado de Rondônia de Educação Infantil e Ensino Fundamental, realmente foi homologado pela Resolução no 1233/2018/CEE/RO em 19/12/2018, sob o Processo no 120/2018-CEE/RO e Parecer no 003/2028-CEE/RO, porém com algumas orientações para serem ajustadas. Em razão de algumas transições decorrente do organograma da Secretaria de Estado da Educação para o exercício de 2019 em especial o Processo ํo 0029321021/2019/66 de tramitação de licitação para a contratação de empresa especializada em prestação de serviços de diagramação, revisão ortográfica e impressão, conforme condições, quantidades e exigências estabelecidas, os trabalhos ainda não foram concluídos. O Referencial Curricular do Estado de Rondônia em cumprimento aos itens $\mathbf{3}$ e $\mathbf{6}$ referente ao voto das redatoras constante no Parecer no 003/2028-CEE/RO, está com previsão de encaminhamento no dia 20 maio de 2020, para nova apreciação pelo Conselho Estadual de Educação do Estado de Rondônia (CEE/RO).

Assim, tão logo ocorra a apreciação e deliberação, poderemos atender Vossa Senhoria, com a versão preliminar, posto que só podemos considerar o Referencial Curricular do Estado de Rondônia pronto, após ter passado pelo processo de diagramação, revisão ortográfica pela empresa especializada e contratada para a prestação do serviço.

Att,

Edineide do Casal 


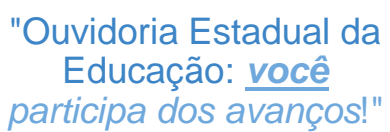

Ouvidoria Estadual da Educação

Secretaria de Estado da Educação de

Rondônia Alô Seduc 0800-647-3838 /

(69) 3216-5306 / 3216-5329

seduc.ro.gov.br

"Esta mensagem, incluindo seus anexos, podem conter informações privilegiadas e/ou de caráter confidencial, não podendo ser retransmitida sem autorização do remetente. Se você não é o destinatário ou a pessoa autorizada a recebê-la, informamos que seu uso, divulgação, cópia ou arquivamento são proibidos. Portanto, se você recebeu esta mensagem por engano, por favor, nos informe, respondendo imediatamente a este email e em seguida apague esta mensagem."

Livre de vírus. www.avast.com. 


\section{ANEXO C - E-MAIL DO MEC}

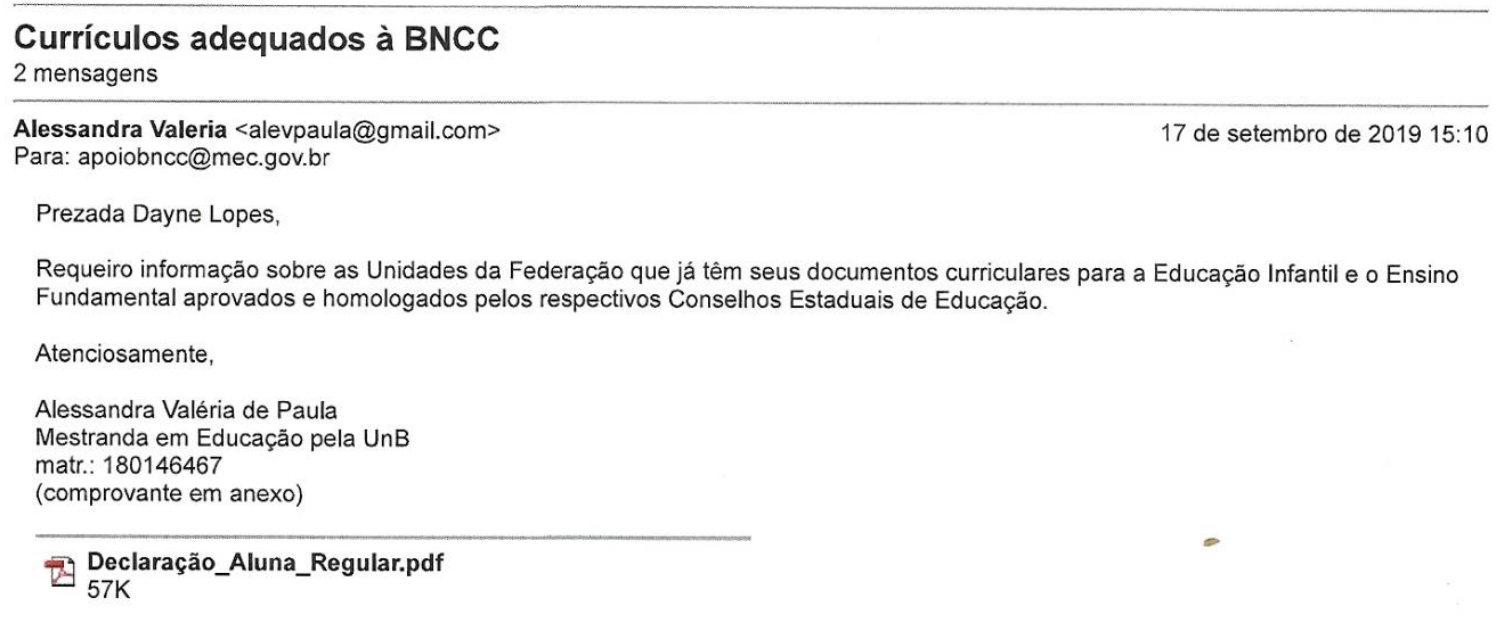

APOIO BNCC <apoiobncc@mec.gov.br>

18 de setembro de 2019 09:12

Para: Alessandra Valeria <alevpaula@gmail.com>

Prezada Alessandra,

Segue mapa atualizado com os Currículos aprovados pelos (Conselhos Estaduais de Educação - CEEs) da Educação Infantil e do Ensino Fundamental. Os Estados do Amazonas e Rio de Janeiro tiveram a versão final dos currículos estaduais entregues para os CEEs, para aprovação.

ATUALIZAÇOES.

\section{CURRICULOS APROVADOS}

Afrejelaboraço dos curticulos de educaço intarts

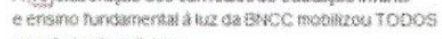
as estaces brasseirces

2 Ufs (estados e DF)

aprovarams

Ertados (AM \& $\&$ )

entregaram a versio

Curricular acs Conseltion

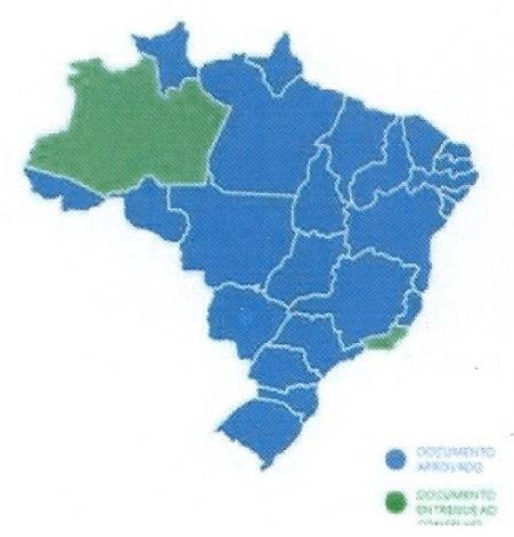

Caso precise de outros dados sobre a BNCC, sugere-se a pesquisa nos sites:

http://basenacionalcomum.mec.gov.br/

http://movimentopelabase.org.br/biblioteca/ 
$18 / 09 / 2019$

Gmail - Currículos adequados à BNCC

Atenciosamente,

Coordenação-Geral de Inovação e Interação com o Trabalho

Diretoria de Políticas e Regulação da Educação Básica

Secretaria de Educação Básica

Ministério da Educação

[Texto das mensagens anteriores oculto] 


\section{ANEXO D - RESPOSTA DO MEC AO PEDIDO DE INFORMAÇÃO SOBRE O CUSTO DA BNCC}

\section{Dados do Pedido}

Protocolo

Solicitante

Data de Abertura

Orgão Superior Destinatário

Orgão Vinculado Destinatário

Prazo de Atendimento

Situação

Status da Situação
23480008872202018

ALESSANDRA VALERIA DE PAULA

16/04/2020 17:08

MEC - Ministério da Educação

06/05/2020

Respondido

Órgão não tem competência para responder sobre o assunto

Forma de Recebimento da Resp Pelo sistema (com avisos por email)

Resumo

Detalhamento
Custo da Base Nacional Comum Curricular (BNCC) Para fins de pesquisa de mestrado, requeiro informação acerca do custo total ao MEC da Base Nacional Comum Curricular (BNCC), desde a elaboração, da implementação aos dias de hoje. Anexo minha declaração de aluna regular de mestrado. 
Dados da Resposta

Data de Resposta

Tipo de Resposta

Classificação do Tipo de

Resposta

Resposta

Responsável pela

Resposta

Chefe de Gabinete

Destinatário do Recurso

de Primeira Instância: Secretário de Educação Básica

Prazo Limite para

Recurso

$04 / 05 / 2020$

23/04/2020 18:21

Prezada Senhora, ainda nem ocorreram). (CONSED):

Atenciosamente,

Chefia de Gabinete

Secretaria de Educação Básica

Ministério da Educação
Órgão não tem competência para responder sobre o assunto

Cumprimentado-a cordialmente e em resposta à demanda registrada, informamos que o processo de implementação da BNCC se dá nos estados e municípios, e cada estado tem autonomia para conduzir esse processo.

Deste modo, o valor que deseja encontrar, chegará mais perto do real consultando estado por estado, pois o MEC fez (e faz) aos estados repasses de várias naturezas (Bolsas, PAR, eventos, etc) e não temos como precisar o que cada estado já gastou até agora (visto que o repasse já foi feito pelo MEC, mas tem ações que nos estados estão em andamento e outras que

Messe sentido, para obter as informações solicitadas, sugerimos contactar o Conselho Nacional de Secretários de Educação

(61)21958650 - consed@consed.org.br.

Classificação do pedido

Categoria do Pedido Educação

Subcategoria do Pedido Educação básica

Número de Perguntas 1 


\section{Histórico do Pedido}

\begin{tabular}{|l|l|l|}
\hline Data do evento & \multicolumn{1}{|c|}{ Descrição do evento } & \multicolumn{1}{c|}{ Responsável } \\
\hline 16/04/2020 17:08 & $\begin{array}{l}\text { Pedido Registrado para para o } \\
\text { Órgão MEC - Ministério da } \\
\text { Educação }\end{array}$ & SOLICITANTE \\
\hline 23/04/2020 18:21 & Pedido Respondido & MEC - Ministério da Educação \\
\hline 27/04/2020 18:09 & $\begin{array}{l}\text { Recurso de 1a. instância } \\
\text { registrado }\end{array}$ & SOLICITANTE \\
\hline 04/05/2020 18:47 & $\begin{array}{l}\text { Recurso de 1a. instância } \\
\text { respondido }\end{array}$ & MEC - Ministério da Educação \\
\hline
\end{tabular}

\section{Dados do Recurso de 1aㅗ Instância}

Órgão Superior Destinatário

Órgão Vinculado Destinatário

Data de Abertura

Prazo de Atendimento

Tipo de Recurso
MEC - Ministério da Educação

27/04/2020 18:09

$04 / 05 / 2020$

Outros

\section{Justificativa}

Prezado/a Senhor/a, Requeri o valor gasto pelo MEC com a Base Nacional Comum Curricular - BNCC (elaboração, implementação, ProBNCC, formação) e não obtive informação, sob a alegação de que há vários programas de repasse aos estados, bem como a sugestão de que eu interrogasse a todas as Unidades da Federação (UF). No entanto, o meu objeto de pesquisa de mestrado não se atém ao que cada UF dispendeu, mas sim, ao que o MEC investiu. Assim, requeiro à essa comissão recursal que considere minha indagação e atenda essa solicitação.

Respeitosamente, 


\section{Resposta ao Recurso de 1aㅡ Instância}

Data da Resposta

04/05/2020 18:47

Prazo para Disponibilizar Informação -

Tipo Resposta

Indeferido

Justificativa

Prezada Senhora,

Cumprimentado-a cordialmente e em resposta ao recurso interposto, comunico seu indeferimento, reiterando a resposta anteriormente fornecida, esclarecendo que o processo de implementação da BNCC se dá nos estados e municípios, e cada estado tem autonomia para conduzir esse processo. Deste modo, o valor que deseja encontrar, chegará mais perto do real consultando estado por estado, pois o MEC fez (e faz) aos estados repasses de várias naturezas (Bolsas, PAR, eventos, etc) e não temos como precisar o que cada estado já gastou até agora (visto que o MEC tem feito repasses, mas tem ações que nos estados estão em andamento e outras que ainda não ocorreram).

Em resumo: não dispomos da informação consolidada nos moldes do interesse de pesquisa da demandante, visto que a etapa de implementação é o que corresponde às ações em curso "aos dias de hoje". Ou seja, em virtude do fato da Base Nacional Comum Curricular ainda estar em fase de implementação, conforme cronograma específico, as redes de ensino têm até 2020 para consolidar os seus referenciais curriculares da Educação Infantil e do Ensino Fundamental alinhados à BNCC, e até 2022 para implementação dos referenciais curriculares do Novo Ensino Médio, igualmente alinhados à BNCC, não temos o cálculo consolidado do "custo total ao MEC da Base Nacional Comum Curricular (BNCC)", pois o processo de implementação encontra-se em andamento. Para mais informações sobre as etapas da implementação, favor consultar os normativos referentes ao Programa de Apoio à Implementação da Base Nacional Comum Curricular (ProBNCC), presentes na Portaria MEC n 331/2018 (alterada pelas Portarias no 756/2019 e no 1371/2019).

Contudo, esclarecemos que as ações empreendidas no processo de implementação da BNCC, a saber, repasses de recursos via Plano de Ações Articuladas (PAR) para os estados e a concessão de bolsas às equipes estaduais, ambas ações no âmbito do ProBNCC, são de conhecimento público, só não estando ainda concluídas, visto que a previsão para a finalização da implementação da BNCC é para o ano de 2022.

Ademais, cabe esclarecer que, conforme orienta a Lei $\mathrm{n}^{\circ} 12.527$, de 18 de novembro de 2011 (Lei de Acesso à Informação - LAl), no seu inciso V, Art. 4: 
Art. 4ํㅜ Para os efeitos desta Lei, considera-se:

(...)

V - tratamento da informação: conjunto de ações referentes à produção, recepção, classificação, utilização, acesso, reprodução, transporte, transmissão, distribuição, arquivamento, armazenamento, eliminação, avaliação, destinação ou controle da informação.

Portanto, nos casos de solicitações que exijam trabalhos adicionais de análise, interpretação ou consolidação de dados ou informações, que é o caso em tela, ou seja, a informação a ser disponibilizada precisa

necessariamente passar por um processo de tratamento que, em razão de não possuirmos tal informação, esta DPD/SEB não tem condições para a sua disponibilização. Tendo em vista que a BNCC encontra-se em processo de implementação, e suas informações ainda encontram-se em "estado bruto", requerendo uma análise pormenorizada para se adequar ao pedido formulado, que no momento não é possível, sobretudo as informações financeiras.

Nesse sentido, por compreender que é inadequado oferecer dados em "estado bruto", ou seja incompletos e transitórios, como se conclusivos fossem, nos reportamos ao inciso III do Art. 13 do Decreto $n^{\circ} 7.724 / 12$, que regulamenta a LAI, o qual orienta que:

Art. 13. Não serão atendidos pedidos de acesso à informação:

III - que exijam trabalhos adicionais de análise, interpretação ou consolidação de dados e informações, ou serviço de produção ou tratamento de dados que não seja de competência do órgão ou entidade.

Sendo assim, a parte inicial do inciso III trata da informação solicitada que não existe no formato especificado pelo requerente, todavia a sua produção é possível, contudo, conforme relatado acima, o contexto no qual se encontra a implementação da BNCC, ou seja, ainda não-concluída, impossibilita assim o tratamento, a consolidação dos dados e o seu respectivo oferecimento ao público e ao cidadão, em geral.

Atenciosamente, Secretário de Educação Básica

Ministério da Educação

Responsável pela Resposta

Destinatário do Recurso de $2^{\text {a }}$ Instância

Prazo Limite para Recurso
Secretária de Educação Básica

Ministro da Educação

$14 / 05 / 2020$ 